\title{
ESTRUTURAS DE CONTENÇÃO REFORÇADAS COM GEOSSINTÉTICOS
}

\author{
Emerson Oliveira Pedroso
}

Dissertação apresentada à Escola de Engenharia de São Carlos da Universidade de São Paulo, como parte dos requisitos para a obtenção do título de Mestre em Geotecnia

ORIENTADOR: Prof. Dr. Benedito de Souza Bueno

São Carlos

2000 
Dedico este trabalho à minha família e a Deus. 


\section{AGRADECIMENTOS}

A Deus, por estar sempre ao meu lado dando muita força, amor e esperança. Sem a ajuda Dele nada seria possível.

Aos meus pais, Leônidas e Lycia, e meus irmãos, Lyene e Wander, pelo incentivo, orações e amor em todos os momentos.

Ao meu orientador, Prof. Dr. Benedito de Souza Bueno, por sua atenção, ajuda, amizade e excelente orientação que foram fundamentais para o bom desenvolvimento deste nosso trabalho.

Aos colegas de república: André (Xará), Douglas, Dudu, Fabão, Robson, Roger e Werley pela sincera amizade, pelas conversas nos momentos difíceis, pela companhia nas festas e pelas brincadeiras e piadas.

Aos amigos do Grupo de Oração Universitário da USP e aos amigos do JSC de Viçosa que continuam me incentivando na caminhada com Deus. Não poderia deixar de agradecer à Maju pela ajuda na minha vinda para São Carlos, pelos momentos que vivemos juntos e pela grande amizade que permaneceu.

A Ober pelo incentivo a esta pesquisa e financiamento do protótipo.

Ao engenheiro Silvio e ao mestre de obras José Roberto pela ajuda na construção do protótipo e pela realização das leituras da instrumentação.

A todos os funcionários e professores do Departamento de Geotecnia da EESC, especialmente ao técnico José Luís Guerra pela inestimável ajuda na construção dos medidores de recalque e deslocamentos horizontais e na realização dos ensaios.

Ao Ronaldo, funcionário da Engenharia Mecânica, pela ajuda na obtenção dos ímãs para fazer as placas magnéticas.

A todos os colegas do Departamento de Geotecnia. Em especial ao Luiz, Paulo Márcio, Sidnei e Rodrigo que me ajudaram na procura dos ímãs.

Ao CNPQ pela bolsa de estudo concedida. 


\section{SUMÁRIO}

LISTA DE FIGURAS................................................................... i

LISTA DE TABELAS..................................................................

LISTA DE ABREVIATURAS, SIGLAS E SÍMBOLOS................... vi

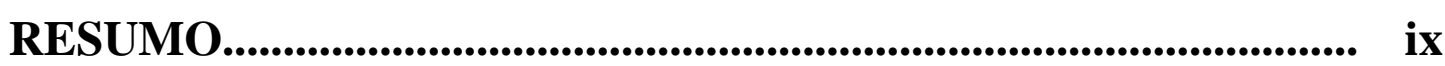

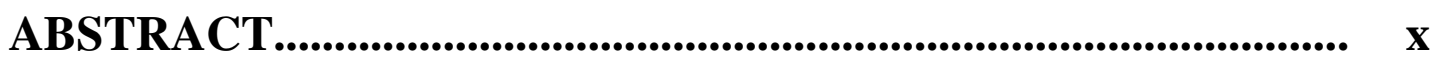

1 INTRODUÇÃO................................................................... 1

1.1 Trabalho proposto.............................................................................................. 2

1.2 Objetivos.................................................................................................. 2

1.3 Organização da dissertação...................................................................... 2

2 REVISÃO BIBLIOGRÁFICA.................................................. 4

2.1 Princípio de funcionamento de estruturas de contenção em solo reforçado 4

2.2 Métodos de dimensionamento................................... 5

2.2.1 Estabilidade externa..................................... 5

2.2.2 Estabilidade interna........................................ 6

2.2.3 Método de Mitchell \& Villet.................................. 7

2.2.4 Método de Jewell............................................ 10

2.2.5 Método de Leschinsky \& Perry.............................. 14

2.2.6 Método de Leschinsky \& Boedeker............................ 19

2.3 Fatores que influenciam no comportamento de estruturas de contenção reforçadas com geossintéticos. 
2.3.1 Rigidez da face.......................................... 24

2.3.1.1 Influência do empuxo ativado sobre a superfície da face..... 25

2.3.1.2 Resultados de ensaios em protótipos e modelos reduzidos.... 26

2.3.2 Tipo de solo.............................................. 28

2.3.2.1 Tipos de influência do solo no desempenho das estruturas.... 30

2.3.3 Tipo de inclusão............................................. 32

2.3.3.1 Tipo de influência da inclusão no desempenho das estruturas 32

2.3.4 Características geométricas da estrutura...................... 33

2.3.4.1 Influência da relação L/H no desempenho das estruturas.... 34

2.3.4.2 Influência dos arranjos das inclusões no desempenho das estruturas........................................... 34

2.3.5 Efeito da compactação......................................... 36

2.4 Utilização de MEF em estruturas em solo reforçado................. 37

3 MATERIAIS E MÉTODOS......................................... 39

3.1 Introdução........................................................ 39

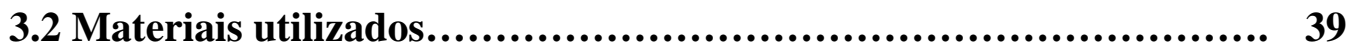

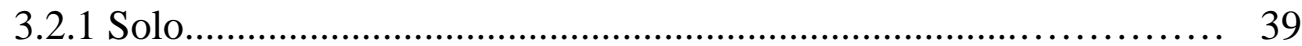

3.2.2 Geotêxtil................................................................ 42

3.3 Dimensionamento do protótipo........................................................ 42

3.4 Construção do protótipo...................................................................... 43

3.5 Instrumentação.................................................. 45

3.5.1 Instrumentação horizontal.......................................................... 45

3.5.2 Instrumentação vertical........................................................... 46

3.6 Modelagem numérica do protótipo.................................................. 47

4 APRESENTAÇÃO E DISCUSSÃO DOS RESULTADOS............ 50

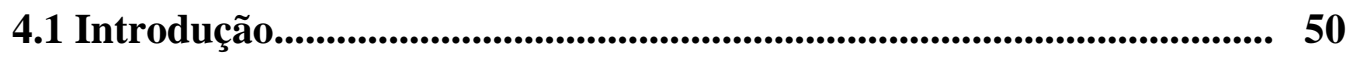

4.2 Resultados do protótipo.................................................................................... 50

4.2.1 Deslocamentos horizontais do protótipo......................... 50

4.2.2 Deslocamentos verticais do protótipo......................... 52

4.2.3 Resultados das tensões e deformações obtidas das simulações......... 54

4.2.4 Resultados das distribuições das forças de tração nas inclusões...... 55 
4.3 Análises paramétricas................................................................................... 56

4.3.1 Efeito do tipo de solo............................................................... 57

4.3.2 Efeito da rigidez da inclusão....................................................... 58

4.3.3 Efeito do tipo de arranjo....................................... 59

4.3.4 Forças de tração máximas nas inclusões.......................................... 60

4.3.5 Localização da superfície de ruptura............................................... 62

4.4. Casos de obras instrumentadas............................................................... 62

5 CONCLUSÕES E RECOMENDAÇÕES PARA PESQUISAS

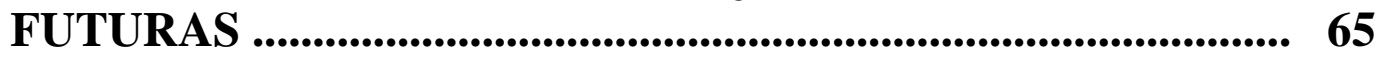

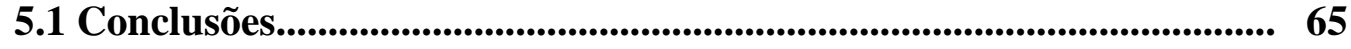

5.2 Recomendações para pesquisas futuras pesquisas.............................. 67

REFERÊNCIAS BIBLIOGRÁFICAS.............................68 


\section{LISTA DE FIGURAS}

FIGURA 2.1 - Modos de ruptura na análise da estabilidade externa 6

FIGURA 2.2 - Definição da zona ativa e resistente 6

FIGURA 2.3 - Maciço reforçado com geotêxtil e seu diagrama de empuxo 7

FIGURA 2.4 - Superfície de ruptura em cunha bilinear (JEWELL et al. apud $\begin{array}{ll}\text { SILVA, 1996) } & 10\end{array}$

FIGURA 2.5 - Ábaco para a determinação da constante $K_{\mathrm{Re} a}$ (JEWELL, 1991) 11

FIGURA 2.6 - Representação das zonas ativa e resistente e o comprimento de ancoragem $\left(L_{e}\right)$

FIGURA 2.7 - Análise da estabilidade externa (JEWELL, 1991) 14

FIGURA 2.8 - Reorientação da força de tração no reforço. 15

FIGURA 2.9 - Forças atuantes na cunha de ruptura e o polígono de forças (LESHCHINSKY \& PERRY, 1989)

FIGURA 2.10 - Inclinação da superfície de ruptura, $\theta_{c r}$, como uma função de: a) inclinação da força de reforço ( $\zeta)$; b) ângulo de atrito do solo $(\phi)$ (LESHCHINSKY \& PERRY, 1989)

FIGURA 2.11 - Determinação da extensão da superfície de ruptura (LESHCHINSKY \& PERRY, 1989)

FIGURA 2.12 - Resultante das forças de tração requeridas nos reforços (LESHCHINSKY \& PERRY, 1989)

FIGURA 2.13 - Espirais logarítmicas utilizadas no método de LESHCHINSKY \& BOEDEKER (1989) 
FIGURA 2.14 - Ábaco para a determinação da força de tração no reforço (LESHCHINSKY \& BOEDEKER, 1989)

FIGURA 2.15 - Ábacos para a definição da superfície de ruptura e o comprimento parcial de reforço $\left(l_{s j}\right)$ na zona ativa (LESHCHINSKY \& BOEDEKER, 1989)

FIGURA 2.16 - Verificação da estabilidade externa LESHCHINSKY \& BOEDEKER (1989)

FIGURA 2.17 - Ábacos para a determinação do comprimento total de reforço, $l_{j}$, verificando a estabilidade externa (LESHCHINSKY \& BOEDEKER, 1989)

FIGURA 2.18 - Ruptura progressiva iniciando a partir de uma ruptura compressional local do solo imediatamente atrás da superfície da estrutura (TATSUOKA, 1992)

FIGURA 2.19 - Os modelos A e B representam a distribuição da força de tração no reforço para uma estrutura em solo reforçado (TATSUOKA, 1992) 26

FIGURA 2.20 - Curvas granulométricas de alguns solos e a faixa granulométrica recomendada pela FHWA para a construção de estruturas em solo reforçado

FIGURA 2.21 - Forças de tração máximas ao longo da altura da estrutura (ADIB et al., 1990)

FIGURA 2.22 - Superfícies de ruptura linear e bilinear

FIGURA 2.23 - Posição da superfície de ruptura de acordo com a relação L/H (PORBAHA, 1998)

FIGURA 2.24 - Arranjos de reforços ensaiados (LANZ \& PALMEIRA, 1994)

FIGURA 2.25 - Estrutura em solo reforçado com faixa com menor grau de compactação

FIGURA 2.26 - Detalhe dos elementos da malha uilizando representação discreta (SILVA, 1998)

FIGURA 3.1 - Curva granulométrica do solo utilizado no protótipo 
FIGURA 3.2 - Curva de compactação do solo utilizado no protótipo 40

FIGURA 3.3 - Resultados dos ensaios triaxiais CD e do modelo hiperbólico 42

FIGURA 3.4 - Geometria do protótipo após o seu dimensionamento 43

FIGURA 3.5 - Colocação da primeira manta de geotêxtil 44

FIGURA 3.6 - Compactação da camada de solo com uma placa vibratória 44

FIGURA 3.7 - Planta e corte da instrumentação horizontal e vertical 45

FIGURA 3.8 - Execução da instrumentação horizontal dentro do maciço reforçado 46

$\begin{array}{lll}\text { FIGURA } 3.9 & \text { - Medidor de recalque } & 47\end{array}$

FIGURA 3.10 - Módulo de PVC com a placa magnética acoplada 47

FIGURA 3.11 - Malha de elementos finitos usada nas simulações do protótipo 48

FIGURA 3.12 - Lançamento e correção das duas primeiras camadas da malha 49

FIGURA 4.1 - Posição das barras de aço e placas magnéticas $\quad 50$

FIGURA 4.2 - Deslocamentos horizontais dentro da cunha 51

FIGURA 4.3 - Deslocamentos horizontais fora da cunha 51

FIGURA 4.4 - Deslocamentos horizontais ao longo do tempo dentro da cunha 52

FIGURA 4.5 - Deslocamentos horizontais ao longo do tempo fora da cunha 52

FIGURA 4.6 - Deslocamentos verticais dentro da cunha 53

FIGURA 4.7 - Deslocamento verticais fora da cunha 53

FIGURA 4.8 - Deslocamentos verticais ao longo do tempo dentro da cunha 53

FIGURA 4.9 - Deslocamento verticais ao longo do tempo fora da cunha 53

FIGURA 4.10 - Tensões verticais atuantes na estrutura de contenção 54

FIGURA 4.11 - Deformações cisalhantes máximas atuantes na estrutura de contenção $\quad 55$

FIGURA 4.12 - Distribuição das forças de tração e posição da superfície de ruptura 56

FIGURA 4.13 - Deslocamentos horizontais para alguns tipos de solos e inclusões 59

FIGURA 4.14 - Tipos de arranjos que serão analisados 59

FIGURA 4.15 - Deslocamentos horizontais para diferentes arranjos 60

FIGURA 4.16 - Forças de tração máximas ao longo da altura da estrutura 61

FIGURA 4.17 - Localizações das superfícies de ruptura para alguns tipos de solo e inclusões 
FIGURA 4.18 - Efeito do tipo de inclusão em obras instrumentadas 64

FIGURA 4.19 - Efeito do tipo de solo em obras instrumentadas. 


\section{LISTA DE TABELAS}

TABELA 2.1 - Fatores de redução para muros reforçados (KOERNER, 1994) 8

TABELA 2.2 - Características granulométricas de alguns solos 29

TABELA 3.1 - Características dos corpos de prova utilizados nos ensaios $\begin{array}{ll}\text { triaxiais } & 40\end{array}$

TABELA 3.2 - Parâmetros do modelo hiperbólico para o solo usado no protótipo 41

TABELA 3.3 - Propriedades do geotêxtil não tecido agulhado 42

TABELA 3.4 - Fatores de redução e fatores de segurança para a estabilidade 43 interna

TABELA 4.1 - Parâmetros do modelo hiperbólico dos solos usados na simulação 57

TABELA 4.2 - Análises paramétricas 57

TABELA 4.3 - Deslocamentos horizontais publicados na literatura 63 


\section{LISTA DE ABREVIATURAS, SIGLAS E SÍMBOLOS}

$b$ - largura da manta de reforço;

$B$ - espessura do membro transversal da geogrelha;

c - coesão do solo;

E - módulo de rigidez do geotêxtil;

$f_{d s}$ - coeficiente de deslizamento entre o solo e o reforço;

FHWA - Federal Highway Administration

$F S$ - fator de segurança.

$F S_{d i}$ - fator de redução quanto a danos de instalação

$F S_{c r}$ - fator de redução quanto à fluência

$F S_{d q}$ - fator de redução quanto à degradação química

$F S_{d b}$-fator de redução quanto à degradação biológica

$H$ - altura do maciço reforçado;

$k$ - coeficiente de interação solo-reforço;

$K_{a}$ - coeficiente de empuxo ativo;

$\mathrm{K}$ - número do módulo de rigidez do solo;

$\mathrm{K}_{\mathrm{b}}$ - número do módulo volumétrico utilizado no modelo hiperbólico;

$\mathrm{K}_{\mathrm{o}}$ - coeficiente de empuxo em repouso;

$\mathrm{K}_{\mathrm{ur}}$ - número do módulo de rigidez para o carregamento e descarregamento utilizado no modelo hiperbólico;

$L_{e}$ - comprimento de ancoragem;

$l_{e j}$ - comprimento de ancoragem; 
$L_{r}$ - comprimento inserido na zona ativa;

$l_{s j}$ - comprimento inserido na zona ativa;

$L_{R \min }$ - comprimento total mínimo;

m - expoente do módulo volumétrico utilizado no modelo hiperbólico;

$\mathrm{n}$ - expoente do módulo de rigidez utilizado no modelo hiperbólico;

$P$ - força solicitante no reforço pela zona ativa;

$P_{a r r}$ - resistência total ao arrancamento;

$P_{f}$ - parcela de resistência atritiva;

$P_{P}$ - parcela de resistência passiva;

$q$ - sobrecarga;

$\mathrm{R}_{\mathrm{f}}$ - Coeficiente de ruptura do modelo hiperbólico;

$S$ - espaçamento entre os elementos transversais da geogrelha;

$S_{h}$ - espaçamento horizontal entre os reforços;

$S_{v}$ - espaçamento vertical entre os reforços;

$t_{j}$ - força de tração solicitante em cada reforço;

$t_{1}$ - força de tração que solicita o primeiro reforço;

$t_{m 1}$ - força de tração no primeiro reforço;

$t_{m j}$ - força de tração na j-ésima camada;

$T_{u l t}$ - resistência à tração máxima, obtida do ensaio de tração não confinada;

$T_{m}$ - força de tração equivalente no primeiro reforço;

$y_{j}$ - altura da base até a posição do primeiro reforço;

$z$ - altura de solo acima do nível de reforço considerado;

$\alpha_{b}$ - fração das áreas dos elementos transversais da geogrelha que desenvolve resistência passiva;

$\alpha_{s}$ - fração sólida da área da geogrelha;

$\beta$ - ângulo de inclinação do talude;

$\delta$ - coeficiente de interação entre o solo e o reforço;

$\phi$ - ângulo de atrito do solo; 
$\phi_{m}$ - ângulo de atrito mobilizado do solo;

$\gamma$ - peso específico do solo;

$\sum t_{j}$ - resultante das forças de tração;

$\sigma_{b}$ - tensão horizontal nos elementos transversais da geogrelha;

$\sigma_{v}^{\prime}$ - tensão vertical sobre a geogrelha;

$\sigma_{v}$ - tensão vertical atuante no reforço;

$\theta$ - ângulo de inclinação entre a superfície de ruptura em cunha e a horizontal;

$\theta_{1}$ - ângulo de inclinação da primeira parte da cunha bilinear;

$\theta_{2}$ - ângulo de inclinação da segunda parte da cunha bilinear;

$\theta_{c r}$ - ângulo de inclinação crítico entre a superfície de ruptura em cunha e a horizontal;

$\zeta$ - ângulo de reorientação do reforço; 


\section{RESUMO}

PEDROSO, E. O. (2000). Estruturas de contenção reforçadas com geossintéticos. São Carlos, 2000. 74p. Dissertação (Mestrado) - Escola de Engenharia de São Carlos, Universidade de São Paulo.

Este trabalho apresenta a construção e instrumentação de uma estrutura de contenção reforçada com geotêxtil, com 4,0m de altura, construída na cidade de Nova Odessa-SP. A instrumentação consistiu em medir os deslocamentos horizontais e verticais com barras de aço e placas magnéticas, respectivamente. Além disso, foram realizadas simulações numéricas para comparar os resultados medidos e simulados do protótipo e avaliar o comportamento da estrutura para alguns tipos de solo, rigidez da inclusão e arranjos das inclusões. Pode-se concluir que os resultados medidos e simulados estão concordantes. Através das análises paramétricas concluiuse que aumentando-se a rigidez do solo reduz-se os deslocamentos horizontais da estrutura. Com o aumento na rigidez da inclusão obtém-se menores deslocamentos, no entanto, em solos muito rígidos esta redução é pouco significativa. As estruturas com maior número de reforços reduzem as tensões em cada inclusão e diminuem os deslocamentos horizontais da estrutura. As forças de tração máximas, mobilizadas nas inclusões, são maiores para solos menos rígidos. Alguns resultados de obras instrumentadas, encontrados na literatura, são apresentados e comparados com os medidos e simulados. Destas comparações concluiu-se que o tipo de solo é o fator que mais influencia no desempenho de estruturas de contenção reforçadas com geossintéticos.

Palavras-chave: estrutura de contenção; solo reforçado; geossintéticos; instrumentação. 


\section{ABSTRACT}

PEDROSO, E. O. (2000). Reinforced Retaining Structures with geosynthetics. São Carlos, 2000. 74p. Dissertação (Mestrado) - Escola de Engenharia de São Carlos, Universidade de São Paulo.

This work presents the construction and instrumentation of a geotextile reinforced retaining structure, with 4,0m height, built in the city of Nova Odessa-SP. The instrumentation consisted of measuring the horizontal and vertical displacements with steel bars and magnetic plates, respectively. Numeric simulations were accomplished to compare the measured and simulated results of the prototype and to evaluate the behavior of the structure for some soil types, reinforcement rigidity and different reinforcement layout. It was concluded that the measured and simulated results are in good agreement. The parametric analyses showed that the amount of horizontal displacements of the structure are reduced when the rigidity of the soil increases. Although smaller displacements are obtained when the rigidity of the inclusion is increased, in very rigid soils this reduction is not very significant. Structures with larger number of reinforcements reduce the stresses in each inclusion, decreasing the horizontal displacements of the structure. The maximum tensile forces mobilized in the inclusions, are larger for less rigid soils. Some case record results documented in the literature are presented and compared with the measured and simulated results obtained in this work. These comparisons allowed to conclude that the soil type is the most relevant factor in the performance of reinforced retaining structure with geosynthetics.

Keywords: retaining structures; reinforced soils; geosynthetics; instrumentation. 


\section{INTRODUÇÃO}

Há, hoje em dia, uma série de opções viáveis para se estabilizar taludes de aterros. Dentre as técnicas mais atrativas destacam-se as em solo reforçado. As estruturas em solos reforçados são construídas com camadas horizontais de solo compactado intercaladas por camadas de geossintéticos (geotêxteis ou geogrelhas). A estrutura pode ou não possuir uma face rígida, entretanto, ela não é necessária em termos estruturais. Contudo, a face rígida é importante para evitar erosão, vandalismo e dispor de uma agradável estética. O desempenho destas estruturas depende da interação entre as inclusões e o solo. É desta interação que o sistema reforçado gera condições para garantir sua estabilidade.

As estruturas de contenção em solo reforçado, especialmente aquelas de 3 a $6 \mathrm{~m}$ de altura, são de uso freqüentes em várias situações práticas de engenharia, como na execução de platôs para implantação de edificações, em cortes e aterros de estradas, em regularizações de margens de rios, em desníveis gerados para a construção de trevos e encontros de viadutos, entre outros. Estas estruturas têm vantagens de apresentar soluções mais econômicas, simples e de fácil e rápida execução, em relação às estruturas convencionais de contenção. No entanto, apesar de suas inúmeras vantagens, no Brasil, ainda são poucas as obras executadas com essa técnica. A grande maioria das estruturas de contenção de 3 a $6 \mathrm{~m}$ de altura são ainda executadas através das soluções convencionais.

Dentro deste contexto, nota-se a necessidade de pesquisa e difusão de experiências desta técnica para que ela possa ser usada com mais frequiência. Além disso, há uma grande necessidade de aumentar o entendimento a respeito da influência de fatores como: tipo de solo, tipo de inclusão, rigidez da face, processo 
construtivo, efeito da compactação, arranjos das inclusões, entre outros, no comportamento de estruturas de contenção em solo reforçado.

\subsection{Proposta de Pesquisa}

Este trabalho descreve a construção e instrumentação de uma estrutura de contenção reforçada com geotêxtil com $4 \mathrm{~m}$ de altura, construída na cidade de Nova Odessa no Estado de São Paulo. Nela foram instaladas barras de aço e placas magnéticas, dentro do maciço reforçado, para monitorar os deslocamentos horizontais e verticais, respectivamente. Além disto, foram realizadas análises paramétricas por meio de um programa de elementos finitos. Nestas análises foram utilizados o solo e o reforço do protótipo e, também, outros tipos de solo, reforço e arranjo de reforços descritos na literatura. Finalmente, foram apresentados alguns resultados de obras instrumentadas publicados na literatura.

\subsection{Objetivos}

O presente trabalho tem como objetivo comparar os resultados dos deslocamentos medidos (pela instrumentação) e simulados (pelo programa de elementos finitos) em uma estrutura de contenção em solo reforçado com geotêxtil. Além disto, foram realizadas análises paramétricas para verificar a influência do tipo de solo, tipo de inclusões e arranjos das inclusões nos deslocamentos horizontais da estrutura, nas forças de tração máximas mobilizadas nas inclusões e na localização da superfície de ruptura.

\subsection{Organização da dissertação}

O presente trabalho está dividido em cinco capítulos. O primeiro apresenta uma introdução geral sobre estruturas de contenção reforçadas com geossintéticos, a descrição do trabalho proposto e seus objetivos. O segundo capítulo apresenta uma revisão bibliográfica mostrando o princípio de funcionamento de estruturas de 
contenção em solos reforçados, métodos de dimensionamento, os principais fatores que influenciam o comportamento de estruturas de contenção em solos reforçados e a utilização do método dos elementos finitos (MEF) em estruturas em solo reforçado. O capítulo terceiro descreve os ensaios realizados no solo utilizado na execução do protótipo, os detalhes da instrumentação horizontal e vertical e, também, a modelagem numérica do protótipo. O quarto capítulo apresenta e discute os resultados dos deslocamentos medidos pela instrumentação horizontal e vertical; os resultados das análises paramétricas e alguns resultados de instrumentação de obras publicados na literatura. O quinto capítulo apresenta as conclusões do presente trabalho e as recomendações para futuras pesquisas. 


\section{REVISÃO BIBLIOGRÁFICA}

\subsection{Princípio de funcionamento de estruturas de contenção em solo reforçado}

As estruturas em solos reforçados caracterizam-se pela associação de dois materiais com comportamentos mecânicos distintos: o solo, que pode apresentar resistências à compressão e ao cisalhamento relativamente elevadas, e o geossintético, que possui elevada resistência à tração. O princípio fundamental do comportamento mecânico destas estruturas caracteriza-se pelo desenvolvimento de tensões de tração no reforço através da interação com o solo ao longo do seu comprimento. A transferência de tensões entre o solo e o reforço, no caso mais geral, envolve dois mecanismos principais: a atrito e a resistência passiva do solo. As estruturas reforçadas com geotêxteis, no entanto, são sistemas puramente atritivos, ou seja, não há qualquer mobilização de resistência passiva do solo. Somente as estruturas reforçadas com geogrelhas podem possuir resistência passiva e atritiva. Por isto é importante conhecer os dois sistemas de transferência de tensões pois eles podem atuar ao mesmo tempo em estruturas de contenção reforçadas com geogrelhas.

Para apresentar um bom desempenho, as estruturas em solos reforçados devem satisfazer duas necessidades básicas. A primeira é que ocorram deslocamentos no maciço suficientes para mobilizar a resistência à tração do reforço e a resistência ao cisalhamento do solo. A segunda é que os movimentos da estrutura, ou seja, deslocamentos laterais da face e os recalques sejam limitados, de forma a garantir os requisitos de sua utilização. Em sistemas que utilizam reforços com elevados 
módulos de rigidez, como as geogrelhas, os seus deslocamentos laterais estão quase sempre dentro dos limites de utilização. Entretanto, quando se utilizam reforços com baixos módulos, como é o caso dos geotêxteis, deformações significativas são necessárias para a mobilização de forças de tração nos reforços. Desta forma, em maciços reforçados com geotêxteis, os valores das deformações e das forças mobilizadas nos reforços a elas associadas, constituem critério relevante de projeto, podendo assumir papel preponderante sobre os critérios de ruptura.

\subsection{Métodos de dimensionamento}

Os métodos de dimensionamento mais amplamente estudados são os baseados na análise por equilíbrio limite. Estes métodos baseiam-se no equilíbrio estático de uma massa de solo que se comporta como um corpo rígido, na iminência da ruptura.

Esses métodos exigem pouco esforço de cálculo e não fornecem qualquer informação sobre as deformações da estrutura, uma vez que somente as tensões são necessárias para o cálculo dos fatores de segurança contra a ruptura. Entretanto, para analisar as condições de trabalho deve-se levar em conta a compatibilidade de deformações entre os materiais constituintes, introduzindo no cálculo condições adicionais que garantam esta compatibilidade.

A análise da estabilidade é dividida em duas etapas, ou seja, verificação da estabilidade externa e da estabilidade interna.

\subsubsection{Estabilidade externa}

A estabilidade externa, assim como a das estruturas convencionais de contenção, pressupõe que o maciço reforçado atue como um corpo rígido (Figura 2.1).

A verificação da estabilidade externa da estrutura é feita segundo quatro mecanismos clássicos de ruptura: a) deslizamento ao longo da base da estrutura reforçada; b) tombamento em torno do pé da estrutura; c) ruptura do solo de fundação e d) ruptura global por uma superfície envolvendo todo o maciço reforçado. 


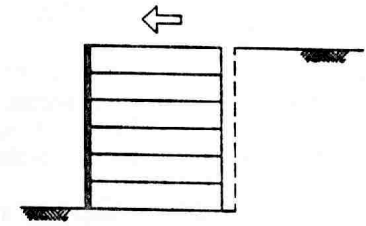

(a) Escorregamento por um plano preferencial

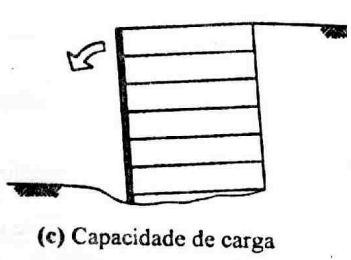

(c) Capacidade de carga

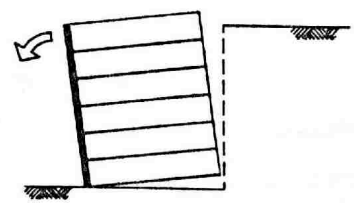

(b) Tombamento

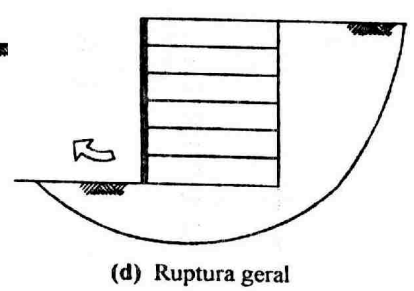

FIGURA 2.1 - Modos de ruptura na análise da estabilidade externa (SILVA, 1996).

\subsubsection{Estabilidade interna}

Os métodos baseados na análise por equilíbrio limite separam o maciço reforçado em duas regiões denominadas zonas ativa e resistente (Figura 2.2). Estas zonas são definidas por superfícies potenciais de ruptura, que podem possuir várias formas conforme o método analisado. Alguns métodos de análise admitem que a superfície potencial de ruptura seja plana e inclinada de $\left(45^{\circ}+\phi / 2\right)$ com a horizontal, passando pela sua base. Ou seja, as deformações horizontais do maciço reforçado permite que o solo atinja um estado de plastificação de Rankine. JONES (1990) mostra que para o maciço atingir a condição ativa, é necessário que a estrutura se deforme lateralmente o equivalente a $1 \%$ da sua altura.

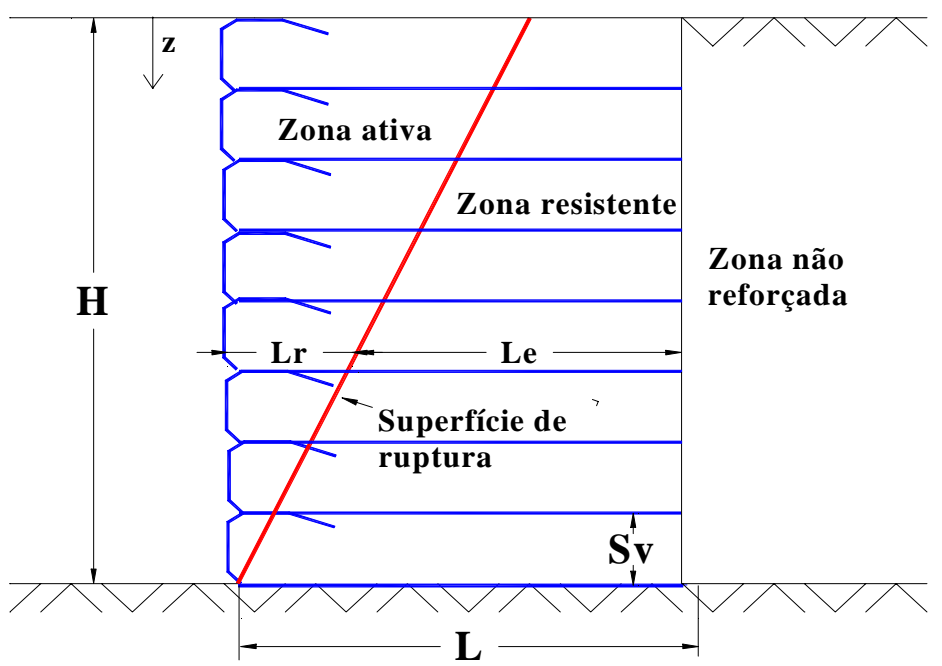

FIGURA 2.2 - Definição da zona ativa e resistente. 
A análise da estabilidade interna, de uma estrutura de contenção reforçada com geossintéticos, consiste em verificar a ruptura e o arrancamento de cada reforço no interior do maciço. A seguir serão descritos alguns métodos de análise da estabilidade interna baseados na análise por equilíbrio limite. As principais diferenças entres estes métodos são a forma adotada para a superfície de ruptura e o modo de obtenção da força de tração mobilizada no reforço (MITCHELL \& VILLET, 1987).

\subsubsection{Método de Mitchell \& Villet}

Este método foi originalmente desenvolvido para o cálculo da estabilidade interna de maciços reforçados por fitas metálicas, sendo posteriormente adaptado para maciços reforçados com geotêxteis (MITCHELL \& VILLET, 1987).

Admite-se que o solo atinja o estado de plastificação de Rankine, ou seja, a superfície hipotética de ruptura é plana e orientada segundo um ângulo de $\left(45^{\circ}+\phi / 2\right)$ com a horizontal. Disto resulta que a distribuição de empuxo, no maciço reforçado, é admitida linearmente crescente com a profundidade (Figura 2.3).

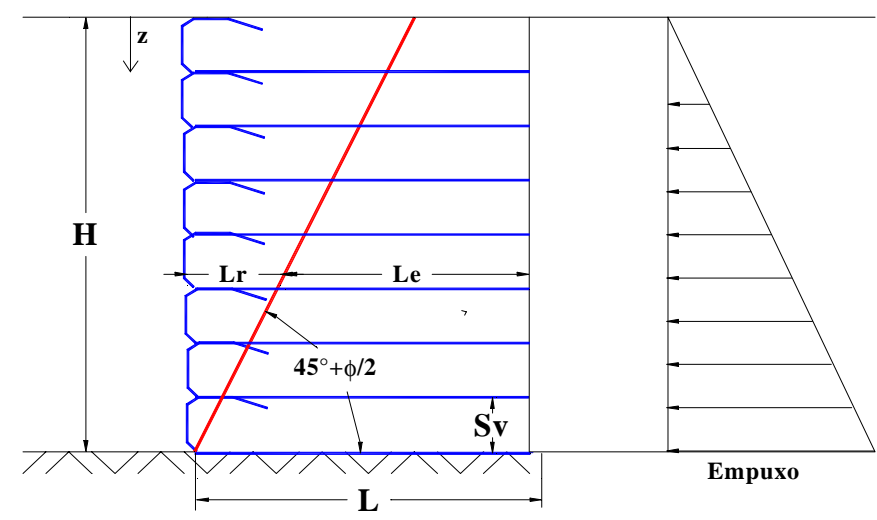

FIGURA 2.3 - Maciço reforçado com geotêxtil e seu diagrama de empuxo.

\subsubsection{Estabilidade interna}

A estabilidade interna é verificada pelo método de equilíbrio local, em que cada camada de reforço é analisada de forma independente. No cálculo da estabilidade interna, duas condições devem ser verificadas: a) ruptura do reforço e b) 
arrancamento do reforço. A análise da estabilidade interna fornece como resultados o espaçamento vertical e o comprimento das camadas de reforço.

\section{a) Ruptura do reforço}

O fator de segurança quanto à ruptura do reforço, em cada camada, é a relação entre a força de tração admissível do geotêxtil e a força de tração gerada no geotêxtil pelo maciço. Esta relação é mostrada pela eq. (2.1). A força admissível é dada pela eq.(2.2).

$$
\begin{aligned}
F S & =\frac{T_{a d m}}{k_{a} \cdot \gamma \cdot z \cdot S_{v} \cdot S_{h}} \\
T_{a d m} & =\frac{T_{u l t}}{F S_{d i} \cdot F S_{c r} \cdot F S_{d q} \cdot F S_{d b}}
\end{aligned}
$$

onde: $k_{a}$ - coeficiente de empuxo ativo;

$\gamma$ - peso específico do aterro reforçado;

$z$ - altura de solo acima do nível de reforço considerado (Figura 2.3);

$S_{v}$ - espaçamento vertical entre as camadas de reforços;

$S_{h}$ - espaçamento horizontal entre as camadas de reforços;

$T_{u l t}$ - resistência à tração máxima, obtida do ensaio de tração não confinada;

Os fatores de redução utilizados para determinar a força de tração admissível do reforço estão apresentados na Tabela 2.1.

TABELA 2.1- Fatores de redução para maciços reforçados (KOERNER, 1994).

\begin{tabular}{|c|c|c|}
\hline Tipo de fator de redução da resistência à tração & Símbolos & Valores \\
\hline Fator de redução quanto a danos de instalação & $F S_{d i}$ & 1,1 a 2,0 \\
\hline Fator de redução quanto à fluência & $F S_{c r}$ & 2,0 a 4,0 \\
\hline Fator de redução quanto à degradação química & $F S_{d q}$ & 1,0 a 1,5 \\
\hline Fator de redução quanto à degradação biológica & $F S_{d b}$ & 1,0 a 1,3 \\
\hline
\end{tabular}


MITCHELL \& VILLET (1987) propõem um coeficiente de segurança quanto à ruptura do reforço variando entre 1,3 a 1,5. Com isto, obtém-se o espaçamento vertical da estrutura de contenção pela eq. (2.3).

$$
S_{v}=\frac{T_{a d m}}{F S \cdot k_{a} \cdot \gamma \cdot z}
$$

\section{b) Arrancamento do reforço}

A análise do arrancamento do reforço tem como objetivo fornecer o comprimento total da inclusão, que pode ser dividido em duas parcelas: o comprimento inserido na zona ativa e o comprimento de ancoragem. A definição destas parcelas irá depender do mecanismo de ruptura adotado. Para este método o comprimento $L_{r}$, inserido na zona ativa, pode ser obtido pela eq. (2.4).

$$
L_{r}=(H-z) \cdot \operatorname{tg}\left(45^{0}-\frac{\phi}{2}\right)
$$

onde: $H$ - altura do maciço reforçado;

$z$ - altura de solo acima do nível de reforço considerado (Figura 2.3);

MITCHELL \& VILLET (1987) propõem um coeficiente de segurança quanto ao arrancamento no intervalo de 1,50 a 1,75. Com isto, pode-se determinar o comprimento de ancoragem $\left(L_{e}\right)$ em cada inclusão pela eq. (2.5). No entanto, o comprimento de ancoragem mínimo deverá ser de 1,0m.

$$
L_{e}=\frac{k_{a} \cdot \gamma \cdot z \cdot S_{v} \cdot F S}{2 \cdot \gamma \cdot z \cdot \tan (\delta)}
$$

onde: $\delta$ - é o coeficiente de atrito entre o solo e a inclusão;

O comprimento total do reforço é definido pela soma de $L_{r}$ e $L_{e}$. 


\subsubsection{Método de JEWELL}

O método de análise da estabilidade interna proposto por JEWELL et al* apud SILVA (1996) foi concebido para aterros reforçados com geogrelha. Posteriormente, o método foi revisado por JEWELL (1991) que propõe alterações no mecanismo de interação solo-reforço, na geometria da superfície de ruptura e no equilíbrio estático. Estas alterações permitiram que este método fosse, também, usado para estruturas reforçadas com faces verticais.

A superfície potencial de ruptura se desenvolve segundo uma cunha bilinear (Figura2.4). Ela é encontrada através de uma pesquisa iterativa, em que se variam os ângulos $\theta 1, \theta 2$ e o ponto (Xn,Yn), até se obter o fator de segurança mínimo.

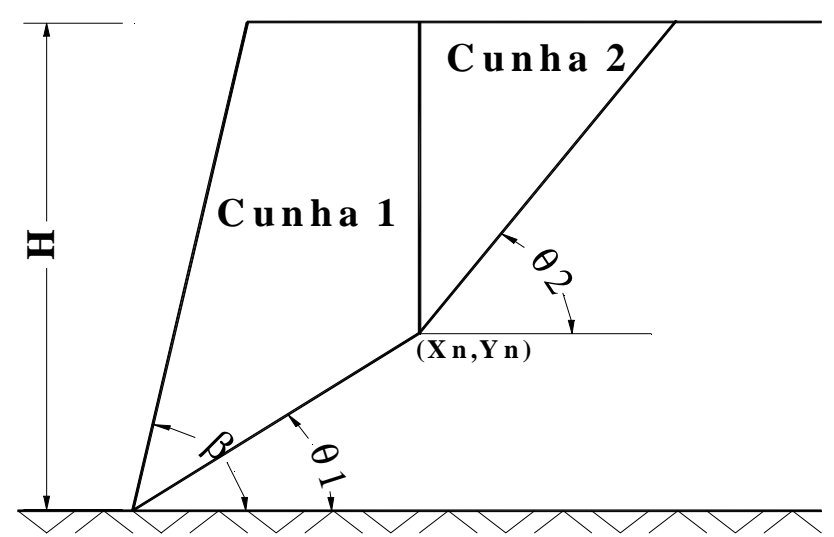

FIGURA 2.4 - Ruptura em cunha bilinear (JEWELL et al* apud SILVA, 1996).

\section{a) Ruptura do reforço}

A verificação da ruptura do reforço consiste em determinar o espaçamento vertical entre os reforços através da eq. 2.6. A constante $\left(K_{\operatorname{Re} q}\right)$ é determinada através da Figura 2.5. A força de tração admissível $\left(T_{a d m}\right)$ juntamente com os fatores de reduções são iguais aos definidos no item 2.2.3.1.

$$
S_{v}=\frac{T_{a d m}}{\gamma \cdot H \cdot K_{\operatorname{Re} q}}
$$

\footnotetext{
* JEWELL, R.A; PAINE, N.; WOODS, R.I. (1984). Design methods for steep reinforced embakments. In: Polymer Grid Reinforcement, London, Prooceedings, p. 18-30 apud SILVA, L.C.R. (1996). Análise do comportamento de muros reforçados em condições de trabalho. São Paulo. 202p. Dissertação (Mestrado) - Universidade de São Paulo.
} 


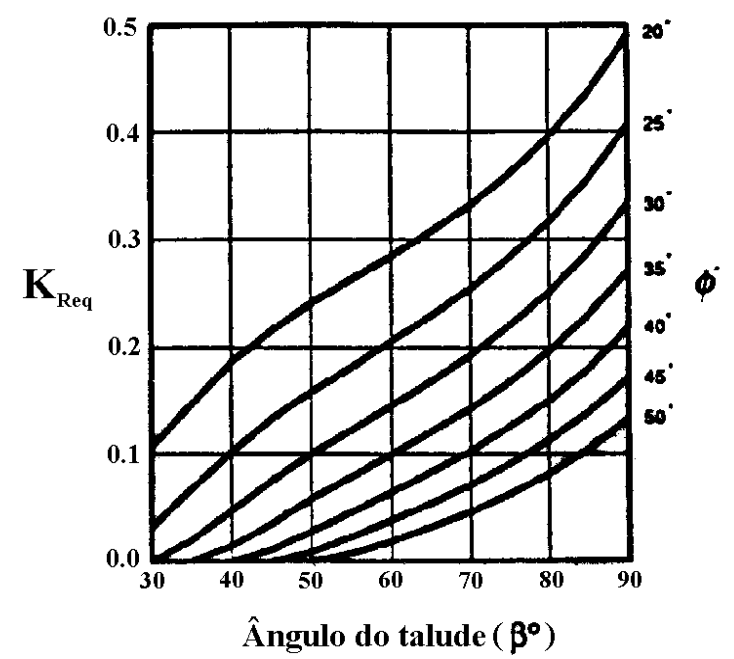

FIGURA 2.5 - Ábaco para a determinação da constante $K_{\operatorname{Re} q}$ (JEWELL,1991).

\section{b) Arrancamento do reforço}

O reforço deve possuir um comprimento tal que esteja suficientemente ancorado no solo de forma a resistir aos esforços de tração provenientes da zona ativa (Figura 2.6). Para verificar a estabilidade contra o arrancamento do reforço é preciso determinar a resistência total ao arrancamento $\left(P_{a r r}\right)$, dada pela eq. 2.7 , e a força solicitante fornecida pela eq. 2.8.

$$
\begin{aligned}
& P_{\text {arr }}=P_{f}+P_{P} \\
& P=K_{\operatorname{Re} q} \cdot \gamma \cdot z \cdot S_{v}
\end{aligned}
$$

onde: $P_{a r r}$ - resistência total ao arrancamento;

$P_{f}$ - parcela de resistência atritiva;

$P_{P}$ - parcela de resistência passiva;

$P$ - força solicitante no reforço pela zona ativa;

A parcela de resistência devido ao atrito na interface solo-reforço é dada pela eq. (2.9).

$$
P_{f}=2 \cdot L_{e} \cdot b \cdot \gamma \cdot z \cdot \alpha_{s} \cdot \tan \delta
$$


onde: $L_{e}$ - comprimento de ancoragem;

$b$ - largura da manta de reforço;

$\alpha_{s}$ - é a fração sólida da área da geogrelha (no caso de mantas de geotêxteis, $\alpha_{s}=1$ );

$\delta$ - coeficiente de interação entre o solo e o reforço;

A parcela de resistência passiva que se desenvolve em frente aos elementos transversais da geogrelha é dada pela eq. (2.10). O coeficiente de capacidade de carga pode ser calculado pela eq. (2.11).

$$
\begin{aligned}
& P_{P}=L_{e} \cdot b \cdot \gamma \cdot z \cdot\left(\frac{\sigma_{b}}{\sigma_{v}}\right)\left(\frac{B}{S}\right) \alpha_{b} \\
& \frac{\sigma_{b}^{\prime}}{\sigma_{v}^{\prime}}=\tan \left(\frac{\pi}{4}+\frac{\phi}{2}\right) \exp \left(\left(\frac{\pi}{2}+\phi\right) \tan \phi\right)
\end{aligned}
$$

onde: $\sigma_{b}$ - tensão horizontal nos elementos transversais da geogrelha;

$\sigma_{v}^{\prime}$ - tensão vertical sobre a geogrelha;

$S$ - espaçamento entre os elementos transversais da geogrelha;

$B$ - espessura do membro transversal da geogrelha;

$\alpha_{b}$ - fração das áreas dos elementos transversais da geogrelha que desenvolve resistência passiva;

Combinando-se os termos das equações (2.9) e (2.10) chega-se a uma expressão geral que fornece a resistência total ao arrancamento que é dada pela eq.(2.12).

$$
P_{a r r}=L_{e} \cdot b \cdot \gamma \cdot z \cdot\left(2 \cdot \alpha_{s} \cdot \tan \delta+\left(\frac{\sigma_{b}^{\prime}}{\sigma_{v}}\right)\left(\frac{B}{S}\right) \alpha_{b}\right)
$$

Para se garantir a estabilidade contra o arrancamento do reforço é preciso que a resistência total ao arrancamento $\left(P_{a r r}\right)$, dada pela eq. (2.12), seja maior ou igual à força solicitante da zona ativa $(P)$, dada pela eq. (2.8). Desta forma, encontra-se o comprimento de ancoragem $\left(L_{e}\right)$, dado pela eq. (2.13). 


$$
L_{e}=\frac{P}{b . \gamma \cdot z \cdot\left(2 \cdot \alpha_{s} \cdot \tan \delta+\left(\frac{\sigma_{b}^{\prime}}{\sigma_{v}^{\prime}}\right)\left(\frac{B}{S}\right) \alpha_{b}\right)}
$$

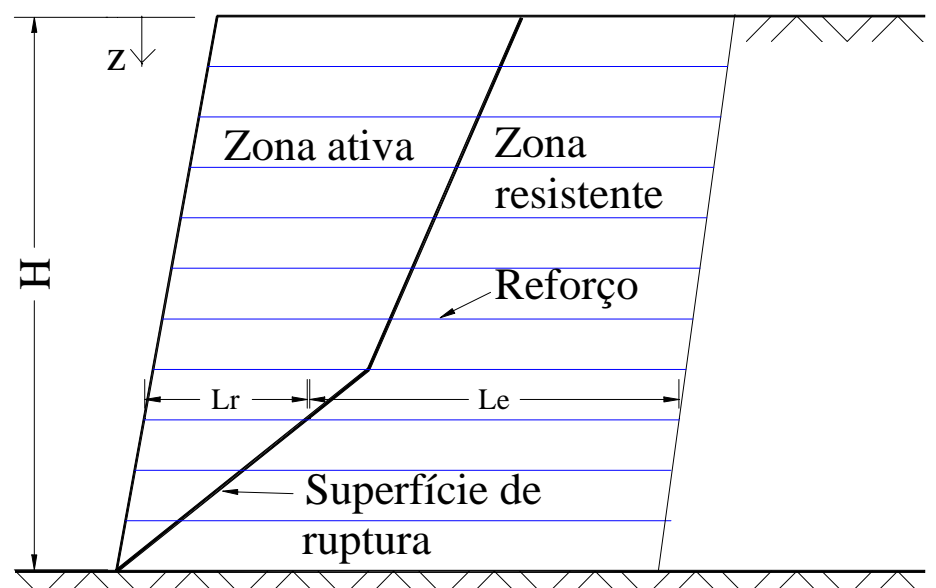

FIGURA 2.6 - Representação das zona ativa e resistente juntamente com o comprimento inserido na zona ativa $\left(L_{r}\right)$ e o de ancoragem $\left(L_{e}\right)$.

Além da análise da estabilidade externa que é verificada considerando-se os mecanismos clássicos mostrados no item 2.2.1 verifica-se também a possibilidade de deslizamento de um bloco de solo sobre cada camada de reforço, como mostra a Figura 2.7. Com isto, determina-se o comprimento de reforço de tal forma que a força de deslizamento $\left(P_{d e s}\right)$, dada pela eq. (2.14), seja menor ou igual à $\left(T_{a d m}\right)$. Assim, o comprimento mínimo ( $\left.L_{R \min }\right)$ é dado pela eq. (2.15).

$$
\begin{aligned}
& P_{d e s}=f_{d s} \cdot \gamma \cdot z \cdot b \cdot \tan \phi \\
& L_{R m i m}=\frac{T_{a d m}}{f_{d s} \cdot \gamma \cdot z \cdot b \cdot \tan \phi}
\end{aligned}
$$

O coeficiente de deslizamento $\left(f_{d s}\right)$ pode ser calculado pela eq. (2.16) proposta por JEWELL (1991).

$$
f_{d s}=\alpha_{s} \cdot \frac{\tan \delta}{\tan \phi}+\left(1-\alpha_{s}\right)
$$


Alternativamente, os valores do coeficiente de deslizamento $\left(f_{d s}\right)$ podem ser medidos diretamente através de ensaios de arrancamento e de cisalhamento direto do solo sobre o reforço.

A Figura 2.7 mostra a análise da estabilidade externa através do deslizamento de um bloco de solo sobre cada reforço.

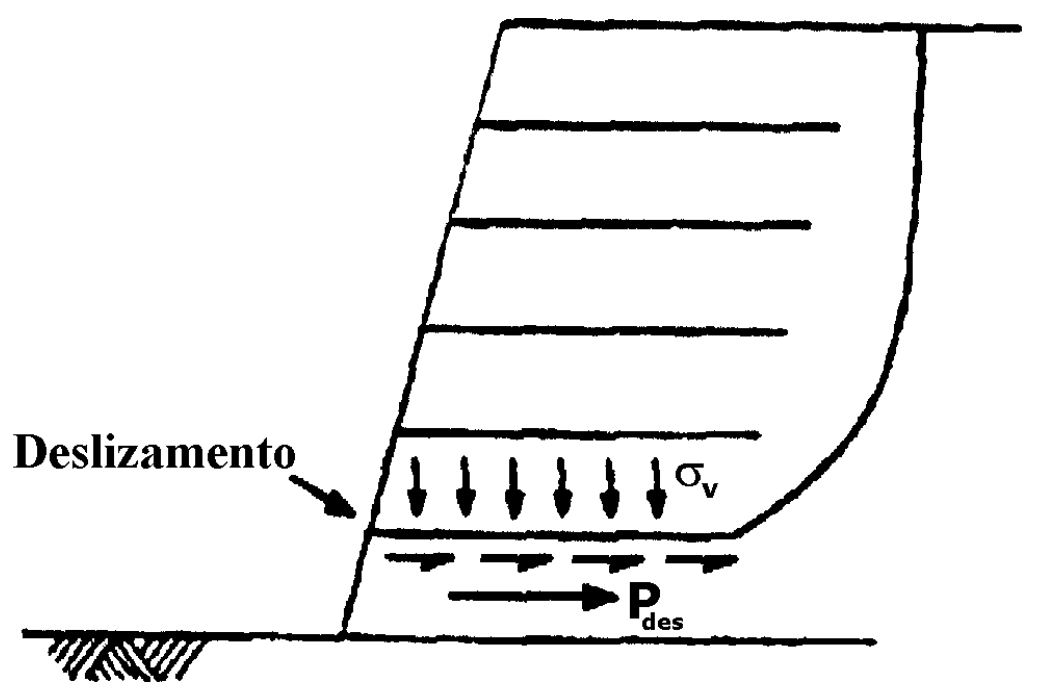

FIGURA 2.7 - Análise da estabilidade externa (JEWELL, 1991).

O comprimento final do reforço será o maior entre as análises da estabilidade interna e externa descritas anteriormente.

\subsubsection{Método de Leshchinsky \& Perry}

Um importante aspecto de projeto de uma estrutura reforçada com geossintético é especificar o comprimento de reforço necessário para que esta estrutura seja segura e econômica. Preocupando em otimizar o comprimento de reforço, LESHCHINSKY \& PERRY (1989) desenvolveram um método de dimensionamento que leva em conta a reorientação do reforço, na superfície de ruptura, quando a sua resistência à tração for mobilizada pelo deslocamento do maciço. Eles observaram que o reforço não permanece na direção horizontal ao longo do processo de interação, devido à pouca rigidez do geossintético, mas sofre uma reorientação com inclinação $(\zeta$ ), mostrada na Figura 2.8. 


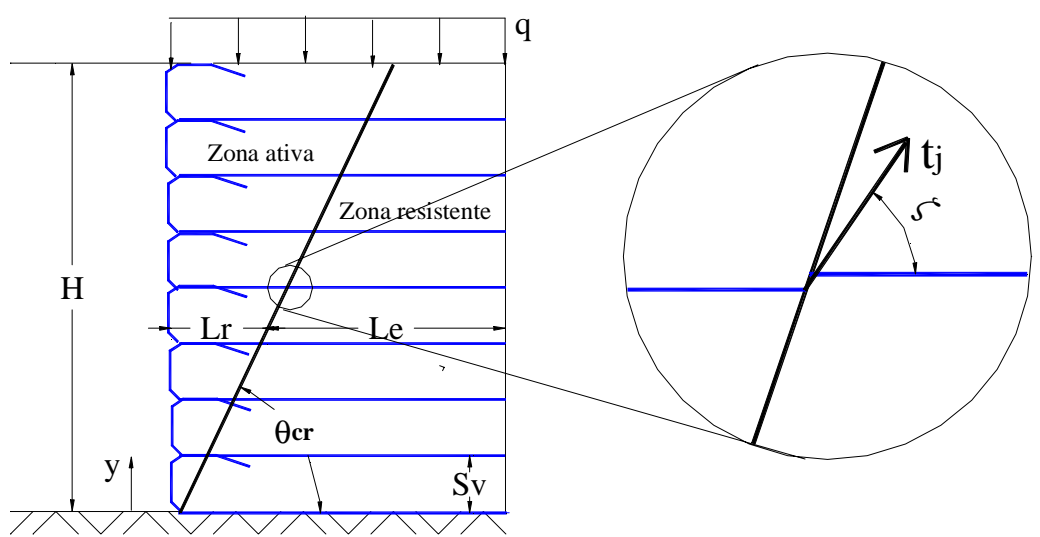

FIGURA 2.8 - Reorientação da força de tração no reforço.

A Figura 2.9 apresenta as forças atuantes no maciço, na iminência da ruptura, e o polígono de forças. A resultante das forças mobilizadas nos reforços, pela cunha de ruptura, é representada por $\left(\sum t_{j}\right)$, em que $j$ varia de 1 até a $\mathrm{n}$, representando as $\mathrm{n}$ camadas de reforço. Esta força nos reforços é inclinada de um ângulo $(\zeta)$ com a horizontal.

O valor da resultante das forças de tração nos reforços $\left(\sum t_{j}\right)$ pode ser obtida pelo equilíbrio estático feito na direção perpendicular à força de reação $\left(R_{f}\right)$, na superfície de ruptura (Figura 2.9). O valor da resultante é fornecido pela eq. (2.17).

$$
\sum_{j=1}^{n} t_{j}=\left(\frac{\gamma \cdot H}{2}+q\right) H \cdot \cot \theta \frac{\sin (\theta-\phi)}{\cos (\theta-\zeta-\phi)}
$$
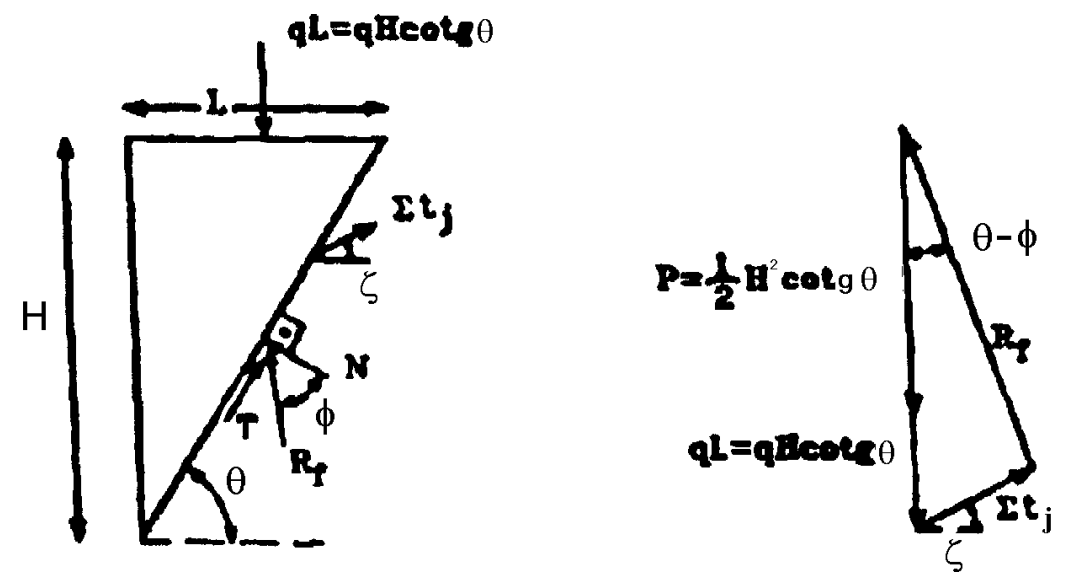

FIGURA 2.9 - Forças atuantes na cunha de ruptura e o polígono de forças (LESHCHINSKY \& PERRY, 1989). 
Examinando a eq. (2.17) observa-se que $\zeta$ contribui para a obtenção da resultante das forças nos reforços. Desta forma, nota-se que a contribuição é máxima para a estabilidade do maciço, quando $\cos (\theta-\zeta-\phi)=1$ e isto ocorre para $\zeta=\theta-\phi$. A contribuição é mínima quando $\zeta=0$. Isto define duas condições extremas e quando estes valores de $\zeta$ são substituídos na eq. (2.17) obtém-se as equações (2.18) e (2.19).

Caso 1: $\zeta=\theta-\phi$

$$
\sum_{j=1}^{n} t_{j}=\left(\frac{\gamma \cdot H}{2}+q\right) H \cdot \cot \theta_{c r} \cdot \sin \left(\theta_{c r}-\phi\right)
$$

Caso 2: $\zeta=0$

$$
\sum_{j=1}^{n} t_{j}=\left(\frac{\gamma \cdot H}{2}+q\right) H \frac{1-\sin \phi}{1+\sin \phi}
$$

O ângulo $\theta_{c r}$ é definido de tal forma que a resultante $\sum t_{j}$ seja máxima. Deste modo, $\theta_{c r}$ é definido pela figura 2.10 .

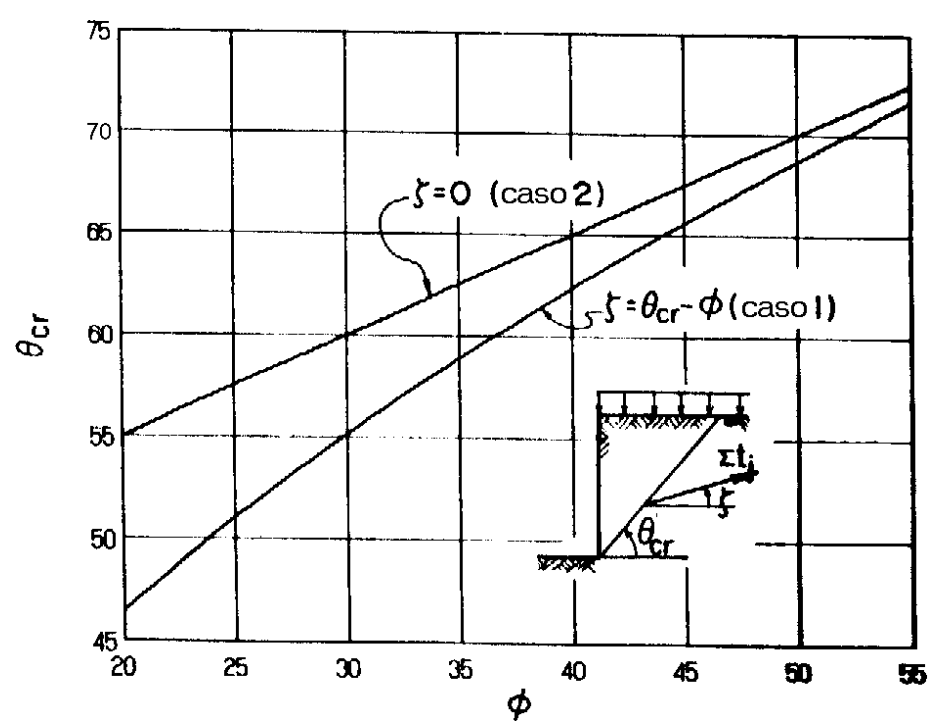

Figura 2.10 - Inclinação da superfície de ruptura, $\theta_{c r}$, como uma função de: a) inclinação da força de reforço $(\zeta)$; b) ângulo de atrito do solo $(\phi)$

(LESHCHINSKY \& PERRY, 1989). 
Para verificar a ruptura e o arrancamento do reforço é necessário conhecer a força solicitante $\left(t_{j}\right)$ em cada reforço e ela é definida pelas equações (2.20) e (2.21).

$$
\begin{aligned}
& t_{j}= t_{1} \cdot \frac{\gamma \cdot\left(H-y_{j}\right)+q}{\gamma \cdot\left(H-y_{1}\right)+q} \\
& t_{1}=\frac{\left[\gamma\left(H-y_{1}\right)+q\right] \sum t_{j}}{\sum_{j=1}^{n}\left[\gamma \cdot\left(H-y_{j}\right)+q\right]}
\end{aligned}
$$

onde: $y_{j}$ - altura da base do muro até o nível do reforço considerado;

$y_{1}$ - altura do primeiro reforço (normalmente $y_{1}=0$ );

$t_{j}$ - força de tração solicitante em cada reforço;

$t_{1}$ - força de tração que solicita o primeiro reforço ( dado pela eq. 2.21);

$\sum t_{j}$ - resultante das forças de tração (obtido da Figura 2.12);

$q$ - sobrecarga;

A verificação da ruptura do reforço é feita de maneira semelhante ao item 2.2.3.1. A principal diferença é a forma de determinação da força solicitante no reforço $\left(t_{j}\right)$ que é determinada pela eq. (2.20).

A verificação do arrancamento do reforço consiste na determinação dos comprimentos dentro da zona ativa $\left(L_{r}\right)$ e o comprimento de ancoragem $\left(L_{e}\right)$. A Figura 2.11 define o comprimento de reforço dentro da zona ativa e pode ser observado que a diferença entre os dois valores de $\zeta$ é significativa quando se utiliza ângulos de atrito menores. O comprimento do reforço determinado com $\phi=0$ e $\zeta=\theta_{\text {crit }}-\phi$ é $35 \%$ maior do que aquele correspondente a $\zeta=0$.

Para a obtenção do comprimento de ancoragem, em cada nível de reforço, utiliza-se a eq. (2.22). Entretanto, o comprimento mínimo deve ser de 0,9m.

$$
L_{e}=\frac{t_{1}}{2 \cdot \mu \cdot\left[\gamma \cdot\left(H-y_{1}\right)+q\right]}
$$

onde: $\mu$ - é o coeficiente de atrito entre o solo e o geossintético; 


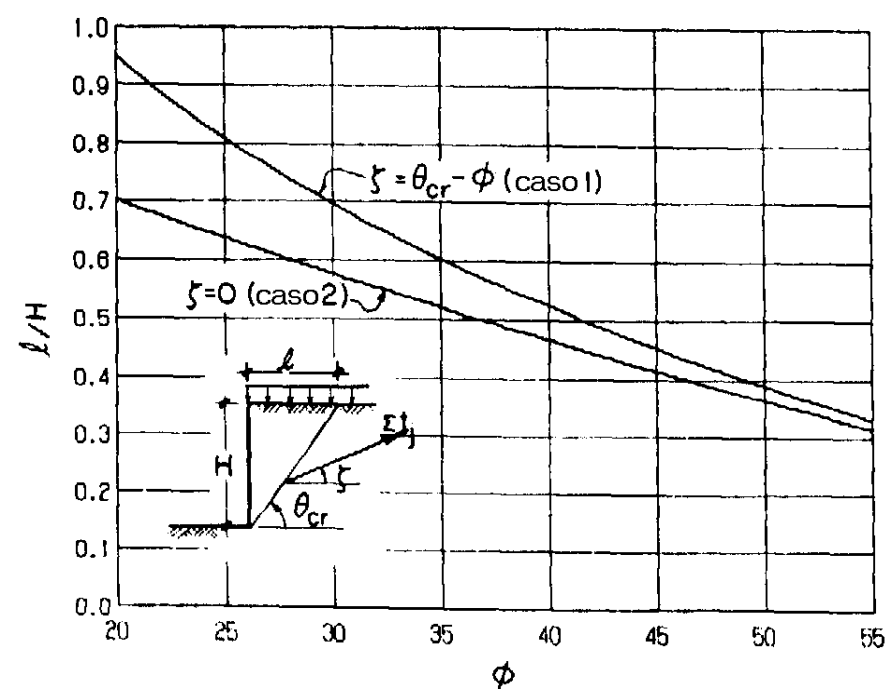

FIGURA 2.11 - Determinação da extensão da superfície de ruptura.

(LESHCHINSKY \& PERRY, 1989).

A Figura 2.12 mostra o ábaco utilizado para a obtenção do valor da resultante das forças de tração $\sum t_{j}$ adimensionalizado por $\left[\left(\frac{\gamma \cdot H}{2}+q\right) H\right]$. Estes valores são calculados pelas equações (2.18) e (2.19).

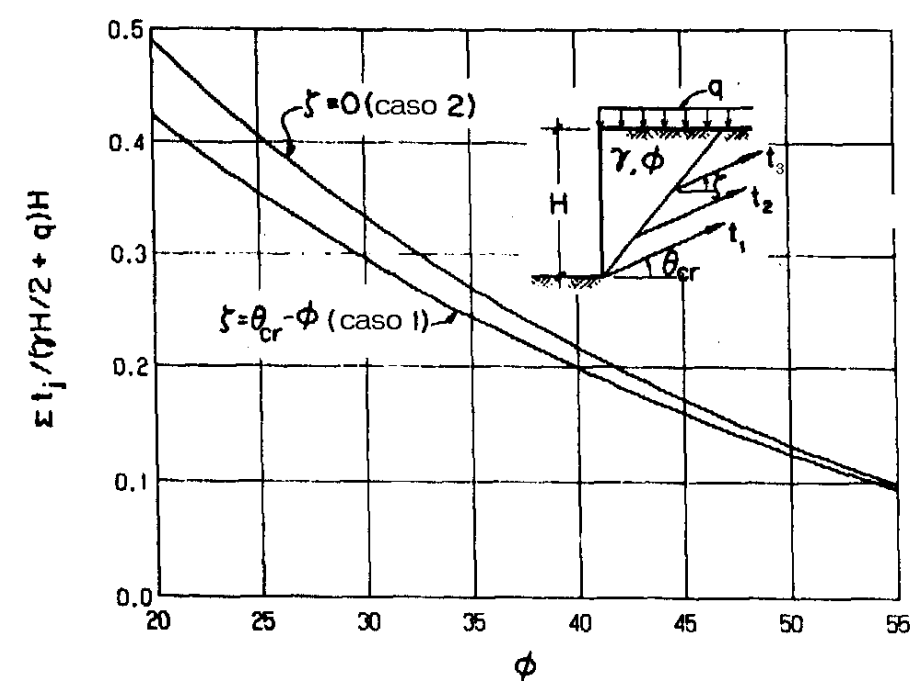

FIGURA 2.12 - Resultante das forças de tração requeridas nos reforços. (LESHCHINSKY \& PERRY, 1989).

Observa-se que o módulo de $\sum t_{j}$ é pouco afetado pela reorientação do reforço, atingindo uma diferença máxima de $15 \%$, para $\phi=20^{\circ}$, entre as duas inclinações estudadas. 
As análises convencionais, em que se considera a posição horizontal do reforço $(\zeta=0)$, podem superestimar os valores da força de tração a ser resistida pelo reforço e subestimar o comprimento de reforço necessário. Através da aplicação deste método pode-se melhorar a estimativa dos valores das forças de tração e dos comprimentos dos reforços.

\subsubsection{Método de Leshchinsky \& Boedeker}

O método desenvolvido por LESHCHINSKY \& BOEDEKER (1989) analisa a estabilidade das estruturas de contenção reforçadas com geossintéticos, tendo as superfícies potenciais de ruptura a forma de espirais logarítmicas. A Figura 2.13 mostra que a força de tração no reforço $\left(t_{m j}\right)$ pode ter uma inclinação $\theta_{j} \operatorname{com}$ a horizontal. Quando $\theta_{j}=0$, o reforço proporciona uma contribuição mínima para a estabilidade e esta condição é considerada conservadora. Quando $\theta_{j}=\beta_{j}$, a força de tração $t_{m j}$ está ortogonal ao raio da superfície de ruptura, nesta condição, o reforço produz a maior contribuição para a estabilidade.

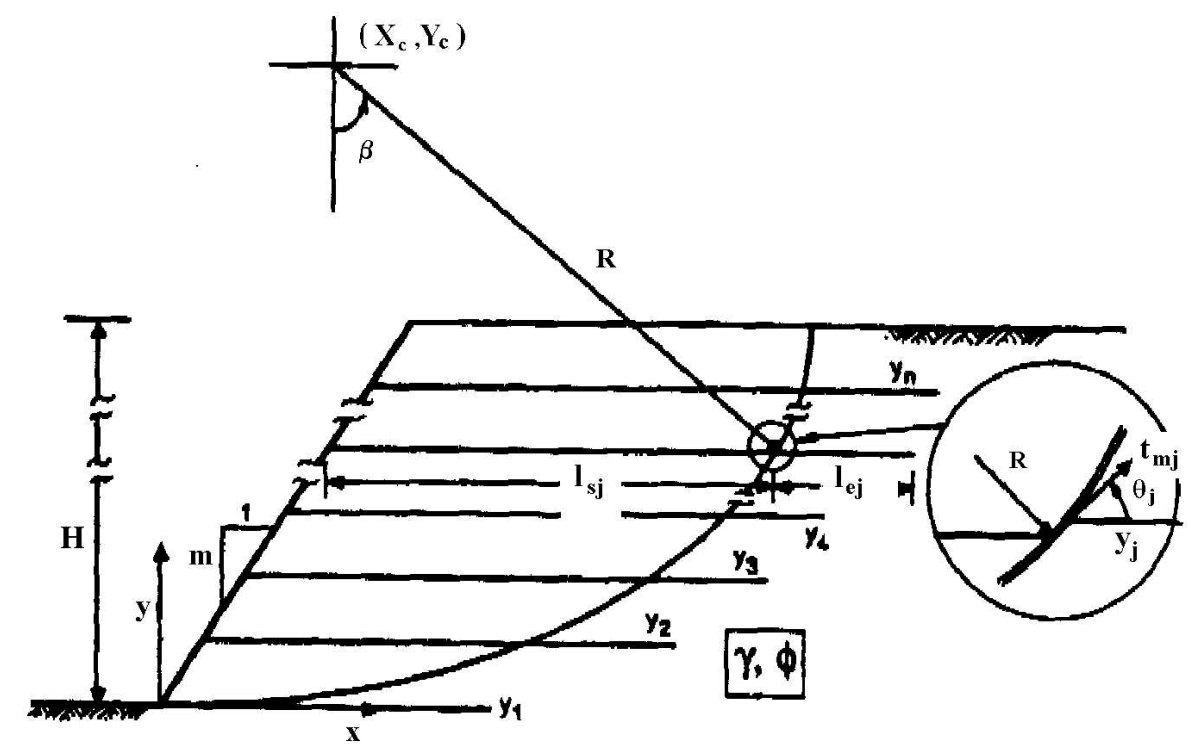

FIGURA 2.13 - Espirais logarítmicas utilizadas no método de LESHCHINSKY \& BOEDEKER (1989). 
Este método utiliza técnicas de minimização analítica para a determinação da superfície crítica, ao invés do processo iterativo de determinação da superfície crítica que é utilizado por outros métodos.

A técnica de minimização analítica consiste em desenvolver equações que fornecem diretamente a geometria da superfície crítica e o correspondente valor máximo do empuxo. Para determinar a geometria da superfície e o empuxo máximo é preciso conhecer a geometria do maciço, a resistência ao cisalhamento do solo, o número de camadas de reforço e a correspondente força de tração em cada nível de reforço.

LESHCHINSKY \& BOEDEKER (1989) calcularam os valores das forças de tração em cada nível de reforço $\left(t_{m j}\right)$ para vários aterros reforçados com diversos valores de $(\phi)$ e de inclinação do talude $(m)$. Os valores das forças de tração foram obtidos através de instrumentações de protótipos em escala real e de dados de simulações numéricas. Desta forma, os autores desenvolveram o ábaco da Figura 2.14 para calcular a força de tração $\left(T_{m}\right)$. A força de tração em cada reforço varia linearmente com a profundidade e pode ser calculada pelas equações (2.23) e (2.24).

$$
\begin{aligned}
& t_{m j}=t_{m 1}\left(1-\frac{y_{j}}{H}\right) \\
& T_{m}=\frac{1}{\gamma \cdot H^{2}} \cdot t_{m 1}
\end{aligned}
$$

onde:

$t_{m j}$ - força de tração na j-ésima camada;

$t_{m 1}$ - força de tração no primeiro reforço (calculada pela eq. 2.24);

$y_{j}$ - altura da base até a posição do primeiro reforço (normalmente $y_{1}=0$ );

$H$ - altura do maciço reforçado;

$\gamma$ - peso específico do solo;

$T_{m}$ - força de tração no primeiro reforço (obtido pela Fig.2.14); 


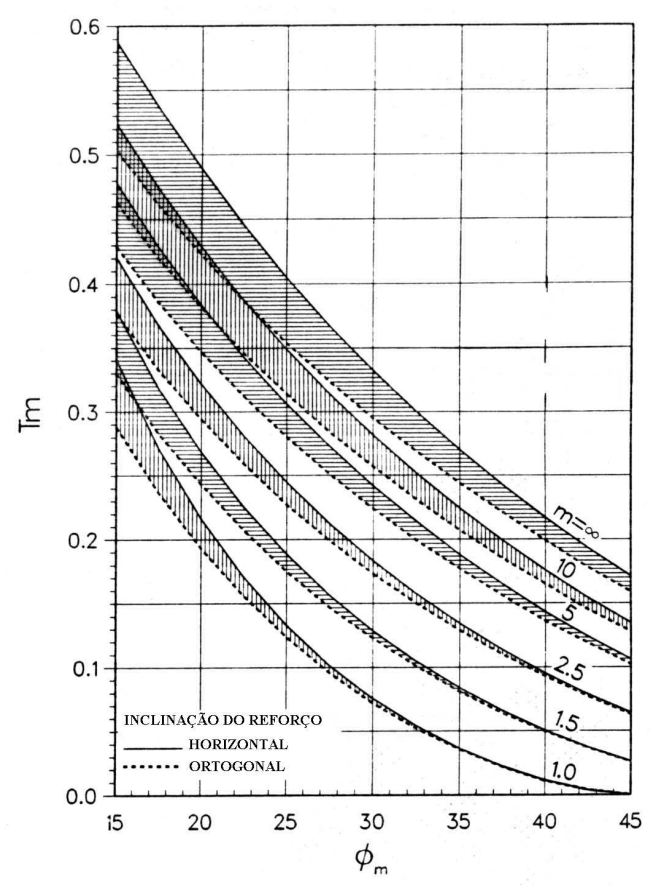

FIGURA 2.14 - Ábaco para a determinação da força de tração no reforço (LESHINSCKY \& BOEDEKER, 1989).

A verificação da ruptura do reforço é realizada de forma semelhante ao item 2.2.3.1. A principal diferença é a forma de obtenção da força de tração no reforço que é dada pelas equações (2.23) e (2.24), mostradas anteriormente.

A definição do comprimento parcial de reforço $\left(l_{s j}\right)$, dentro da zona ativa, é feita com base nos ábacos da Figura 2.15, enquanto que o comprimento de ancoragem $\left(l_{e j}\right)$ pode ser calculado pelas equações (2.25) e (2.26).

$$
\begin{aligned}
l_{e j} & =\frac{t_{m j}}{2 \cdot k \cdot \sigma_{v} \cdot \tan \phi_{m}} \\
\phi_{m} & =\tan ^{-1}\left(\frac{\tan \phi}{F S}\right)
\end{aligned}
$$

onde: $k$ - coeficiente de interação solo-reforço;

$\sigma_{v}$ - é a tensão vertical atuante no reforço;

$\phi_{m}$ - é o ângulo de atrito mobilizado;

$F S$ - fator de segurança que pode variar no intervalo de 1,3 a 1,5. 

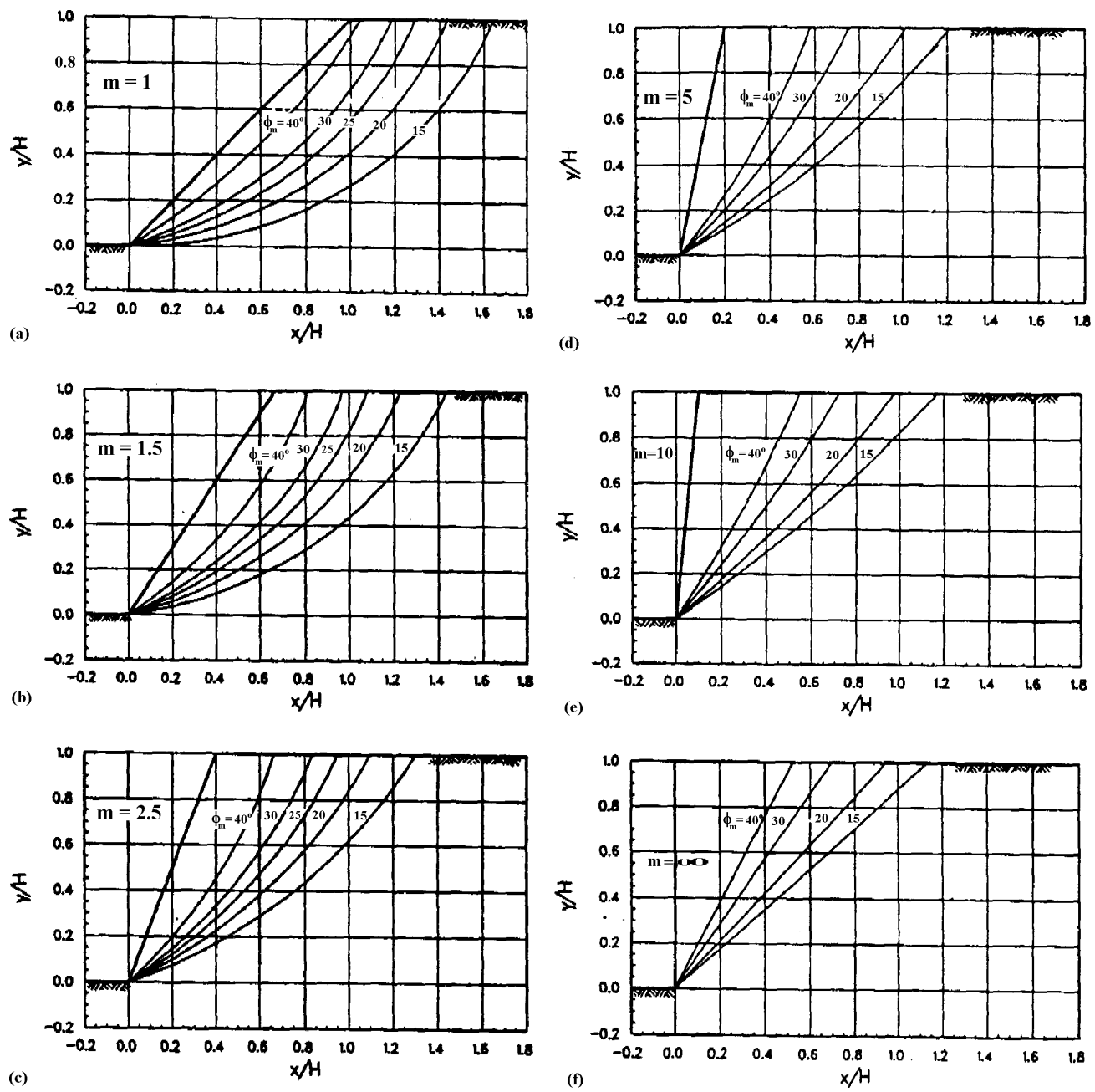

FIGURA 2.15 - Ábacos para definição da superfície de ruptura e o comprimento parcial de reforço $\left(l_{s j}\right)$ na zona ativa (LESHCHINSKY \& BOEDEKER, 1989).

O comprimento total do reforço $\left(l_{j}\right)$, de forma a assegurar a estabilidade interna do maciço, corresponde à soma de $l_{s j}$ e $l_{e j}$.

A análise da estabilidade externa é verificada pelos mecanismos clássicos mostrados no item 2.2.2 e, além disso, é feita uma verificação do deslizamento de um bloco de solo sobre cada um dos níveis de reforço, utilizando um modelo de ruptura em cunha bilinear (Figura 2.16). Conhecendo-se o coeficiente de interação soloreforço $(k)$, a inclinação do talude $(m)$ e o ângulo de atrito mobilizado $\left(\phi_{m}\right)$ determina-se o comprimento total de reforço $\left(l_{j}\right)$ pelos ábacos da Figura 2.17.

O comprimento final do reforço corresponde ao maior dos dois valores encontrados nas análises da estabilidade interna e externa. 


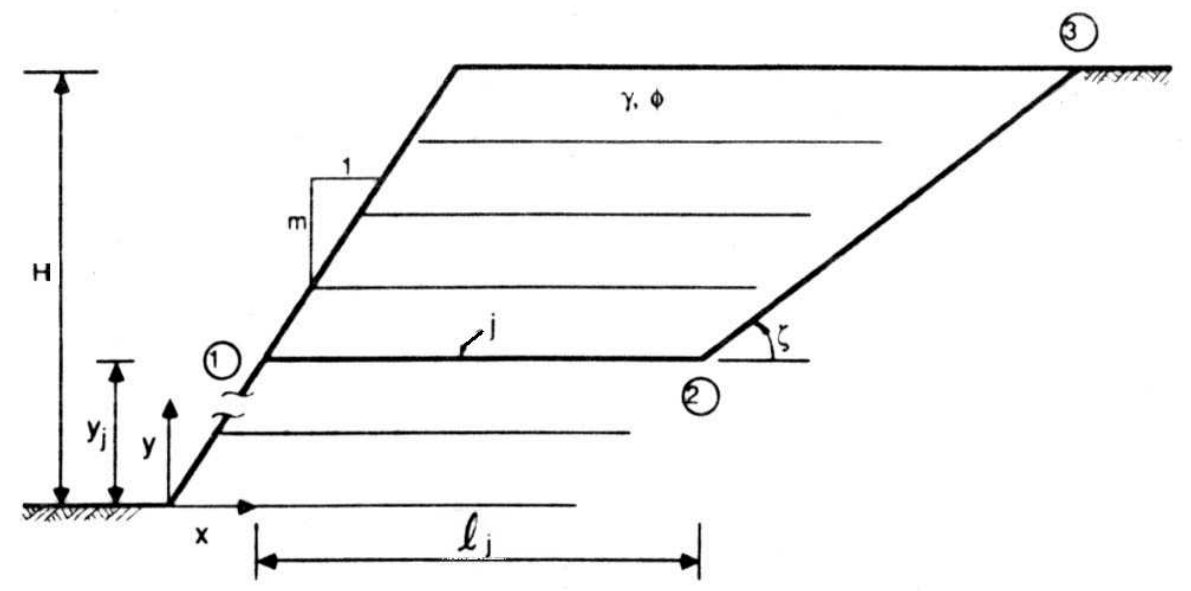

FIGURA 2.16 - Verificação da estabilidade externa (LESHCHINSKY \& BOEDEKER, 1989).
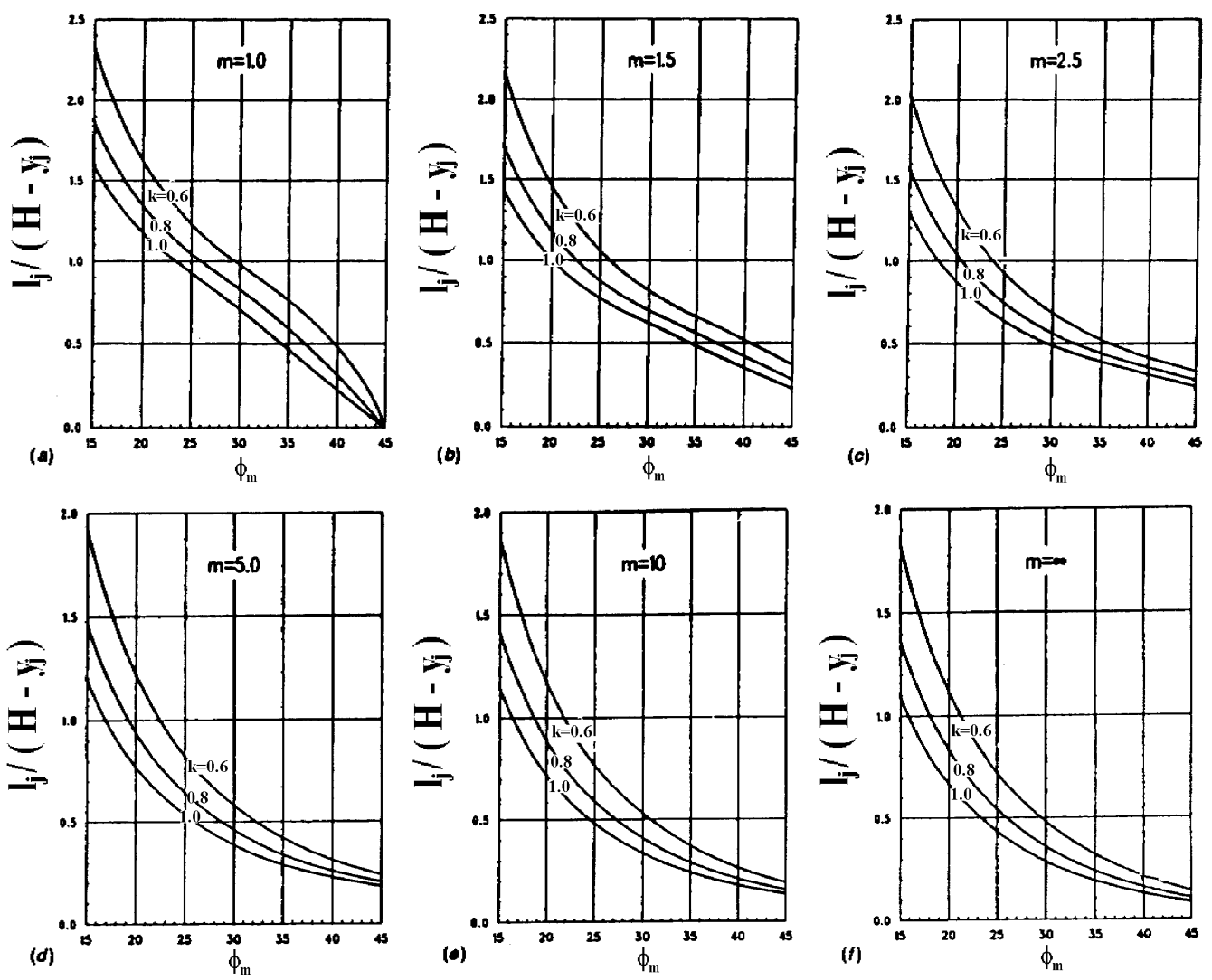

FIGURA 2.17 - Ábacos para a determinação do comprimento total de reforço, $l_{j}$, verificando a estabilidade externa (LESHCHINSKY \& BOEDEKER, 1989). 


\subsection{Fatores que influenciam no comportamento de estruturas de contenção reforçadas com geossintéticos}

O comportamento de estruturas de contenção em solo reforçado é influenciado por vários fatores; os principais são a rigidez da face, o tipo de solo, o tipo de inclusão, o grau de compactação, o arranjo das inclusões. É de suma importância conhecer melhor estes fatores para se ter uma melhor previsão do mecanismo de ruptura, da quantificação dos deslocamentos horizontais e dos esforços nas inclusões. Assim sendo, será apresentado o tipo de influência que cada fator exerce no desempenho das estruturas reforçadas com geossintéticos.

\subsubsection{Rigidez da face}

A face de uma estrutura de contenção em solo reforçado é construída com a finalidade de aumentar a durabilidade, melhorar a estética e facilitar a construção da estrutura. Além disso, a face contribui para melhorar o desempenho estrutural do sistema. TATSUOKA (1992), por exemplo, mostrou através de modelos reduzidos e modelos em escala real que a face aumenta o confinamento do solo adjacente e absorve esforços em sua superfície. Por isto, a face exerce grande influência na estabilidade das estruturas em solo reforçado. No entanto, a contribuição da rigidez da face não é considerada pelos métodos convencionais de dimensionamento de estruturas de contenção reforçadas com geossintéticos.

TATSUOKA (1992) classificou a rigidez da face em local e global. A rigidez local é definida como a característica que a face possui em conseguir ativar empuxos de terra sobre a sua superfície. A rigidez global é subdividida em axial, cisalhante e à flexão, cada uma delas contribui para que a face resista a esforços axiais, cisalhantes e momentos fletores, respectivamente.

Existem vários tipos de face e cada uma possui uma rigidez distinta, dentre os principais tipos podem ser citadas: as em lâminas metálicas, as formadas com sacos de areia, as de painéis de concreto como os da terra armada, as de blocos de concreto, em laje contínua, dentre outras. 


\subsubsection{Influência do empuxo ativado sobre a superfície da face}

Os empuxos atuantes nas estruturas envelopadas com geotêxtil não são, adequadamente, suportados pelas mesmas. Isto se deve ao insuficiente confinamento do solo e à consequente pequena resistência ao cisalhamento do solo, nas partes mais próximas da face, provocados pela ausência de uma face (TATSUOKA, 1992). Este autor mostrou que pode haver uma ruptura por compressão local, do solo, imediatamente atrás da face, induzindo uma ruptura progressiva em direção ao interior do maciço e causando o aparecimento de fissuras com posterior ruptura global do muro (Figura 2.18).

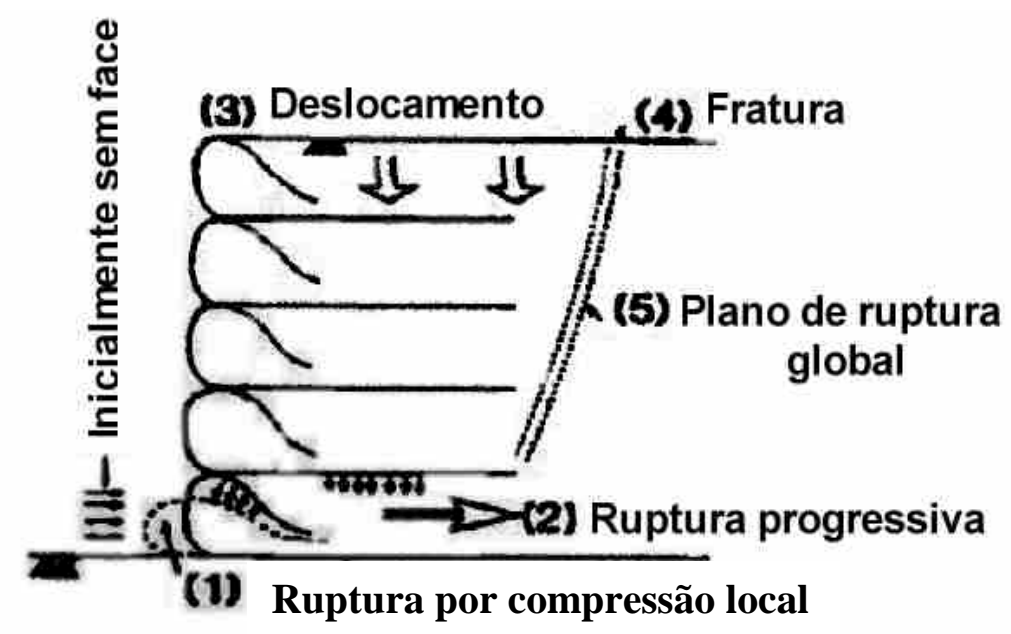

FIGURA 2.18 - Ruptura progressiva iniciando a partir de uma ruptura compressional local do solo na estrutura em solo reforçado (TATSUOKA, 1992).

A introdução de uma face aumenta o confinamento do solo e parte das tensões horizontais, geradas no maciço reforçado, são transferidas para ela. Isto diminui a possibilidade de uma ruptura localizada. A Figura 2.19 mostra, esquematicamente, a distribuição da força de tração em estruturas em solos reforçados, com e sem engastamento à face, respectivamente. 


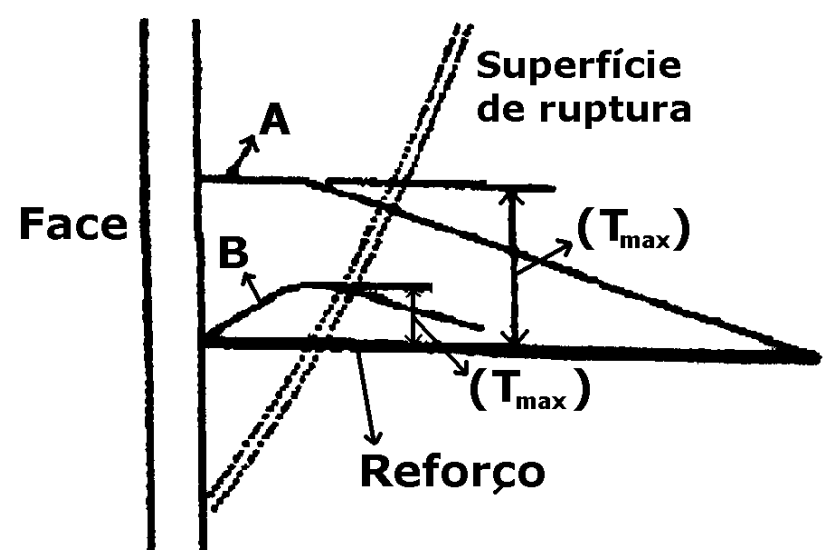

FIGURA. 2.19 - Os modelos A e B representam a distribuição da força de tração no reforço para uma estrutura em solo reforçado. (TATSUOKA, 1992).

O modelo B mostra a situação de ausência da face ou quando o reforço não é conectado à mesma. $\mathrm{O}$ modelo $\mathrm{A}$ representa um reforço conectado à face. A força de tração é constante e igual a ( $\left.\mathrm{T}_{\text {máx }}\right)$ nas proximidades da face e decresce ao longo do comprimento do reforço até se anular. No modelo $\mathrm{B}$, a força de tração é nula próxima à face e cresce ao valor ( $\left.\mathrm{T}_{\text {máx }}\right)$ no plano potencial de ruptura e volta a decrescer até anular-se na extremidade do reforço.

\subsubsection{Resultados de ensaios em protótipos e modelos reduzidos}

Os efeitos da rigidez da face foram observados com a construção de dois muros de arrimo em solos reforçados com geotêxteis com 5,0m de altura (TATSUOKA et al., 1989). O primeiro muro possuía menor rigidez que o segundo. Foram observadas maiores deformações na face do primeiro muro do que na do segundo. Além disso, foi observado que as forças de tração, próximas à face do segundo muro, eram maiores que as do primeiro muro. Isto mostra que existe uma transferência de tensões para a face, reduzindo os deslocamentos horizontais do maciço reforçado.

BOLTON \& PANG (1982) observaram através de ensaios realizados em centrífuga uma redução das tensões verticais, nas fundações do maciço reforçado, quando foram utilizadas faces rígidas. $\mathrm{O}$ atrito entre a face e o solo permitiu o desenvolvimento de tensões cisalhantes na superfície da face. Com isto, houve uma redução das tensões verticais nas fundações do maciço reforçado. Estes autores também concluíram que esta redução dependia do coeficiente de atrito entre a face e 
o solo. Quanto maior o coeficiente de atrito maior a redução de tensões verticais nas fundações.

JABER (1989) realizou ensaios em centrífugas, com modelos de muros de arrimo de 1,5 m de altura. Ele mostrou que faces de painéis rígidos contínuos são mais rígidas do que faces de blocos de concreto. Entretanto, faces de painéis rígidos contínuos tem como desvantagem um processo executivo mais difícil do que as faces de blocos de concreto. Por isto, as faces de blocos de concreto são atualmente, mais utilizadas do que faces rígidas contínuas.

KAWASAKI* apud TATSUOKA (1992) realizou ensaios em muros de solos reforçados com $5 \mathrm{~m}$ de altura construídos com diferentes tipos de face. O primeiro muro possuía uma face envelopada com geotêxtil. O segundo tinha uma face de painéis rígidos contínuos e o geotêxtil foi conectado à esta face. $\mathrm{O}$ terceiro muro foi um muro convencional de concreto (tipo gravidade) e o aterro não foi reforçado com geotêxtil. Com a aplicação de uma sobrecarga o primeiro muro exibiu um sinal de ruptura compressional local, conforme foi mostrado no item 2.3.1.1. A superfície de ruptura interceptou a face do muro no topo da segunda camada de reforço. No segundo muro não ocorreu ruptura provavelmente devido à presença da face rígida. O terceiro muro se comportou como o segundo. Estes resultados indicam claramente que para a estabilidade de um muro de arrimo em solo reforçado ser equivalente a de um muro convencional, apenas as forças mobilizadas no reforço não são suficientes é preciso que a face ajude na estabilidade através da sua rigidez.

BATHURST et al. (1988) construíram dois muros de arrimo de $3 \mathrm{~m}$ de altura que foram reforçados com geogrelhas. O primeiro possuía uma face em laje contínua e o segundo uma face de painéis de concreto. As faces foram escoradas durante o período de execução dos muros e, em seguida, os muros foram levados à ruptura por uma sobrecarga aplicada no topo do aterro reforçado. A face em laje contínua funcionou melhor que a face de painéis de concreto, apresentando menores deslocamentos horizontais e maior transmissão de tensões horizontais para a face. Observou-se também que antes e após a aplicação das sobrecargas, nas proximidades da base do muro, grande parte das tensões verticais foram transferidas para a face. Esta transferência foi em torno de $25 \%$ para ambas as faces.

* KAWASAKY, H.;HIRAI, T.; FURUKAWA, O.; SATO, M.; SEKIJIMA, K.; KAWABE, M. (1990). Large-scaled test on the reinforced embakment with geotextiles. In: $25^{\text {th }}$ Japan National Conference on SMFE, p. 1981-1984 apud TATSUOKA (1992). Roles of facing rigidity in soil reinforcing. In: International Symposium on Earth Reinforcement Practice, v.2, p. 831-870. 
Os dados apresentados indicam que as faces que possuem maior rigidez fornecem um comportamento mais estável do que as menos rígidas. Além disso, pode-se dizer que as estruturas em solo reforçado, que possuem reforços conectados à uma face rígida, comportam-se numa posição intermediária entre as estruturas em solo envelopado e as estruturas de contenção convencionais de concreto.

\subsubsection{Tipo de solo}

Na natureza existem vários tipos de solos, no entanto, apenas uma porcentagem limitada de solos é satisfatória para ser usada em estruturas de contenção reforçadas com geossintéticos.

JONES (1990) mostrou que um solo ideal para ser usado no aterro de uma estrutura de contenção reforçada, deve ser um material granular, bem graduado e com boa drenagem. O solo precisa oferecer durabilidade a longo prazo, estabilidade durante a construção e possuir boas propriedades físico-químicas. Os solos granulares bem graduados satisfazem a estes requisitos. Eles apresentam comportamento (tensão x deformação) elástico e os movimentos pós-construção, devido a deformações plásticas, normalmente não ocorrem nestes materiais. Os solos finos, por sua vez, não apresentam boa drenagem e, normalmente, apresentam comportamento elasto-plástico ou plástico. Com este tipo de solo aumentam-se as chances de movimentos pós-construção.

As especificações de materiais para aterro de estruturas de contenção em solos reforçados são recomendadas pela FHWA (Federal Highway Administration) conforme CHRISTOPHER et al. (1990). Estas especificações e alguns solos encontrados na literatura estão apresentados na Figura 2.20. Além das especificações granulométricas, a FHWA recomenda que o índice de plasticidade máximo deve ser de 6, o material deve ser pouco plástico. O diâmetro máximo do grão está limitado a $19 \mathrm{~mm}$ para reforços extensíveis, a menos que ensaios de campo sejam realizados para avaliar a redução da resistência devido aos danos de instalação do reforço.

Apesar destas especificações, o aspecto econômico da escolha do tipo de solo é muito importante. Por exemplo, a escolha de solos locais proporcionam maior economia, no entanto, estes solos podem não atender às especificações da FHWA, como mostra a Figura 2.20. Os solos que não atendem a estas especificações podem 
apresentar propriedades insatisfatórias que foram destacadas por JEWELL \& JONES (1981) e MITCHELL (1981) como: a) os solos coesivos são pouco drenáveis e podem desenvolver pressão neutra, que reduz a resistência do solo do reaterro. Além disto, a resistência drenada de solos coesivos é menor que a dos solos não coesivos; b) solos coesivos são quimicamente mais agressivos que solos não coesivos; c) movimentos pós-construção podem ocorrer por causa do grande potencial de fluência que solos coesivos possuem.

Apesar de solos coesivos apresentarem propriedades insatisfatórias, vários autores construíram estruturas de contenção em solos reforçados, com segurança e economia, utilizando este tipo de solo. Dentre os autores destacam-se EHRLICH et al.(1994) e RIBEIRO et al. (1999) que comprovaram a boa eficiência de solos coesivos através de suas instrumentações de campo.

Os solos apresentados na Figura 2.20 foram encontrados na literatura e suas características granulométricas estão mostradas na Tabela 2.2.

TABELA 2.2 - Características granulométricas de alguns solos.

\begin{tabular}{|c|c|c|c|c|c|}
\hline $\begin{array}{c}\text { Localização do } \\
\text { solo }\end{array}$ & \multicolumn{2}{|c|}{ Granulometria (\%) } & \multicolumn{2}{|c|}{ Classificação } & \multirow{2}{*}{ Referências } \\
\cline { 2 - 5 } & Areia & Silte & Argila & Silte argiloso, pouco arenoso & GIAGHETI \\
São Carlos & 64 & 10 & 26 & Areia média a fina, pouco argilosa & VILAR (1979) \\
\hline Ribeirão Preto & 8 & 52 & 40 & Silte arenoso, pouco argiloso & (1979) \\
\hline Jaú & 37 & 38 & 25 & \\
\hline
\end{tabular}

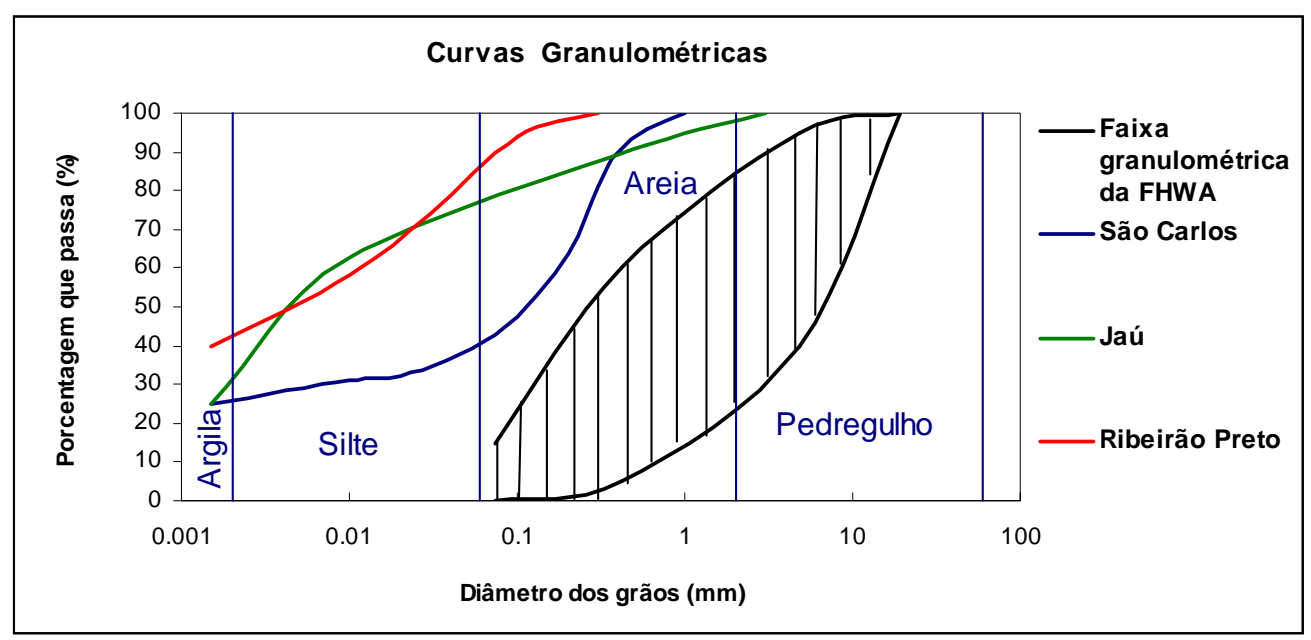

FIGURA 2.20 - Curvas granulométricas de alguns solos e a faixa granulométrica recomendada pela FHWA para a construção de estruturas em solo reforçado. 
Um estudo de laboratório foi realizado por ELIAS* apud ZORNBERG (1994), para analisar a possibilidade de usar materiais com granulação fina em estruturas de terra armada. Este estudo concentrou-se na determinação de coeficientes de atrito solo-reforço, através de ensaios de arrancamento, que foram realizados usando amostras compactadas próximas ao teor de umidade ótimo. Os solos utilizados nos ensaios possuíam diferentes granulometrias e teores de umidade. $\mathrm{O}$ autor comprovou que há uma grande redução do coeficiente de atrito com o aumento de finos do solo. Observou-se também que o coeficiente de atrito solo-reforço apresenta uma significativa diminuição quando o teor de umidade está acima do ótimo.

O confinamento do solo influencia, significativamente, a resistência do reforço. Esta influência é devida às tensões de compressão que o solo exerce e pela interpenetração entre o mesmo e o reforço. CAZUFFI et al. (1994) realizaram ensaios em geotêxteis não tecidos para verificar o comportamento tensão $\mathrm{x}$ deformação dos geotêxteis, quando estão submetidos a tensões geostáticas impostas pelo confinamento do solo. Eles observaram que o confinamento do solo aumenta a rigidez e a tensão de ruptura dos geotêxteis. Isto prova que os projetos possuem fatores de segurança maiores que o necessário, pois eles não consideram o efeito benéfico do confinamento dos solos.

\subsubsection{Tipos de influência do solo no desempenho das estruturas}

O tipo de solo pode influenciar nos deslocamentos horizontais e na mobilização das forças de tração dos reforços das estruturas de contenção executadas com geossintéticos.

HELMANY et al.(1999) realizaram simulações numéricas com 16 tipos de solo e 3 tipos de inclusões. Os solos e inclusões possuíam módulos de rigidez distintos. Eles observaram que para solos mais rígidos os deslocamentos horizontais são bem menores do que para solos menos rígidos. $\mathrm{O}$ aumento da rigidez das inclusões não implica em uma redução significativa dos deslocamentos horizontais, quando o solo for rígido. Concluiu-se que o tipo de solo é o fator que mais contribui na magnitude dos deslocamentos horizontais das estruturas de contenção reforçadas com geossintéticos. A rigidez do solo também foi estudada por ADIB et al. (1990). Eles mostraram, através de resultados de instrumentação de obras e simulações

* ELIAS (1979). Friction in reinforced earth utilizing fine grained backfills. In: Coloque International sur le Renforcement des sols, Paris, v.2, p. 435-438 apud ZORNBERG (1994). Performance of geotextile reinforced soil structures. Ph.D. thesis, University of California at Berkeley, 504p. 
numéricas, que estruturas construídas com solos mais rígidos caracterizam-se por apresentarem deslocamentos menores do que aquelas construídas com solos menos rígidos.

O tipo de solo também afeta a mobilização das forças de tração máximas nos reforços. ADIB et al. (1990) mostraram que as forças de tração máximas nas inclusões são maiores para solos menos rígidos do que para solos mais rígidos. Isto pode ser visto na Figura 2.21, onde o parâmetro K é o número do módulo de rigidez do solo. O seixo rolado é mais rígido que a areia pedregulhosa que, por sua vez, é mais rígida do que o silte. Admitindo-se que o empuxo, o número de inclusões e suas propriedades mecânicas sejam iguais, nos três tipos de solos considerados, e que o conjunto solo-geossintético absorva todo o empuxo gerado; se o solo dispõe de maior resistência ao cisalhamento, o conjunto irá requerer menor contribuição dos reforços e, consequentemente, precisam mobilizar menores forças nas inclusões para garantir o equilíbrio do sistema. Por isto, as estruturas de contenção construídas com solos mais rígidos mobilizam menos forças nas inclusões do que as que são construídas com solos menos rígidos.

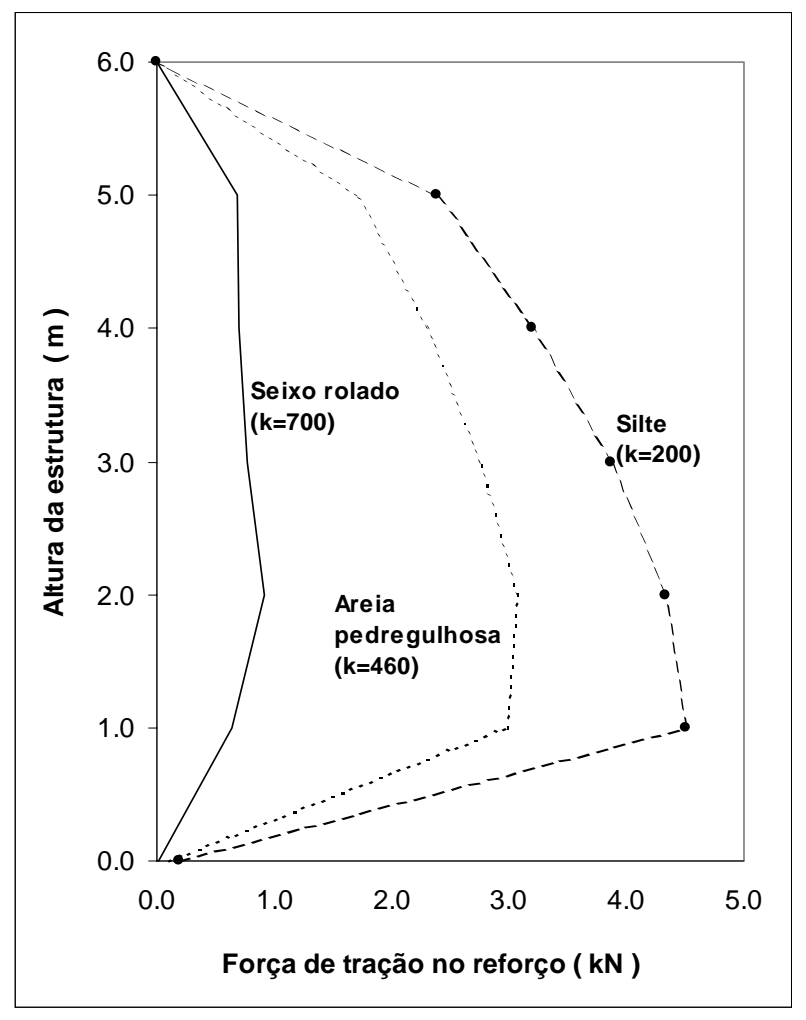

FIGURA 2.21 - Forças de tração máximas ao longo da altura da estrutura (ADIB et al., 1990). 
Observa-se que, próximo à base da estrutura, há uma considerável diminuição das forças de tração. Esta redução das forças de tração na base da estrutura de contenção é devido à influência da fundação. Este efeito foi observado por vários autores (ADIB et al.,1990; CHALATURNYK \& SCOTT, 1990; KARPURAPU \& BATHURST, 1992; ROWE \& HO, 1992; SIMAC et al.,1990; THAMM \& LESNIEWSKA, 1990 ). O atrito entre a fundação e o maciço reforçado é a possível causa desta redução nas forças de tração na base da estrutura. Esta observação é importante pois, convencionalmente se considera que a distribuição de tensões horizontais seja triangular o que requer uma grande concentração de inclusões na base da estrutura.

\subsubsection{Tipo de inclusão}

Os geossintéticos empregados como reforço de estruturas de contenção são as geogrelhas e os geotêxteis. Para que um geossintético seja satisfatório, para ser usado em estruturas de solos reforçados, ele precisa ter suficiente resistência à tração e durabilidade. Além disso, ele deve apresentar uma boa aderência com o solo de forma que a deformação do solo produza deformação no geossintético. Para que isto aconteça o geossintético deve apresentar uma suficiente rigidez à tração.

\subsubsection{Tipo de influência da inclusão no desempenho das estruturas}

O tipo de inclusão influencia na magnitude dos deslocamentos horizontais, na mobilização das forças nas inclusões e na localização da superfície de ruptura.

Aumentos da rigidez da inclusão produzem reduções dos deslocamentos horizontais de estruturas em solos reforçados (ADIB et al., 1990; LING et al. 1995; ROWE \& HO, 1998). Reforços mais rígidos precisam sofrer menores deslocamentos para que mobilizem maiores forças de tração. Esta é a razão utilizada para explicar que reforços mais rígidos permitem menores deslocamentos horizontais de estruturas em solo reforçado.

Quanto à mobilização das forças de tração, ao longo da altura da estrutura, ROWE \& HO (1992) mostraram que com o aumento da rigidez da inclusão as forças de tração mobilizadas nas inclusões aumentam. Além disso, as forças de tração 
aumentam com o acréscimo das tensões geostáticas provocadas pelo aumento da altura da estrutura (HO \& ROWE, 1998).

No que se refere à definição do mecanismo de ruptura, MITCHELL \& VILLET (1987) mostraram que um dos fatores que afeta a forma da superfície de ruptura é a rigidez da inclusão. No caso de reforços inextensíveis, ou seja, inclusões metálicas, a superfície de ruptura hipotética é bilinear. Para reforços extensíveis, ou seja, geogrelhas e geotêxteis, ela assume a forma linear. A Figura 2.22 apresenta esquematicamente a forma destes dois tipos de superfícies de ruptura.

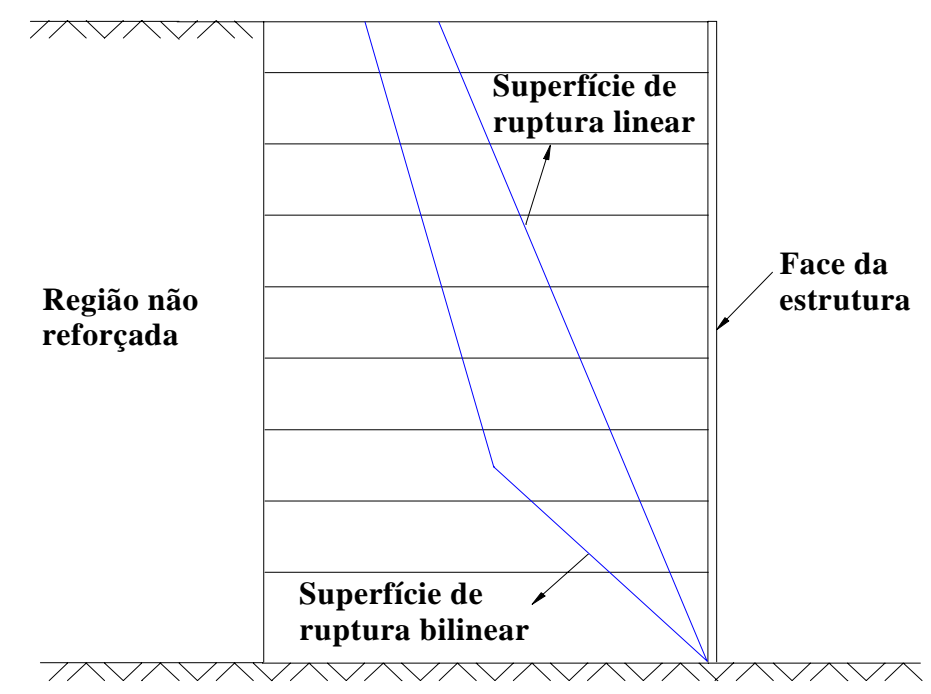

FIGURA 2.22 - Superfícies de ruptura linear e bilinear.

ADIB et al. (1990) mostraram, também, que a rigidez do reforço afeta a localização da superfície de ruptura. $\mathrm{O}$ aumento da rigidez do reforço faz com que a superfície de ruptura fique mais próxima da face. ZORNBERG et al. (1998), no entanto, realizaram ensaios em modelos reduzidos em centrífuga variando a rigidez do solo e das inclusões e observaram que a localização das superfícies de ruptura são, aproximadamente, as mesmas, independente dos valores de rigidez utilizados.

\subsubsection{Características geométricas da estrutura}

As características geométricas mais importantes da estrutura são a relação entre o comprimento da inclusão e a altura do muro $(\mathrm{L} / \mathrm{H})$ e o arranjo das inclusões. Estas 
características influenciam na localização da superfície de ruptura, nos deslocamentos horizontais e na mobilização das forças de tração nas inclusões.

\subsubsection{Influência da relação $L / H$ no desempenho das estruturas}

PORBAHA (1998) mostrou através de modelos ensaiados em centrífuga que a relação entre o comprimento do reforço e a altura do muro $(\mathrm{L} / \mathrm{H})$ influencia na posição da superfície de ruptura (Figura 2.23). À medida que esta relação cresce entre os limites de 0,50 e 0,75 , a superfície de ruptura se move em direção à face. As inclusões dão contribuição máxima para a estabilidade interna da estrutura quando a superfície de ruptura está inteiramente situada dentro da zona reforçada e simultaneamente apresentam comprimento de ancoragem suficiente ao longo de toda a altura do muro. Esta condição acontece quando a relação $(\mathrm{L} / \mathrm{H})$ é igual a 0,75.

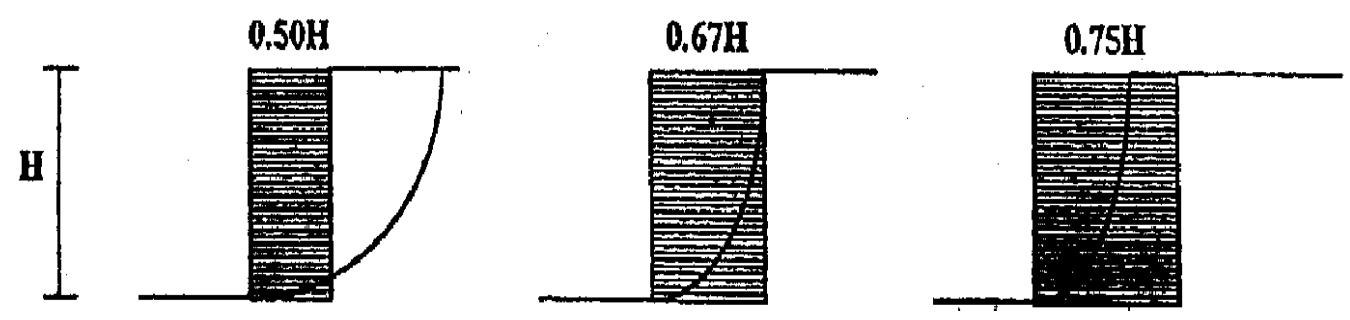

FIGURA 2.23 - Posição da superfície de ruptura de acordo com a relação L/H (PORBAHA, 1998).

Quanto aos deslocamentos horizontais, ROWE \& HO (1998) mostraram, através de simulações numéricas, que a relação L/H exerce grande influência nos deslocamentos horizontais das estruturas de contenção em solo reforçado. Eles observaram que os deslocamentos reduzem quando se aumenta a relação $(\mathrm{L} / \mathrm{H})$. $\mathrm{HO}$ \& ROWE (1996) mostraram que a relação $(\mathrm{L} / \mathrm{H}=0,7)$ pode ser considerada a ideal. Esta relação garante uma maior eficiência quanto aos deslocamentos horizontais, às forças de tração mobilizadas nas inclusões e apresenta uma boa economia de reforço.

\subsubsection{Influência dos arranjos das inclusões no desempenho das estruturas}

Os arranjos dos geossintéticos no maciço é um fator importante que merece destaque na construção de obras de solos reforçados. LANZ \& PALMEIRA (1994) 
realizaram ensaios em modelos reduzidos de muros de solos reforçados com geotêxteis, cuja altura era de $440 \mathrm{~mm}$. O objetivo dos ensaios foi avaliar a influência de vários arranjos de reforço no comportamento das estruturas reforçadas. Os arranjos estudados estão mostrados na Figura 2.24.
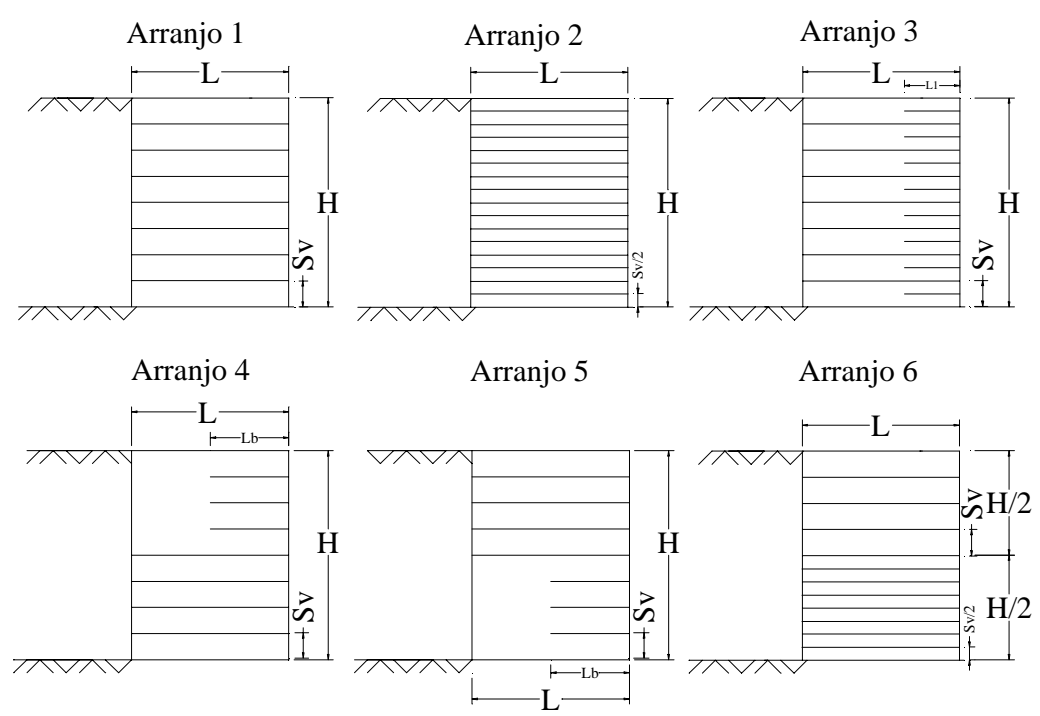

FIGURA 2.24 - Arranjos de reforços ensaiados (LANZ \& PALMEIRA, 1994).

Os arranjos mais comuns encontrados na literatura são os dos tipos 1 e 2. Estes arranjos apresentam espaçamento e comprimento de reforços constantes. LANZ \& PALMEIRA (1994) observaram que o arranjo 2, por ter uma maior densidade de reforço, apresentou menores deslocamentos horizontais na face. Entretanto, o mesmo nível de deslocamentos foi observado para o arranjo 6, apesar do maior espaçamento entre reforços na parte superior do muro. Nos muros 4 e 5 foram observados maiores deslocamentos horizontais nas regiões de menor comprimento de reforço. O muro 4 apresentou uma deficiência de comprimento de ancoragem no trecho superior da estrutura. Por isto, houve um aumento de $100 \%$ nos deslocamentos horizontais da face nesta região, em comparação com os resultados observados para o muro 2. Eles mostraram que a grandeza dos deslocamentos horizontais da face é função, também, do espaçamento entre reforços. Entretanto, o espaçamento afetou menos os deslocamentos horizontais do que o comprimento dos reforços, devido à redução do comprimento dos reforços permitir que a massa não reforçada trabalhe mais. A presença dos reforços secundários no muro 3 não afetou a grandeza dos deslocamentos observados. O arranjo que apresentou maior economia de reforço e menor deslocamento foi o arranjo 6. 


\subsubsection{Efeito da compactação}

O efeito da compactação do maciço acarreta um aumento das tensões horizontais próximas à face e, portanto, um aumento de deslocamentos horizontais da estrutura de contenção. Alguns autores propuseram métodos para quantificar o acréscimo de tensões horizontais sobre estruturas de contenção devido à compactação (BROMS, 1971; DUNCAN \& SEED, 1986; EHRLICH \& MITCHELL, 1994; INGOLD, 1979).

Para reduzir o efeito da compactação nas estruturas de contenção, alguns autores sugerem reduzir o grau de compactação do solo em uma faixa próxima à face (Figura 2.25). Isto provocaria uma diminuição do empuxo lateral e, consequentemente, dos deslocamentos da estrutura. McGOWN et al. (1988), KARPURAPU \& BATHURST (1992) e MARQUES (1994) verificaram o efeito benéfico desta faixa com menor grau de compactação próximo à face e confirmaram a redução do empuxo e, consequentemente, dos deslocamentos horizontais da estrutura.

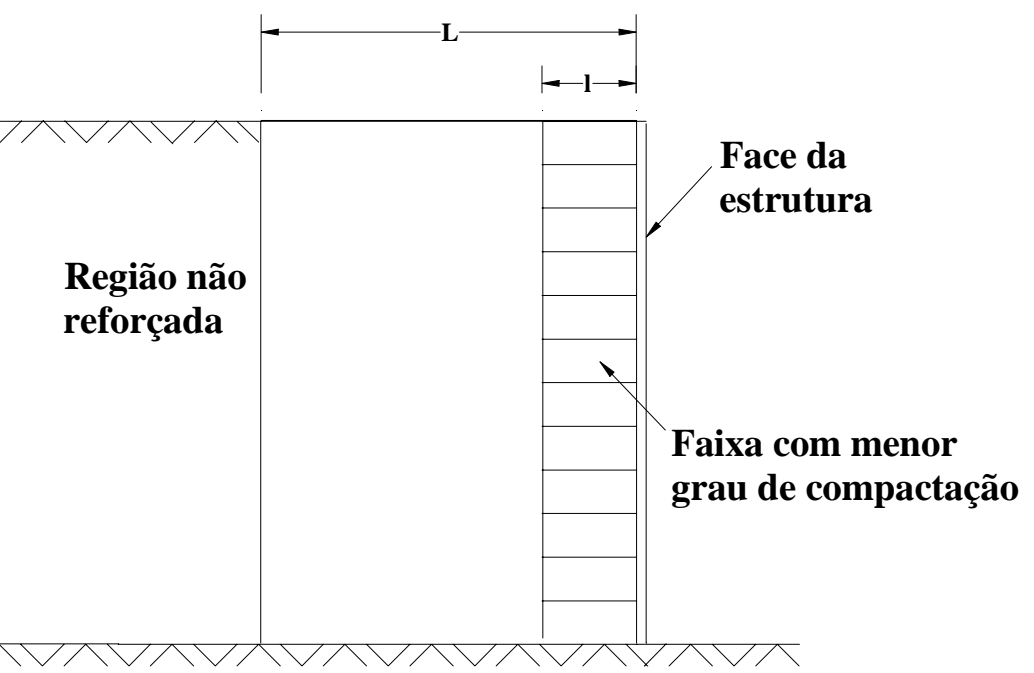

FIGURA 2.25 - Estrutura em solo reforçado com faixa com menor grau de compactação.

KARPURAPU \& BATHURST (1992) realizaram simulações numéricas e elaboraram ábacos que permitem prever as tensões e os deslocamentos da face de estruturas reforçadas para diversos tipos de solo, largura da faixa menos compactada e grau de compactação desta faixa. 


\subsection{Utilização de MEF em estruturas em solo reforçado}

Existe uma considerável quantidade de pesquisas desenvolvidas para investigar o desempenho das estruturas de contenção com solos reforçados usando o Método dos Elementos Finitos (MEF) (ADIB et al.; 1990; HELMANY et al., 1999; ROWE \& HO, 1998; KARPURAPU \& BATHURST, 1995).

Os métodos de projeto de estruturas de solos reforçados são, geralmente, baseados em teorias de equilíbrio limite que não consideram explicitamente nem as deformações do solo, nem a interação que ocorre entre os elementos de reforço e o solo. Com a utilização do MEF, estas limitação podem ser ultrapassadas, possibilitando o estudo adequado de estruturas de solo reforçados (AZEVEDO et al., 1992).

AZEVEDO et al. (1992) citam que existem duas maneiras de representar solos reforçados através do método dos elementos finitos. A primeira é chamada de representação composta que utiliza um único elemento para representar o solo reforçado. A segunda é denominada representação discreta, em que se utilizam diferentes elementos para representar o solo e o reforço, com ou sem interface entre ambos (FIGURA 2.26).

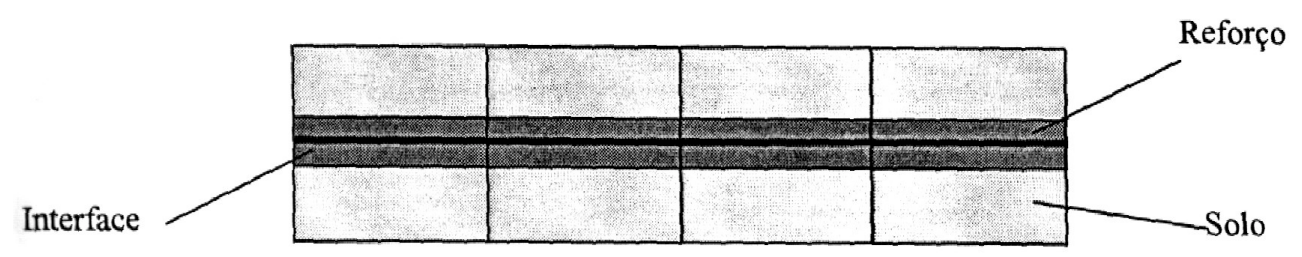

FIGURA 2.26 - Detalhe dos elementos da malha utilizando representação discreta (SILVA, 1998).

A representação composta supõe que não há deslocamentos relativos entre o reforço e o solo (CHANG \& FORSYTH, 1977). A elaboração da malha de elementos finitos fica facilitada porque as camadas de reforço são diretamente incorporadas nos elementos compostos, reduzindo substancialmente o tamanho da malha de elementos finitos e, consequentemente, o trabalho computacional. As desvantagens desta representação são a impossibilidade de, primeiro, modelar os deslocamentos relativos entre o reforço e o solo, segundo, estudar as tensões no reforço e, finalmente, modelar adequadamente o processo construtivo. Algumas tentativas têm sido feitas 
no sentido de se desenvolver elementos compostos que permitam o deslocamento relativo entre o solo e o reforço (NAYLOR \& RICHARDS, 1978). Entretanto, estes desenvolvimentos complicam o elemento composto, tornando o esforço computacional substancialmente maior, praticamente eliminando a vantagem da representação composta mencionada.

A representação discreta do solo reforçado fornece diretamente informações a respeito das deformações e tensões nas interfaces, no reforço, entre as camadas de reforço e na massa de solo. Além disto, permite a modelagem do deslocamento relativo entre o reforço e o solo, bem como a simulação adequada do processo construtivo.

Os programas de elementos finitos são, dentre todas as ferramentas disponíveis, as mais adequadas para prever os deslocamentos horizontais de estruturas de contenção reforçadas com geossintéticos. O grande desafio das análises numéricas é prever, quantitativamente, as tensões e os deslocamentos destas estruturas, na maioria das vezes, usando apenas os resultados de ensaios de laboratório realizados em seus materiais constituintes (geossintético e solo) ensaiados isoladamente (KARPURAPU \& BATHURST, 1995). Estes autores mostraram, através de simulações numéricas, que é possível prever com boa precisão o comportamento de uma estrutura de contenção tanto para condições de trabalho quanto para a de colapso utilizando apenas os resultados de ensaios realizados no solo e no geossintético isoladamente.

Dentre as várias vantagens, os programas de elementos finitos permitem realizar estudos paramétricos, explorando as relações entre o comportamento das estruturas em solo reforçado e as características dos seus elementos constituintes. Desta forma é possível ampliar o conhecimento do comportamento dessas estruturas através de análises em que se consideram as diferentes características de rigidez e de arranjos das inclusões e as particularidades de comportamento dos solos. 


\section{MATERIAIS E MÉTODOS}

\subsection{Introdução}

Este capítulo descreve os materiais utilizados na construção do protótipo executado na cidade de Nova Odessa-SP, o dimensionamento do protótipo, a instrumentação horizontal e vertical do mesmo e a sua modelagem numérica.

\subsection{Materiais utilizados}

\subsubsection{Solo}

Para caracterizar o solo utilizado na construção do protótipo foram realizados os ensaios de massa específica dos sólidos, limites de consistência, granulometria conjunta e compactação. A massa específica dos sólidos é igual a $2,646 \mathrm{~g} / \mathrm{cm}^{3}$ e o material foi classificado como não plástico (NP). A curva granulométrica está mostrada na Figura 3.1.

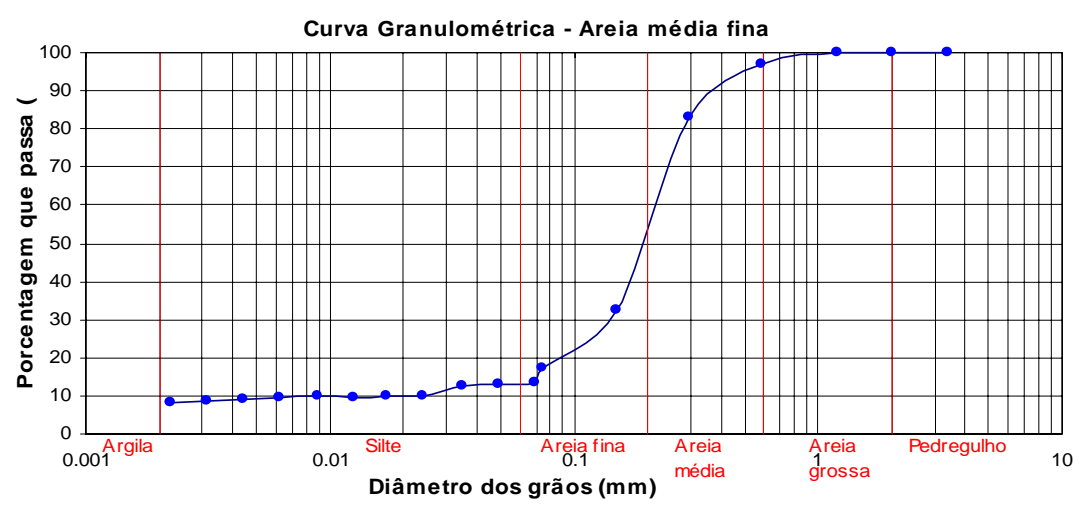

FIGURA 3.1 - Curva granulométrica do solo utilizado no protótipo. 
A partir da curva granulométrica, o solo foi classificado como uma areia média fina pouco argilosa. Foi realizado, também, o ensaio de compactação com a energia de Proctor Normal, cuja curva de compactação está mostrada na Figura 3.2. Os parâmetros de compactação, teor de umidade ótimo e massa específica seca máxima, atingiram $9,0 \%$ e $1,878 \mathrm{~g} / \mathrm{cm}^{3}$, respectivamente.

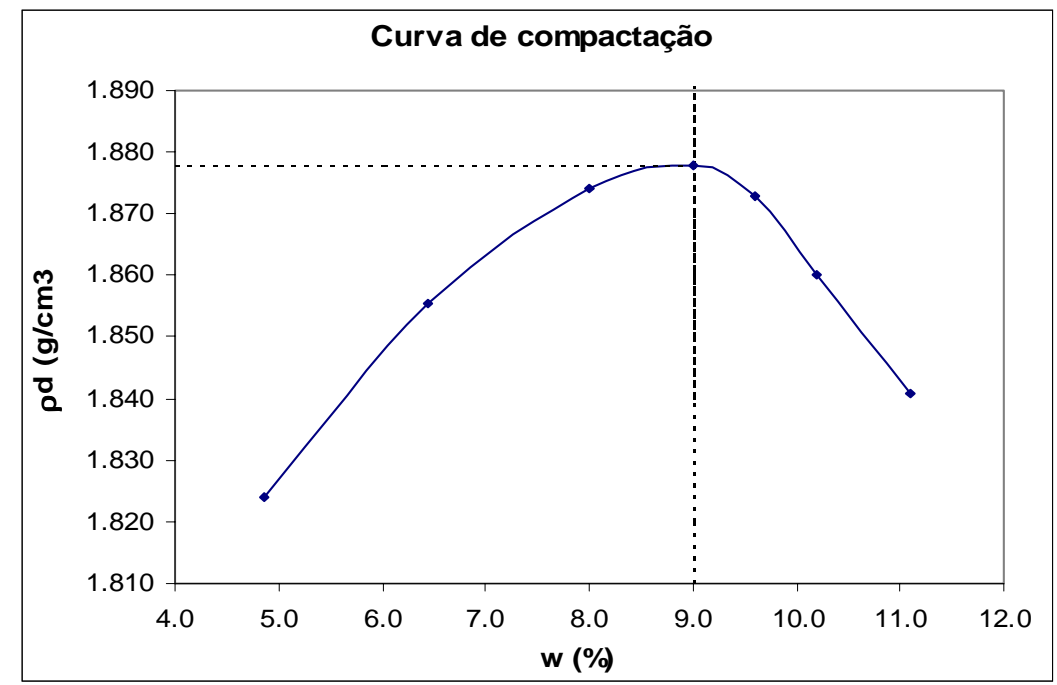

FIGURA 3.2 - Curva de compactação do solo utilizado no protótipo.

Além destes ensaios, foram realizados três ensaios triaxiais do tipo adensado drenado com tensões confinantes de 25, 50 e 100kPa. Para realizar estes ensaios foram compactados três corpos de prova com grau de compactação e teor de umidade de $95 \%$ e $9 \%$, respectivamente. As características dos corpos de prova após serem compactados estão mostradas na Tabela 3.1. Pode-se observar que os três corpos de prova apresentam graus de compactação e teores de umidade bem próximos dos valores especificados.

TABELA 3.1 - Características dos corpos de prova utilizados nos ensaios triaxiais.

\begin{tabular}{|c|c|c|c|c|c|c|c|}
\hline $\mathbf{C . P .}$ & $(\mathbf{k P a})$ & $\left(\mathbf{c m}^{\mathbf{3}}\right)$ & $(\mathbf{g})$ & $\begin{array}{c}\mathbf{\rho} \\
\left(\mathbf{g} / \mathbf{c m}^{3}\right)\end{array}$ & $\begin{array}{c}\mathbf{w} \\
(\mathbf{\%})\end{array}$ & $\begin{array}{c}\rho_{\mathbf{d}} \\
\left(\mathbf{g} / \mathbf{c m}^{\mathbf{3}}\right)\end{array}$ & $\begin{array}{c}\mathbf{G C} \\
(\boldsymbol{\%})\end{array}$ \\
\hline $\mathbf{0 1}$ & 25 & 254,69 & 496,14 & 1,948 & 9,12 & 1,785 & 95,05 \\
\hline $\mathbf{0 2}$ & 50 & 254,72 & 495,94 & 1,947 & 8,93 & 1,787 & 95,15 \\
\hline $\mathbf{0 3}$ & 100 & 254,65 & 497,34 & 1,953 & 8,74 & 1,796 & 95,63 \\
\hline
\end{tabular}


Os ensaios triaxiais CD foram realizados para se obter os parâmetros do modelo hiperbólico e a envoltória de resistência ao cisalhamento do solo. A obtenção dos parâmetros do modelo hiperbólico pode ser encontrada em DUNCAN \& CHANG (1970). O solo utilizado na construção do protótipo foi denominado de Odessa e os valores dos parâmetros do modelo hiperbólico estão apresentados na Tabela 3.2.

TABELA 3.2 - Parâmetros do modelo hiperbólico para o solo usado no protótipo.

\begin{tabular}{|l|c|c|c|c|c|c|c|c|c|c|}
\hline Parâmetros & $\begin{array}{c}\boldsymbol{\gamma} \\
\left(\mathbf{k N} / \mathbf{m}^{\mathbf{3}}\right)\end{array}$ & $\mathbf{K}$ & $\mathbf{N}$ & $\mathbf{R f}$ & $\mathbf{K b}$ & $\mathbf{m}$ & $\begin{array}{c}\mathbf{c} \\
(\mathbf{k P a})\end{array}$ & $\boldsymbol{\phi}\left(^{\mathbf{0}}\right)$ & $\mathbf{K o}$ & $\mathbf{K u r}$ \\
\hline Odessa & 17,8 & 963 & 0,42 & 1,00 & 212,4 & 0,00 & 9,7 & 34 & 0,44 & 1445 \\
\hline
\end{tabular}

Onde:

$\gamma$ - peso específico do solo;

$\mathrm{K}$ - número do módulo de rigidez do solo;

$\mathrm{n}$ - expoente do módulo de rigidez;

$\mathrm{R}_{\mathrm{f}}$ - Coeficiente de ruptura;

$\mathrm{K}_{\mathrm{b}}$ - número do módulo volumétrico;

$\mathrm{m}$ - expoente do módulo volumétrico;

c - coesão drenada do solo;

$\phi$ - ângulo de atrito do solo;

$\mathrm{K}_{\mathrm{o}}$ - coeficiente de empuxo em repouso;

$\mathrm{K}_{\mathrm{ur}}$ - número do módulo de rigidez para o carregamento e descarregamento;

As curvas (tensão $\mathrm{x}$ deformação) experimentais e previstas pelo modelo hiperbólico estão mostradas na Figura 3.3. Para a tensão confinante de $25 \mathrm{kPa}$ observou-se que a partir da deformação de 3\% os valores do modelo ficaram um pouco maiores que os experimentais. Com a tensão confinante de $50 \mathrm{kPa}$ e $100 \mathrm{kPa}$ o modelo se aproximou muito bem do experimental até cerca de $90 \%$ e $75 \%$ da tensão de ruptura do solo, respectivamente. A partir destes pontos observa-se que os valores do modelo ficaram um pouco menores que o dos experimentais. Como se percebe, o modelo hiperbólico prevê com bastante precisão o comportamento do solo. 


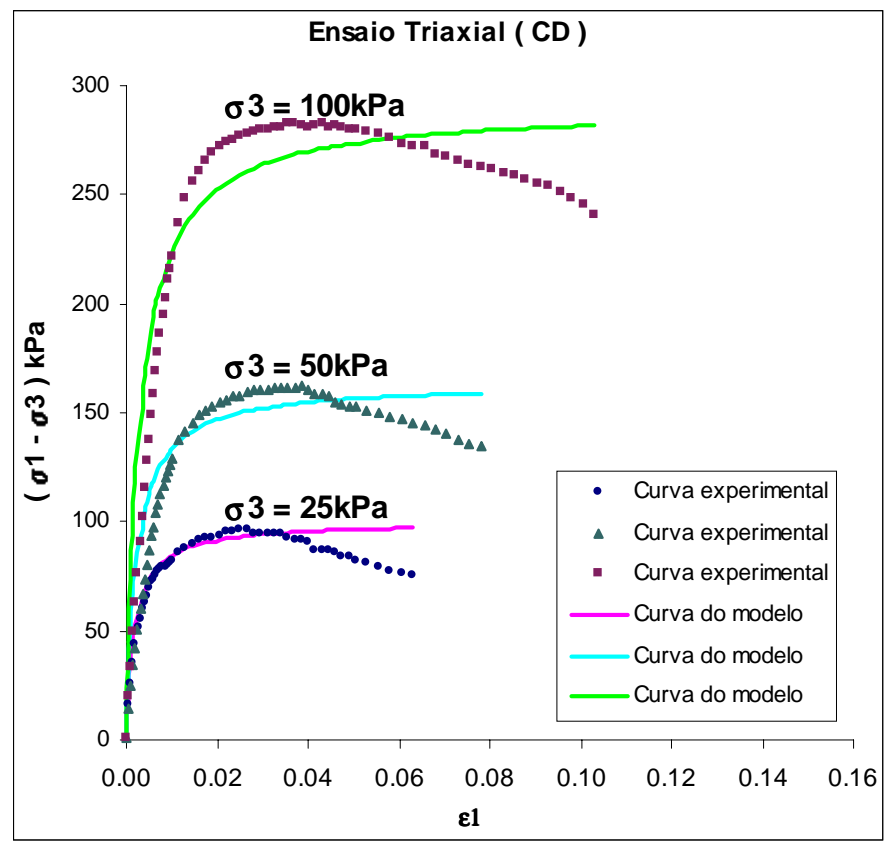

FIGURA 3.3 - Resultados dos ensaios triaxiais CD e do modelo hiperbólico.

\subsubsection{Geotêxtil}

O geotêxtil utilizado na construção do protótipo foi do tipo não tecido agulhado (Geofort G-400). Foram realizados ensaios de gramatura, espessura nominal e tração cujos resultados estão apresentados na Tabela 3.3.

TABELA 3.3 - Propriedades do geotêxtil não tecido agulhado

\begin{tabular}{|c|c|}
\hline Gramatura & $400 \mathrm{~g} / \mathrm{m}^{2}$ \\
\hline Espessura nominal & $3,8 \mathrm{~mm}$ \\
\hline Resistência à tração longitudinal & $24,75 \mathrm{kN} / \mathrm{m}$ \\
\hline Resistência à tração transversal & $25,70 \mathrm{kN} / \mathrm{m}$ \\
\hline Módulo secante (5\% de deformação) & $40 \mathrm{kN} / \mathrm{m}$ \\
\hline
\end{tabular}

\subsection{Dimensionamento do protótipo}

A estrutura de contenção foi dimensionada segundo o método convencional de análise (MITCHELL E VILLET, 1987) conforme descrito no item 2.2.3.1.

Os fatores de redução e de segurança que foram utilizados no dimensionamento do protótipo estão apresentados na Tabela 3.4. 
TABELA 3.4 - Fatores de redução e fatores de segurança para a estabilidade interna.

\begin{tabular}{|c|c|}
\hline Fatores de redução & FR \\
\hline Danos de instalação & 1,5 \\
\hline Fluência & 1,0 \\
\hline Degradação química & 1,0 \\
\hline Degradação biológica & 1,0 \\
\hline Fatores de segurança & FS \\
\hline Quebra & 1,3 \\
\hline Arrancamento & 1,3 \\
\hline
\end{tabular}

Adotou-se um fator de redução quanto à fluência igual a 1,0 para verificar a evolução dos deslocamentos com o tempo. Foi adotado um fator de segurança quanto à ruptura do reforço de 1,3 que levou a espaçamentos verticais de $0,50 \mathrm{~m}$, sendo a primeira camada a ficha. Isto gerou um total de nove camadas de geotêxtil. $\mathrm{O}$ fator de segurança mínimo quanto ao arrancamento foi de 1,3 e, com isto, obteve-se um comprimento de reforço de 3,0m para todas as inclusões. A geometria final da estrutura de contenção está mostrada na Figura 3.4.

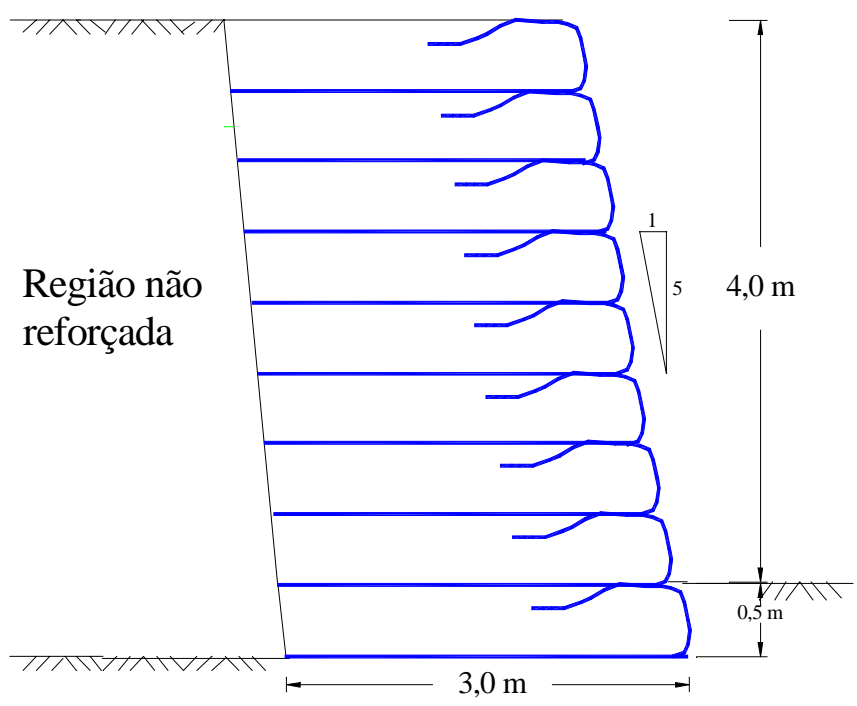

FIGURA 3.4 - Geometria do protótipo após o seu dimensionamento.

\subsection{Construção do protótipo}

O protótipo foi construído em uma cava feita em uma encosta. A altura, o comprimento e a largura do protótipo atingiram $4 \mathrm{~m}, 4 \mathrm{~m}$ e $3 \mathrm{~m}$, respectivamente. A altura do protótipo foi imposta pela altura da encosta e o seu comprimento foi tomado para que a relação entre a altura da estrutura e o seu comprimento fosse igual a 1,0. Com isto, garante-se um estado plano de deformação na parte central da 
estrutura. As Figuras 3.5 e 3.6 mostram a colocação da manta de geotêxtil e a compactação de uma camada típica de solo com uma placa vibratória.

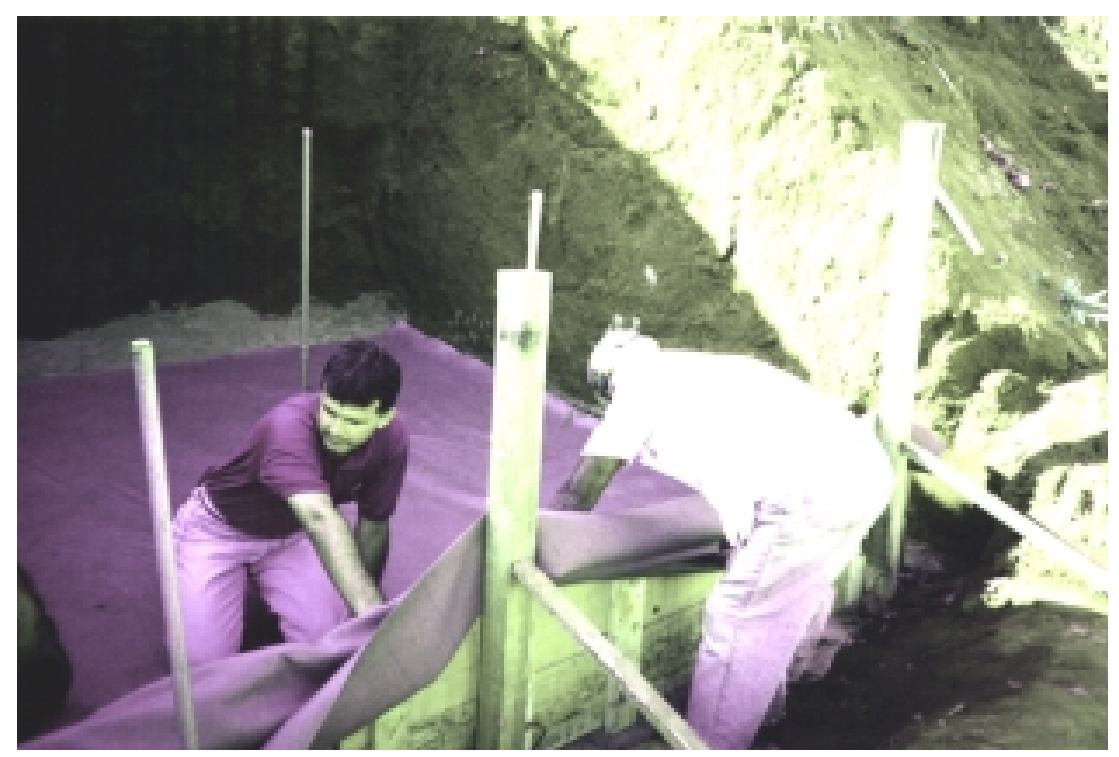

FIGURA 3.5 - Colocação da primeira manta de geotêxtil.

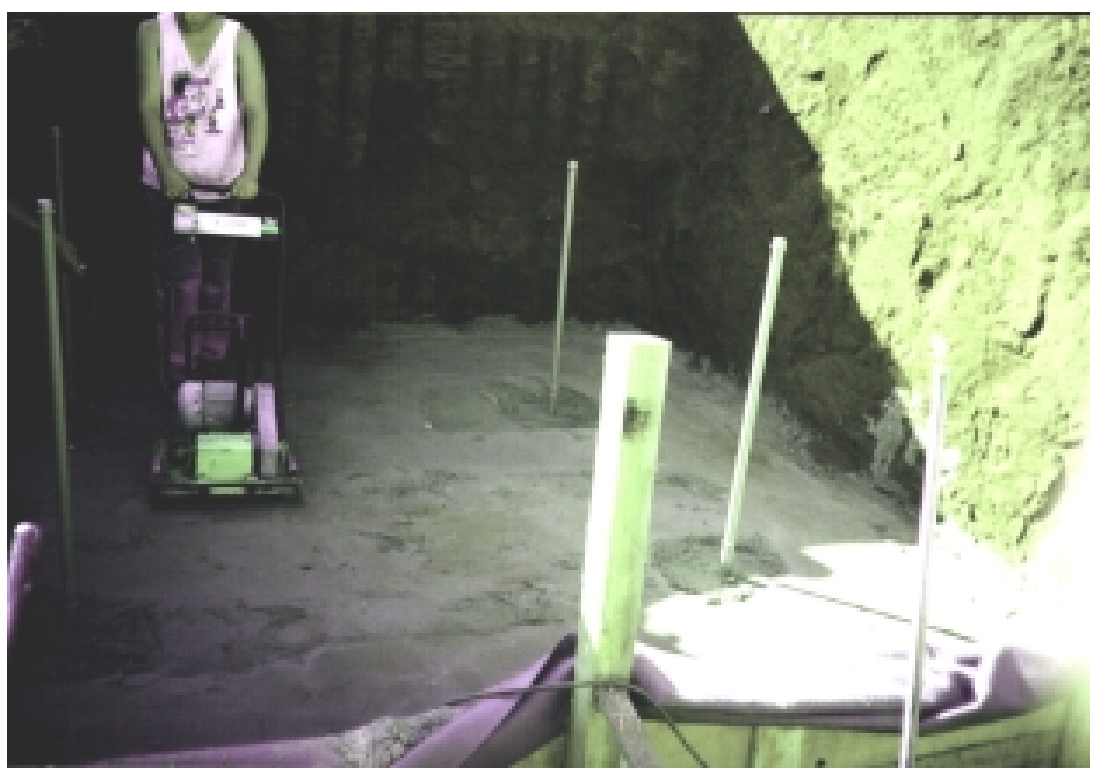

FIGURA 3.6 - Compactação da camada de solo com uma placa vibratória.

Para uma maior eficiência da compactação, as camadas de solo entre as inclusões foram compactadas em três sub-camadas sucessivas de $17 \mathrm{~cm}$ de espessura, depois de acabadas. Nas quatro primeiras camadas foram verificados os graus de compactação e os teores de umidade e obtiveram-se os valores médios de $93 \%$ e $6 \%$, respectivamente. 


\subsection{Instrumentação}

\subsubsection{Instrumentação horizontal}

Para monitorar os deslocamentos horizontais do muro foram empregadas barras de aço trefilado de $9,5 \mathrm{~mm}$. Os comprimentos foram determinados de acordo com as dimensões da superfície de ruptura hipotética de Rankine, a qual forma um ângulo de $\left(45^{\circ}+\phi / 2\right)$ com a horizontal. Os comprimentos das barras foram calculados, de forma que, em cada nível de instrumentação, houvesse uma barra (de comprimento menor) dentro da cunha, uma (com comprimento médio) fora da cunha e uma outra (de maior comprimento) fora da zona reforçada denominada barra de referência (Figura 3.7).

Planta da instrumentação

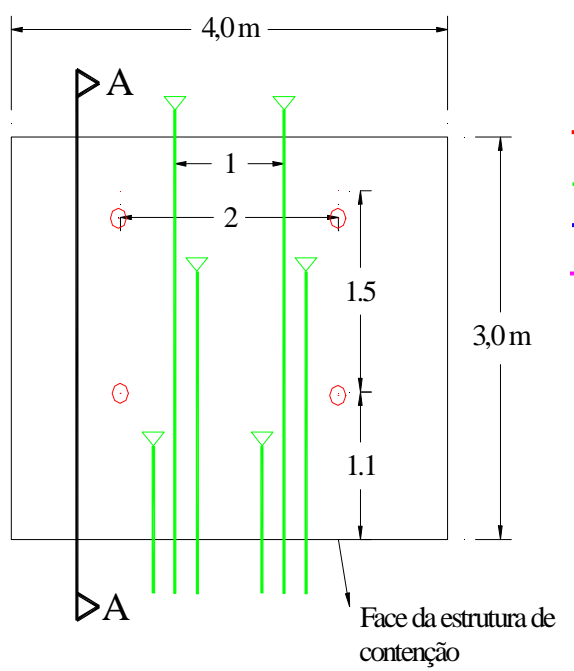

Corte transversal AA

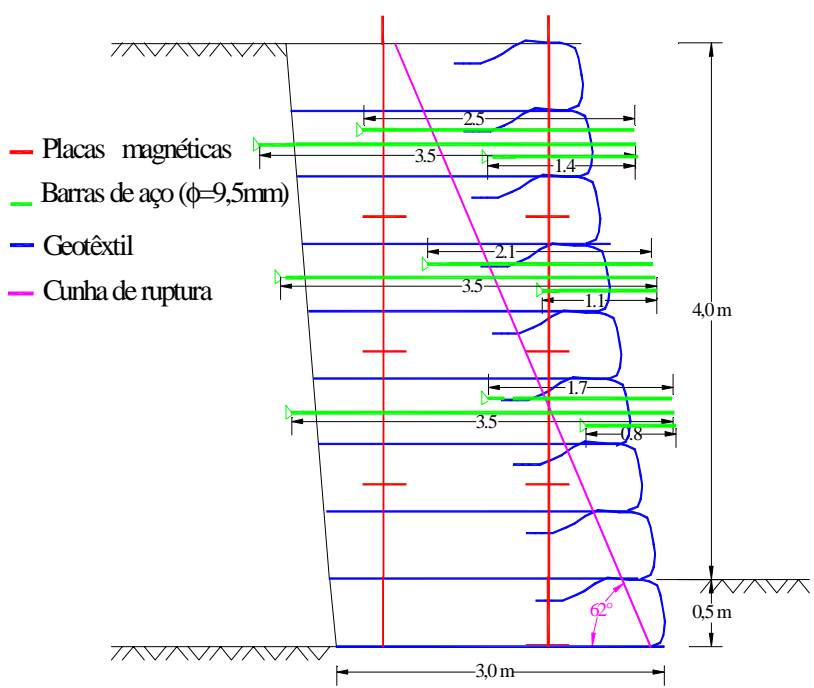

FIGURA 3.7 - Planta e Corte da instrumentação horizontal e vertical.

As barras foram dispostas horizontalmente dentro de tubos de PVC de $25 \mathrm{~mm}$ para diminuir o atrito com o solo circundante (Figura 3.8). Além disto, elas foram dobradas na extremidade interior para garantir uma melhor ancoragem ao solo. As barras ficaram salientes em relação à face do muro em cerca de $20 \mathrm{~cm}$. Para fazer as leituras dos deslocamentos em cada barra mede-se a distância entre uma marca feita em sua extremidade externa e uma marca similar feita na barra de referência que é ancorada, com concreto, fora da zona reforçada. Assim, os deslocamentos 
horizontais são sempre relativos à marca desta barra de referência. Com um paquímetro mede-se a distância entre as marcas de cada uma e a marca de referência. Desta forma, foram obtidas as leituras dos deslocamentos das barras dentro e fora de uma cunha hipotética de ruptura.

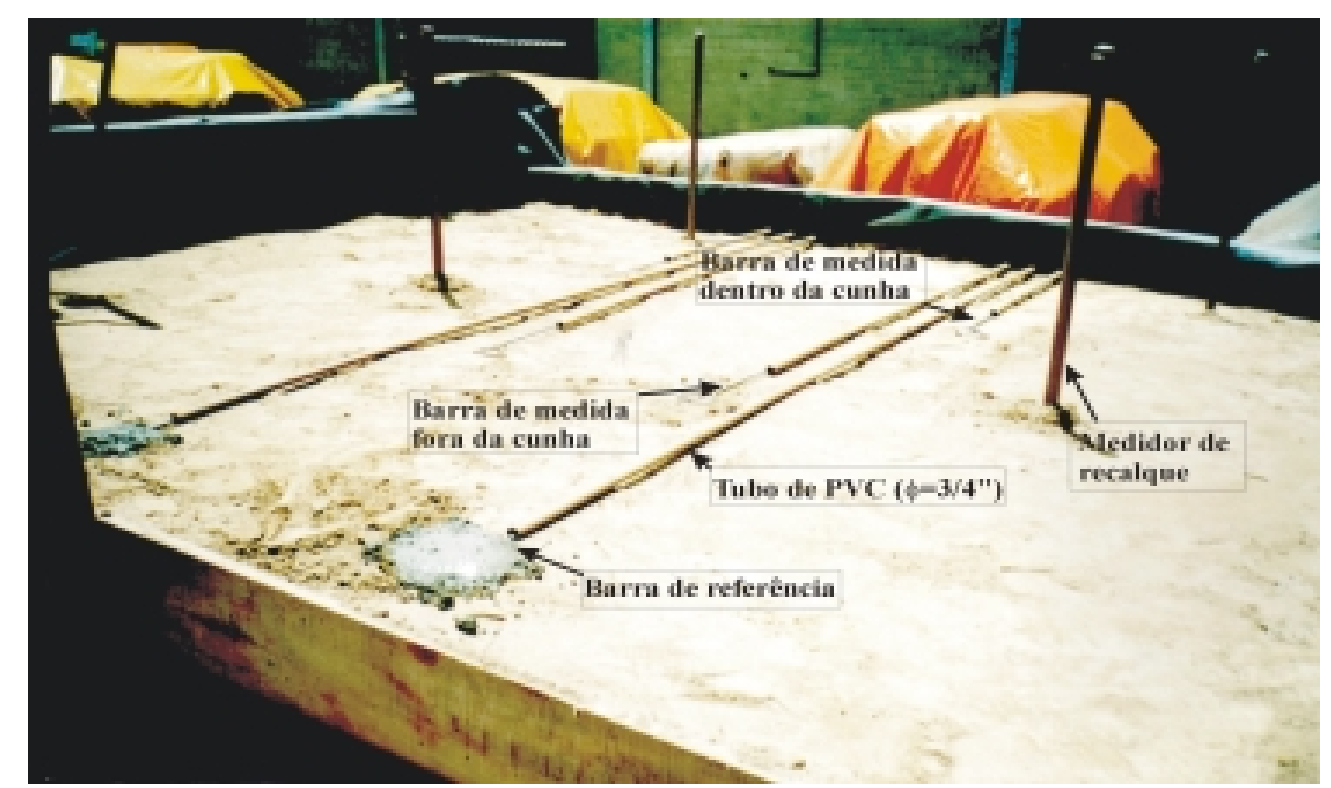

FIGURA 3.8 - Execução da instrumentação horizontal dentro do maciço reforçado.

\subsubsection{Instrumentação vertical}

A instrumentação vertical, construída especialmente para este trabalho, consistiu de uma bateria de placas magnéticas de recalque acopladas em tubos de PVC de $32 \mathrm{~mm}$ e $40 \mathrm{~mm}$ (Figura 3.9). Estas placas são quadradas com $20 \mathrm{~cm}$ de lado e, também, são feitas de PVC. Sobre cada uma delas apoia-se um ímã, formando um transdutor magnético. As baterias foram posicionadas no maciço de forma que duas ficassem próximas à face, dentro da cunha de ruptura hipotética de Rankine, e as outras duas fora desta cunha.

A leitura dos recalques foram efetuadas introduzindo-se no tubo de PVC uma haste graduada de alumínio que possui um "reed switch" na ponta. Ao se aproximar do ímã, fecha-se um circuito elétrico que aciona o indicador sonoro de um multímetro ligado ao sensor. O indicador sonoro é acionado quando a ponta da haste se aproxima do ímã. Por isto, as leituras foram realizadas quando o indicador sonoro parava de apitar. Neste momento, a ponta da haste passava exatamente pelo centro do 
ímã, onde o campo magnético é nulo, por causa disto, o indicador sonoro parava de apitar. Bastava, então, neste ponto fazer a leitura na haste graduada. O recalque é a diferença entre duas leituras efetuadas antes e após ocorrer o deslocamento vertical. Todas as placas de recalque foram calibradas e apresentaram precisão de $\pm 3 \mathrm{~mm}$. A Figura 3.10 mostra o detalhe do tubo de PVC com a placa magnética acoplada.

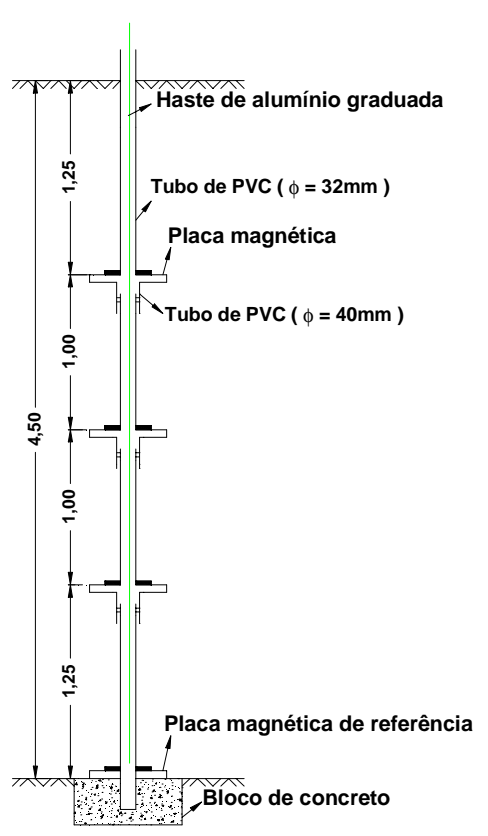

FIGURA 3.9 - Medidor de recalque.

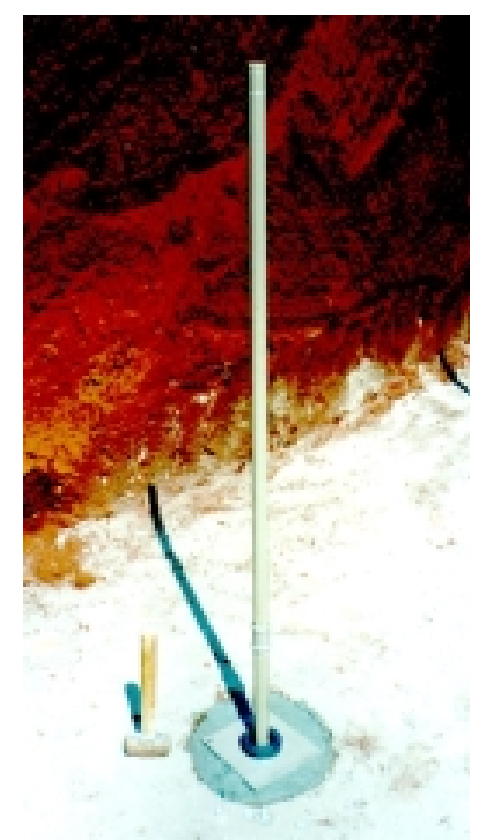

FIGURA 3.10 - Módulo de PVC com a placa magnética acoplada.

\subsection{Modelagem numérica do protótipo}

As simulações numéricas foram realizadas utilizando o programa de elementos finitos SSCOMPPC (BOULANGER et al. 1991). A malha de elementos finitos usada na simulação do protótipo está apresentada na Figura 3.11. Ela consistiu de 245 nós, 212 elementos de solo de 4 nós e 48 elementos de barra, para modelar as inclusões. O modelo de comportamento (tensão x deformação) do solo empregado no programa SSCOMPPC é o não linear hiperbólico proposto por DUNCAN \& CHANG (1970). As inclusões foram modeladas como materiais elásticos lineares (BOULANGER et al. 1991).

Assumiu-se uma aderência perfeita entre o solo e o geotêxtil, ou seja, não foram utilizados elementos de junta para representar a interface entre o solo e o 
reforço. EHRLICH \& MITCHELL (1994) mostraram que, em geral, existe aderência perfeita entre o geotêxtil e o solo em condições de tensões de trabalho. CHALATURNYK \& SCOTT (1990) também assumiram aderência perfeita entre o solo e o geotêxtil, devido ao fato das tensões cisalhantes serem muito pequenas para causarem deslizamento na interface solo-geotêxtil.

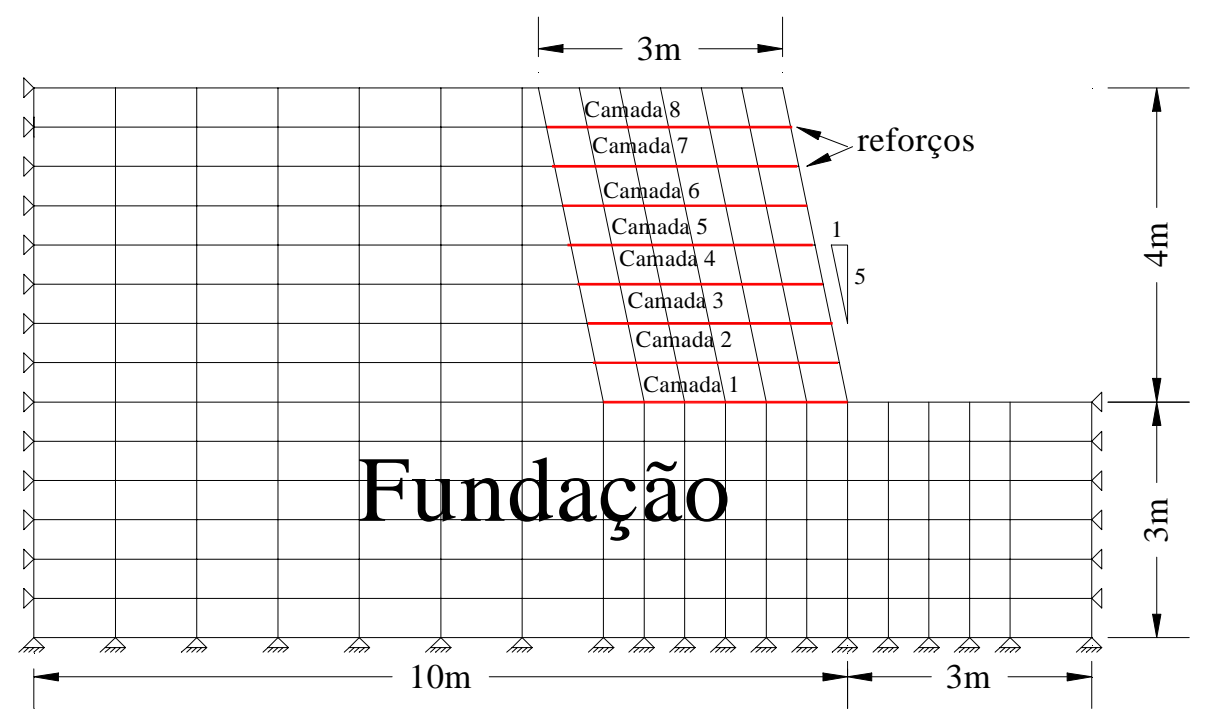

FIGURA 3.11 - Malha de elementos finitos usada nas simulações do protótipo.

O programa utilizado não tem a opção de corrigir a malha devido aos deslocamentos em cada etapa de lançamento das camadas. Por causa desta limitação, os deslocamentos horizontais máximos da face se localizavam à meia altura da estrutura, não correspondendo com a realidade. Para resolver este problema, a malha foi corrigida para cada camada seguindo o roteiro descrito a seguir. A primeira camada, da malha de elementos finitos, foi lançada e em seguida executou-se o programa. Com isto, obteve-se todos os deslocamentos e tensões devido ao lançamento desta camada. Uma outra malha de elementos finitos foi feita, corrigindo a sua geometria, conforme os deslocamentos da primeira camada (FIGURA 3.12). Com a primeira camada corrigida lançou-se a segunda camada sobre a primeira. Em seguida, executou-se o programa desprezando o peso próprio da primeira camada. Isto foi feito para que a primeira camada não se deforme, novamente, pelo efeito do seu peso próprio. Isto se repetiu até o lançamento da última camada. 


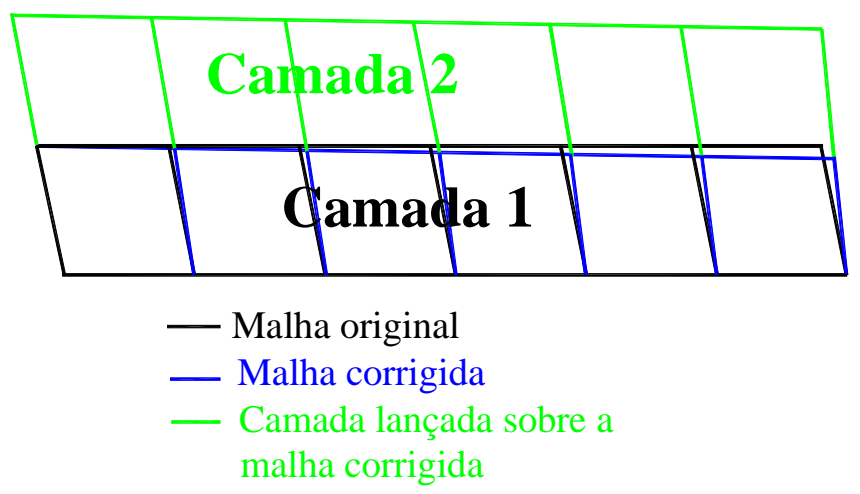

FIGURA 3.12 - Lançamento e correção das duas primeiras camadas da malha.

Esta deficiência do programa foi também detectada por ZORNBERG (1994) que efetuou correções para obter os deslocamentos horizontais da face. 


\section{APRESENTAÇÃO E DISCUSSÃO DOS RESULTADOS}

\subsection{Introdução}

Este capítulo descreve os resultados dos deslocamentos horizontais e verticais medidos ao final da construção do protótipo e ao longo do tempo. Além disto, serão apresentadas as tensões, deformações e distribuições das forças de tração calculadas pela simulação do protótipo. Em seguida, serão apresentados os resultados das análises paramétricas e resultados de obras instrumentadas publicados na literatura.

\subsection{Resultados do protótipo}

\subsubsection{Deslocamentos horizontais do protótipo}

Os resultados experimentais e numéricos serão apresentados tomando-se como referência a Figura 4.1 .

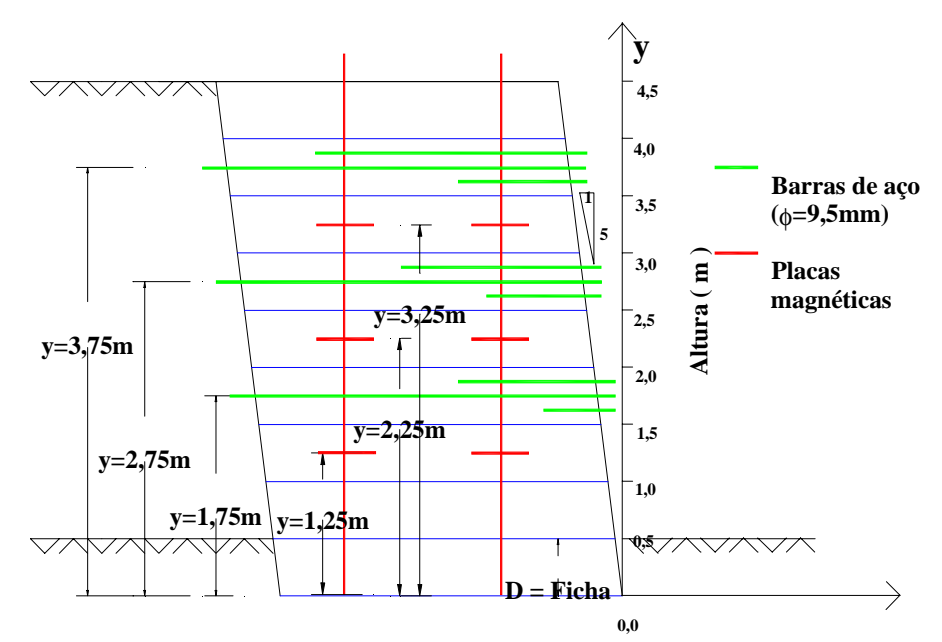

FIGURA 4.1 - Estrutura de referência para a apresentação dos resultados. 
Os deslocamentos horizontais, dentro e fora da cunha de ruptura, obtidos da instrumentação e da simulação do protótipo, estão apresentados nas Figuras 4.2 e 4.3. Estes deslocamentos foram medidos no final da construção do protótipo.

Os deslocamentos horizontais medidos dentro da cunha hipotética de ruptura atingiram valores máximos de $22 \mathrm{~mm}$, enquanto que os deslocamentos medidos fora da cunha atingiram apenas $5 \mathrm{~mm}$. Isto mostra que os movimentos próximos à face são bem maiores que aqueles mais distantes, o que pode ser um indicativo da formação de uma cunha de ruptura.

Os deslocamentos dos pontos dentro dessa cunha, calculados pela simulação, atingiram cerca de $18 \mathrm{~mm}$. A diferença entre os deslocamentos medidos e os simulados atingiu 13\%. ZORNBERG (1994) também obteve deslocamentos horizontais menores que os medidos e sua diferença atingiu $14 \%$, enquanto KARPURAPU \& BATHURST (1995) também obtiveram deslocamentos horizontais menores que os medidos com diferença de $16 \%$. Do exposto, pode-se concluir que a simulação realizada fornece deslocamentos de mesma ordem de grandeza dos deslocamentos medidos e que este padrão de comportamento se ajusta ao de alguns resultados publicados na literatura.

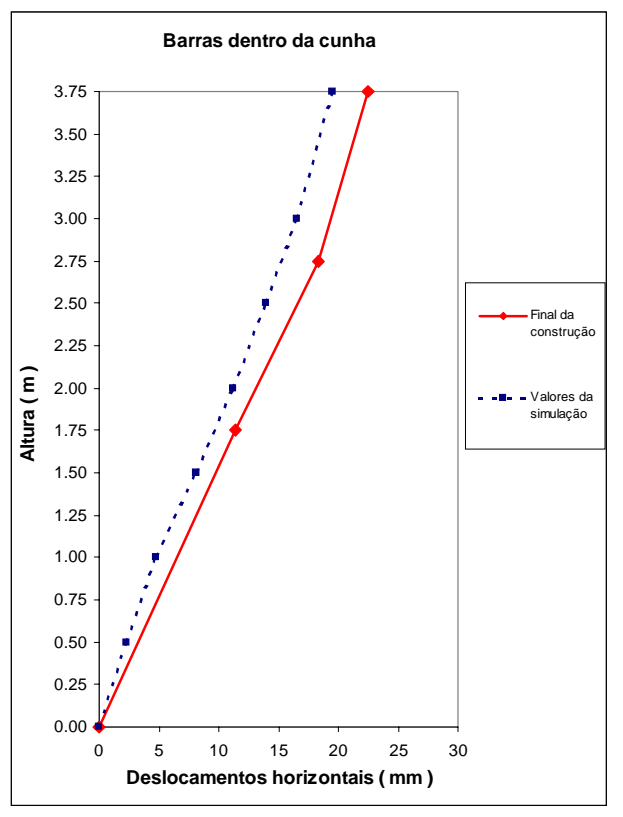

FIGURA 4.2 - Deslocamentos horizontais dentro da cunha.

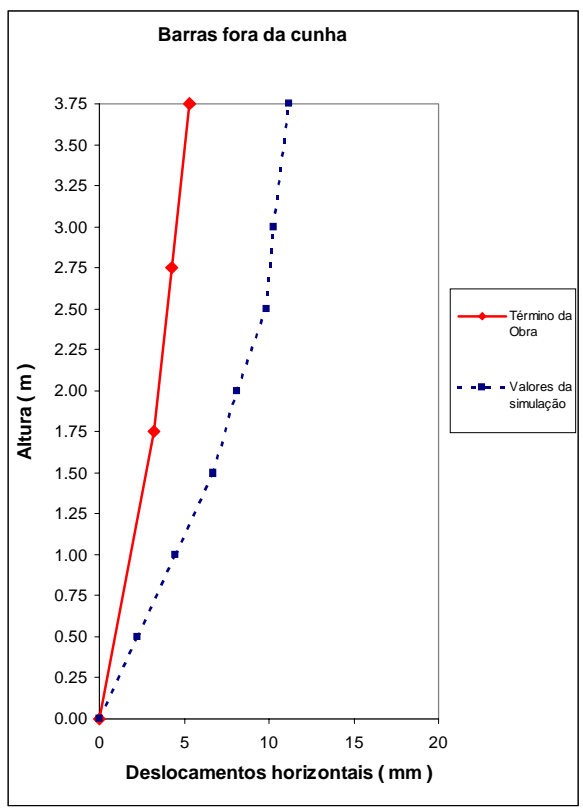

FIGURA 4.3-Deslocamentos horizontais fora da cunha.

Uma comparação entre os resultados mostrados nas Figuras 4.2 e 4.3 mostram que a simulação numérica previu com mais exatidão os resultados dos deslocamentos dentro da cunha. 
As Figuras 4.4 e 4.5 mostram os deslocamentos horizontais medidos ao longo do tempo para as barras dentro e fora da cunha, respectivamente. Estas barras foram posicionadas a 1,$75 ; 2,75$ e $3,75 \mathrm{~m}$ de altura. Nota-se que os deslocamentos horizontais cresceram da base para o topo da estrutura.

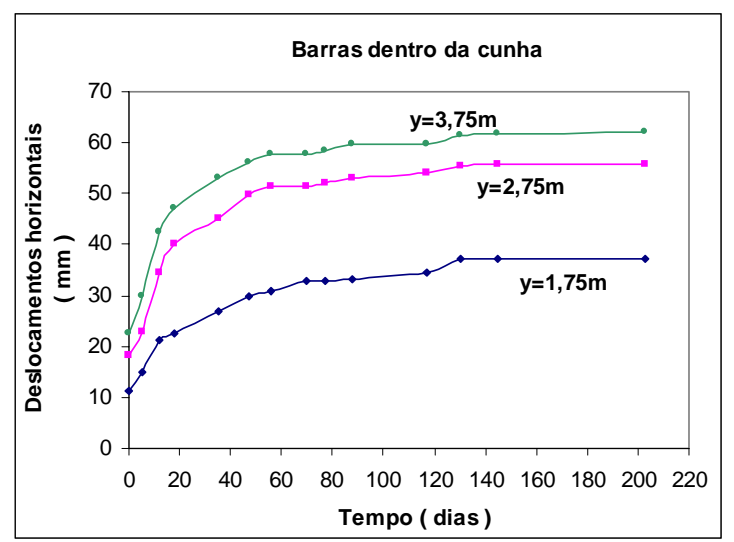

FIGURA 4.4-Deslocamentos horizontais ao longo do tempo dentro da cunha.

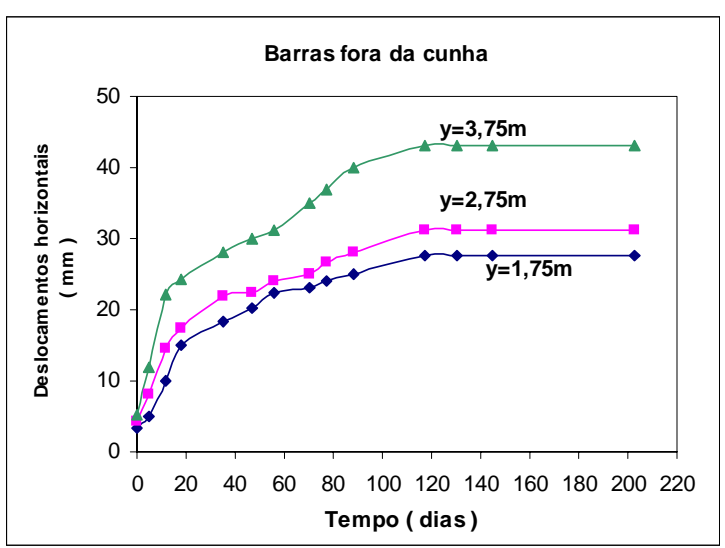

FIGURA 4.5-Deslocamentos horizontais ao longo do tempo fora da cunha.

O deslocamento horizontal máximo $\left(\delta_{\text {máx }}\right)$, dentro da cunha, ocorrido após 202 dias do final da construção atingiu $62 \mathrm{~mm}$, enquanto que o máximo ao final da construção atingiu $22 \mathrm{~mm}$. Isto mostra que na fase pós-construção os deslocamentos horizontais são bastante maiores devido, possivelmente, ao efeito da fluência do geotêxtil. Após 120 dias do final da construção observa-se, para todas as barras, uma estabilização dos deslocamentos medidos. A relação entre o deslocamento máximo após 202 dias do final da construção e a altura da estrutura $\left(\delta_{\text {máx }} / \mathrm{H}\right)$ atingiu cerca de 1,5\%. Este deslocamento pode ser considerado de pequena magnitude tendo em vista que o fator de redução devido à fluência foi tomado igual à unidade.

\subsubsection{Deslocamentos verticais do protótipo}

Os resultados dos deslocamentos verticais medidos ao final da construção do protótipo e calculados pela simulação numérica estão mostrados nas Figuras 4.6 e 4.7. Os deslocamentos verticais medidos e simulados, dentro da cunha, atingiram cerca de 8 e $15 \mathrm{~mm}$, respectivamente. Enquanto os deslocamentos verticais medidos e simulados, fora da cunha, atingiram cerca de 5 e $11 \mathrm{~mm}$, respectivamente. Do 
exposto, pode-se observar que no final da construção do protótipo os deslocamentos verticais medidos estão menores que os simulados.

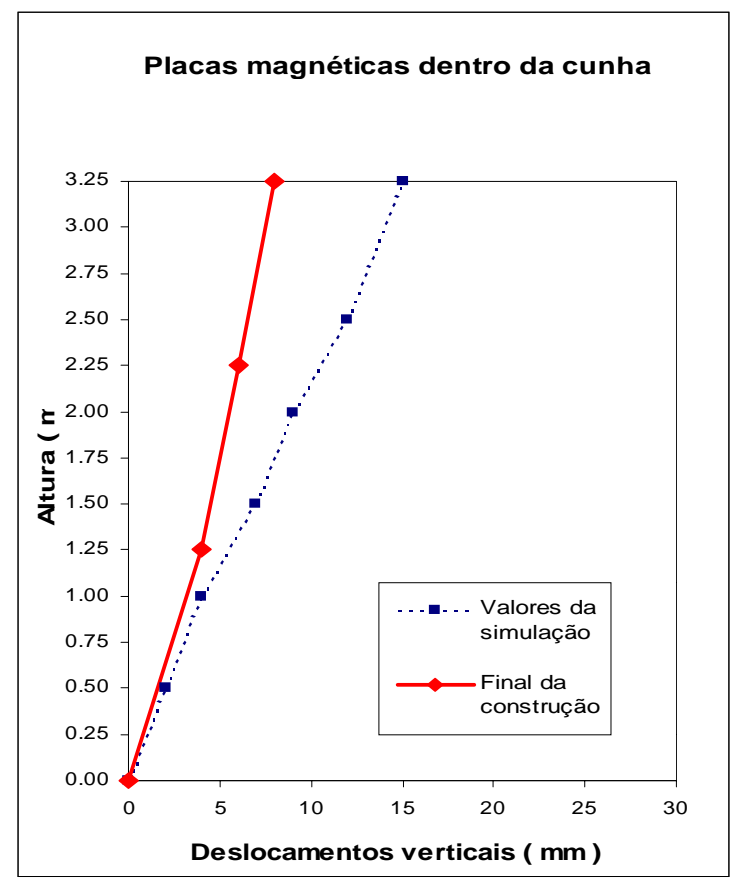

FIGURA 4.6 - Deslocamentos verticais dentro da cunha.

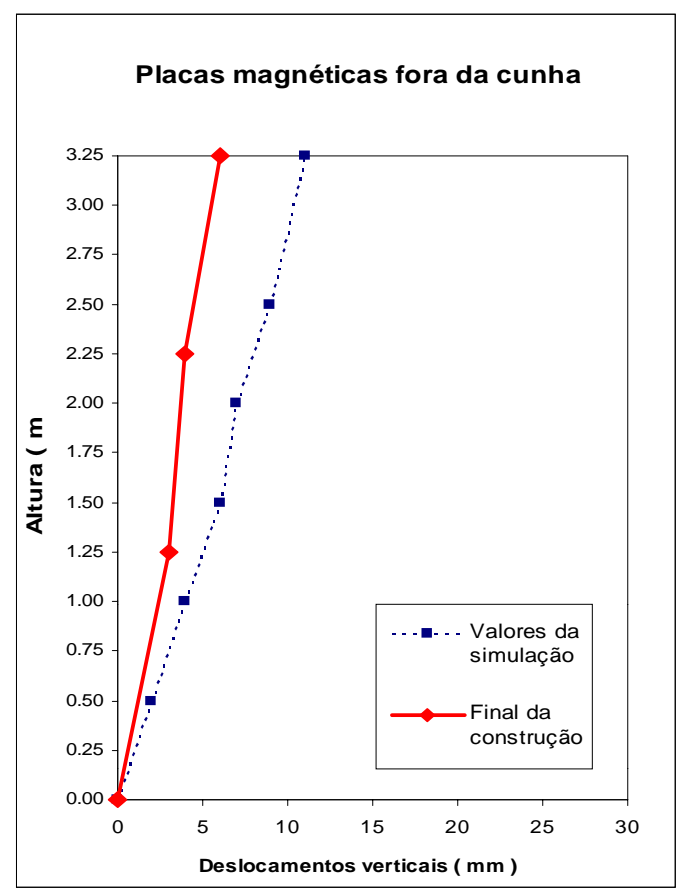

FIGURA 4.7 - Deslocamentos verticais fora da cunha.

As Figuras 4.8 e 4.9 mostram os deslocamentos verticais medidos. As placas foram posicionadas a 1,$25 ; 2,25$ e $3,25 \mathrm{~m}$ de altura. Nota-se que os deslocamentos verticais são, também, crescentes da base para o topo da estrutura.

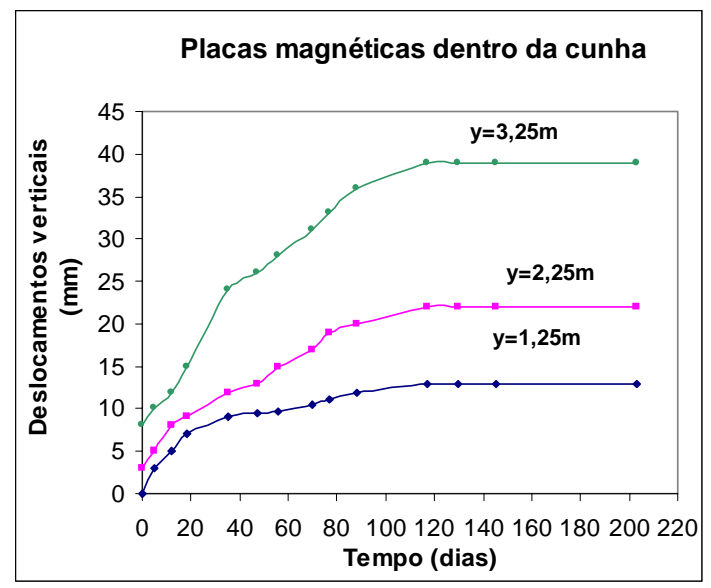

FIGURA 4.8 - Deslocamentos verticais ao longo do tempo dentro da cunha.

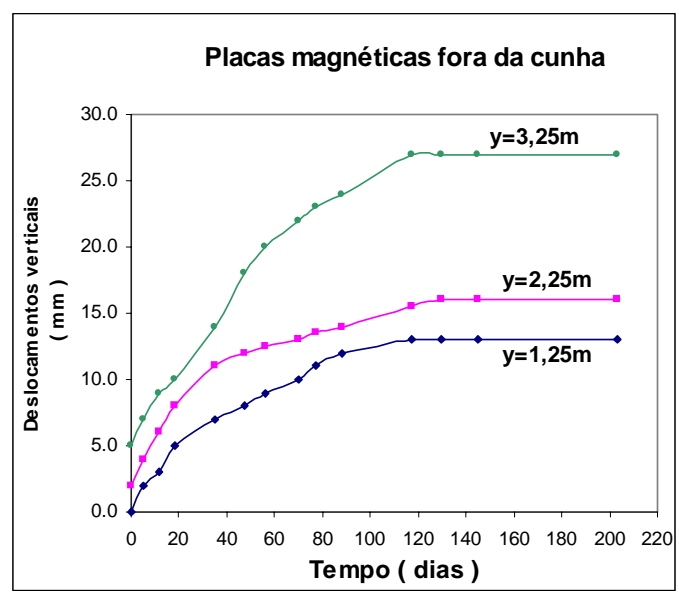

FIGURA 4.9 - Deslocamentos verticais ao longo do tempo fora da cunha. 
O deslocamento vertical, dentro da cunha, ocorrido após 202 dias do final da construção atingiu cerca de $38 \mathrm{~mm}$, enquanto o deslocamento no final da construção atingiu apenas $8 \mathrm{~mm}$. O deslocamento vertical, fora da cunha, ocorrido após 202 dias do final da construção e no final da construção atingiram $27 \mathrm{~mm}$ e $5 \mathrm{~mm}$, respectivamente. Nota-se que os deslocamentos dentro da cunha foram maiores indicando, também, a formação da cunha de ruptura. Além disto, observa-se que na fase pós-construção os deslocamentos verticais são bastante maiores. Fatores como a fluência do geotêxtil e sobrecargas de tráfego não previstas, e que foram aplicadas bem próximas da zona reforçada, devem ser os fatores responsáveis por tal comportamento. No entanto, após 120 dias do final da construção, os recalques em todos os níveis de observação se estabilizaram.

\subsubsection{Resultados das tensões e deformações obtidas das simulações}

A avaliação das tensões e deformações atuantes em uma estrutura de contenção em solo reforçado são essenciais para se quantificar os esforços nos seus elementos constituintes e para prever o mecanismo de ruptura. As tensões registradas neste trabalho referem-se somente às devidas aos esforços de peso próprio do solo.

Pode-se notar da análise da Figura 4.10 que próximo à face as tensões verticais reduzem-se quando comparadas com as tensões devido ao peso próprio. Mais para o interior do maciço, elas tornam-se constantes. Isto ocorre à uma distância de cerca de L/2, sendo L o comprimento da inclusão. Esta redução de tensões verticais deve-se à plastificação do maciço que possui liberdade para deformar-se lateralmente pela ausência de face.

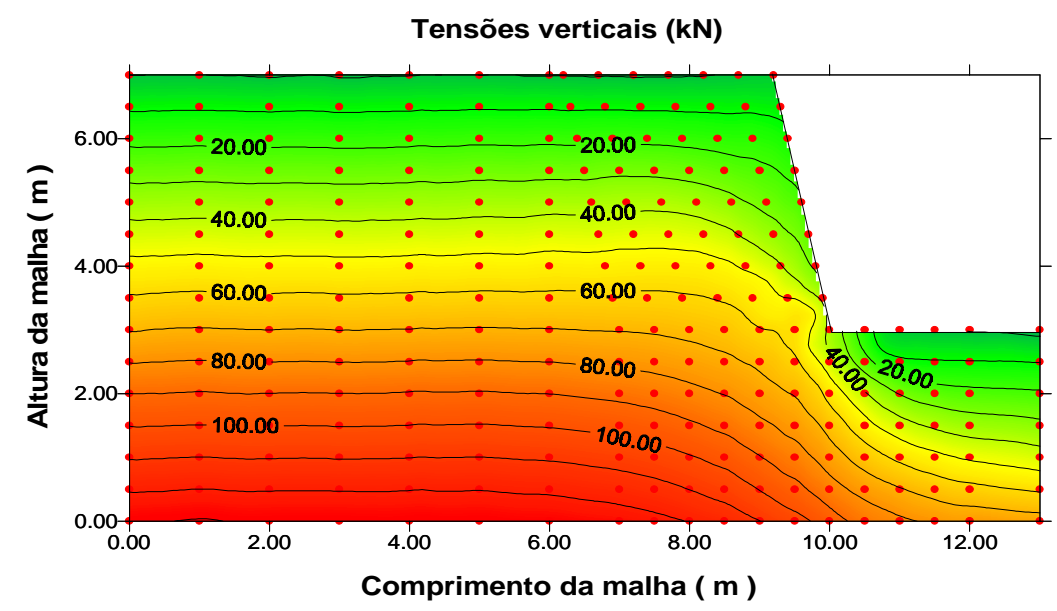

FIGURA 4.10 - Tensões verticais atuantes na estrutura de contenção. 
ROSCOE (1970) mostrou que as deformações cisalhantes em estruturas de contenção são despertadas quando se permite deslocamentos do solo do maciço arrimado. Para o caso de rotação em torno do pé da estrutura, ele observou que a formação de deformações cisalhantes obedece a um processo contínuo que se inicia na base da estrutura e se atenua próximo do seu topo.

No protótipo observou-se uma rotação em torno do pé. Isto originou os contornos de deformações cisalhantes que estão mostrados na Figura 4.11. Observase que, na base do muro, há uma concentração de deformações cisalhantes e que o processo, como observado por ROSCOE (1970), se atenua em direção ao topo da estrutura.

Os contornos das deformações cisalhantes também podem ser utilizados para indicar a formação da superfície hipotética de ruptura . A linha tracejada da Figura 4.11, é obtida pelos pontos de máxima curvatura dos contornos das deformações cisalhantes. Ela é um indicativo de formação incipiente de uma possível superfície de ruptura.

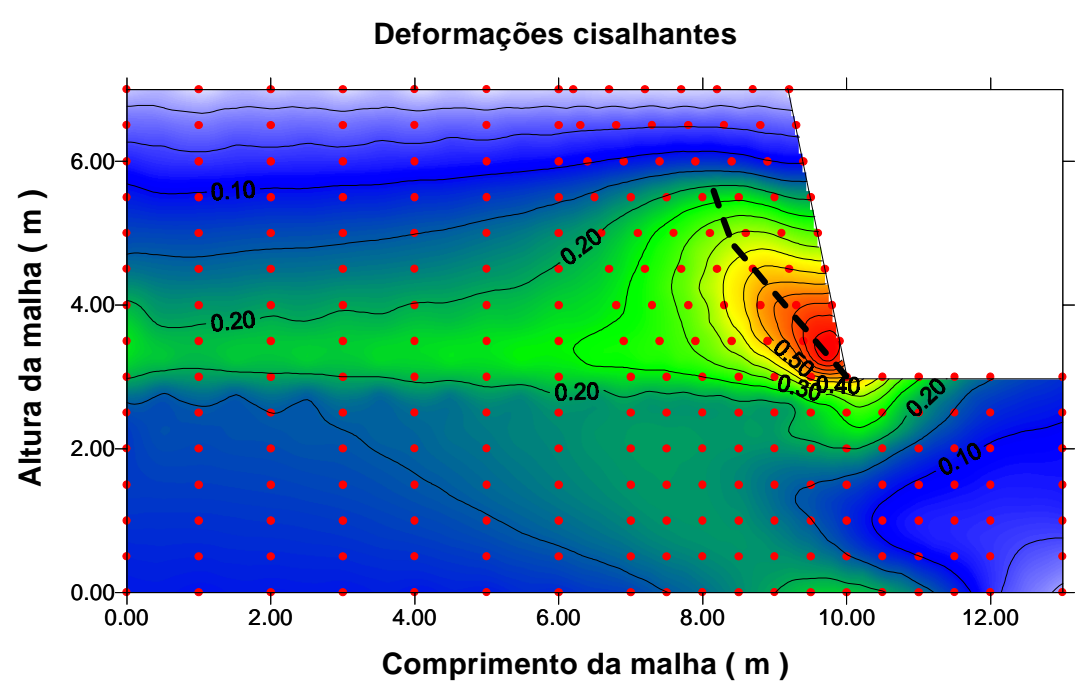

FIGURA 4.11-Deformações cisalhantes máximas atuantes na estrutura de contenção.

\subsubsection{Resultados das distribuições das forças de tração nas inclusões}

A Figura 4.12 apresenta as distribuições das forças de tração máximas obtidas numericamente para cada camada de reforço do protótipo. Unindo-se os pontos de máxima tração, em cada camada de reforço, obtém-se a superfície hipotética de ruptura. 
Comparando-se os resultados mostrados nas Figuras 4.11 e 4.12 nota-se uma boa concordância na localização da superfície de ruptura indicada pelos contornos de deformações cisalhantes e pelas forças de tração máximas nas inclusões.

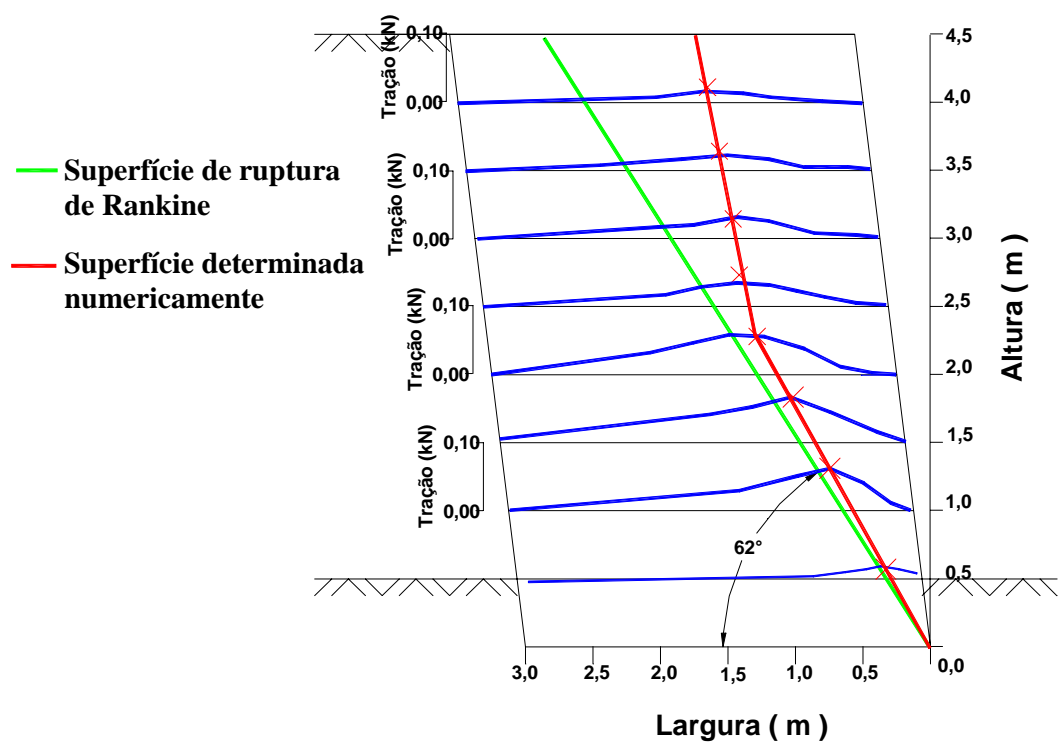

FIGURA 4.12 - Distribuição das forças de tração e posição da superfície de ruptura.

A distribuição das forças de tração estão representadas em cada camada de reforço e, ao lado de cada camada, encontra-se uma escala que mostra a magnitude das forças de tração ao longo do seu comprimento. Nota-se que os valores numéricos são baixos e que as forças de tração máximas se concentram entre 1,0 e 2,5m de altura e não nas partes mais baixas como era de se esperar. Isto se deve ao efeito do atrito entre o maciço reforçado e a fundação reduzindo, com isto, a força de tração próximo à fundação.

\subsection{Análises paramétricas}

Análises paramétricas foram realizadas para verificar as influências do tipo de solo, do tipo de inclusão e dos arranjos das inclusões no comportamento de estruturas de contenção reforçadas. Os parâmetros do solo da fundação, do silte e da argila utilizados nas análises paramétricas foram obtidos do trabalho de BOSCARDIN et al.(1990) e estão apresentados na Tabela 4.1. 
TABELA 4.1 - Parâmetros do modelo hiperbólico dos solos usados na simulação.

\begin{tabular}{|l|c|c|c|c|c|c|c|c|c|c|}
\hline Parâmetros & $\boldsymbol{\gamma}\left(\mathbf{k N} / \mathbf{m}^{3}\right)$ & $\mathbf{K}$ & $\mathbf{n}$ & $\mathbf{R f}$ & $\mathbf{K b}$ & $\mathbf{m}$ & $\mathbf{c ~ ( k P a )}$ & $\boldsymbol{\phi}\left(^{\mathbf{9}}\right)$ & $\mathbf{K o}$ & $\mathbf{K u r}$ \\
\hline Odessa & 17,8 & 963 & 0,42 & 1,00 & 212 & 0,00 & 9,7 & 34 & 0,44 & 1445 \\
\hline Silte & 20,4 & 200 & 0,60 & 0,70 & 100 & 0,50 & 2,4 & 35 & 0,43 & 300 \\
\hline Argila & 16,5 & 120 & 0,45 & 1,00 & 50 & 0,60 & 62,0 & 15 & 0,74 & 180 \\
\hline Fundaçãa & 20,4 & 600 & 0,25 & 0,7 & 450 & 0,00 & 0,0 & 36 & 0,41 & 900 \\
\hline
\end{tabular}

A Tabela 4.2 apresenta um resumo das análises paramétricas realizadas.

TABELA 4.2 - Análises paramétricas.

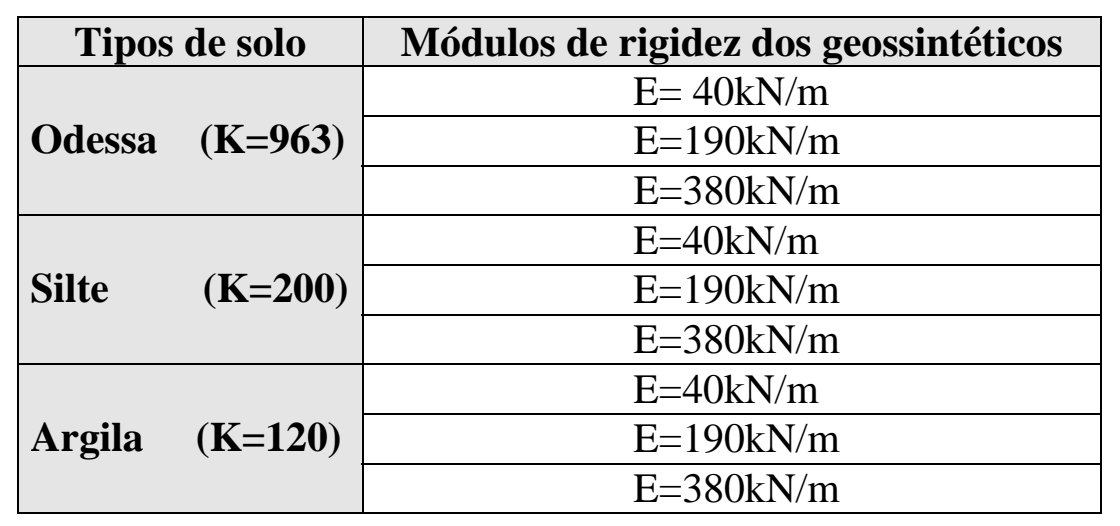

\subsubsection{Efeito do tipo de solo}

A Figura 4.13 mostra os resultados obtidos das análises paramétricas realizadas para averiguar o efeito do tipo de solo no comportamento da estrutura de contenção de altura igual ao protótipo construído. Para isto utilizou-se o arranjo do protótipo e o geossintético de menor rigidez.

Observa-se que o deslocamento horizontal máximo calculado para o silte atingiu cerca de $170 \mathrm{~mm}$, enquanto o deslocamento máximo da estrutura para a areia de Nova Odessa atingiu apenas $20 \mathrm{~mm}$. A grande diferença de rigidez do solo é a principal razão para que a estrutura construída com a areia tenha apresentado deslocamentos tão menores do que a construída com o silte. A estrutura executada com argila apresentou deslocamento horizontal máximo com cerca de $35 \mathrm{~mm}$, isto é, bem menor que o silte. Embora tenha o menor parâmetro K, a argila apresenta, ao 
contrário do silte, $62 \mathrm{kPa}$ de coesão drenada. Isto contribuiu para que a estrutura em argila apresentasse menores deslocamentos do que a executada com o silte.

Do exposto é possível afirmar que para as estruturas estudadas, feitas com solos não coesivos, um aumento do parâmetro $\mathrm{K}$ induzem reduções nos deslocamentos horizontais. Por outro lado, a estrutura executada com argila apresentou deslocamentos menores do que a feita com silte, apesar de possuir parâmetro K menor. Possivelmente, isto é devido ao efeito da coesão.

\subsubsection{Efeito da rigidez da inclusão}

Quanto à influência da rigidez da inclusão observa-se na Figura 4.13 que o estudo feito com o silte, com rigidez da inclusão igual a $40 \mathrm{kN} / \mathrm{m}$, apresenta deslocamento horizontal máximo em torno de $170 \mathrm{~mm}$, enquanto que para a inclusão de $380 \mathrm{kN} / \mathrm{m}$ este deslocamento atingiu $148 \mathrm{~mm}$. Nota-se, portanto, que com um aumento da rigidez da inclusão de 9,5 vezes os deslocamentos máximos reduziramse em apenas $15 \%$. Por outro lado, a estrutura contruída com a areia de Nova Odessa e com rigidez da inclusão igual a $40 \mathrm{kN} / \mathrm{m}$ e $380 \mathrm{kN} / \mathrm{m}$ apresentou deslocamento horizontal máximo em torno de $20 \mathrm{~mm}$ e $19 \mathrm{~mm}$, respectivamente. Observa-se também uma redução muito pequena de deslocamentos, de cerca de 4,7\% apenas. Finalmente, o muro feito com a argila e com rigidez da inclusão igual a 40kN/m, apresentou o deslocamento horizontal máximo de cerca de $35 \mathrm{~mm}$, enquanto que com a inclusão de $380 \mathrm{kN} / \mathrm{m}$ este deslocamento atingiu $31 \mathrm{~mm}$. Observa-se uma redução de deslocamentos de $16 \%$.

Do exposto pode-se depreender que as estruturas executadas com silte e argila, por possuírem parâmetros $\mathrm{K}$ menores, são mais sensíveis à variação da rigidez da inclusão do que o muro construído com a areia de Nova Odessa.

A compatibilidade de deslocamentos entre o solo e o reforço é uma das possíveis razões que pode ser utilizada para explicar o motivo de reforços mais rígidos provocarem menores deslocamentos. Os reforços mais rígidos precisam sofrer menores deslocamentos para mobilizar maiores forças de tração. 


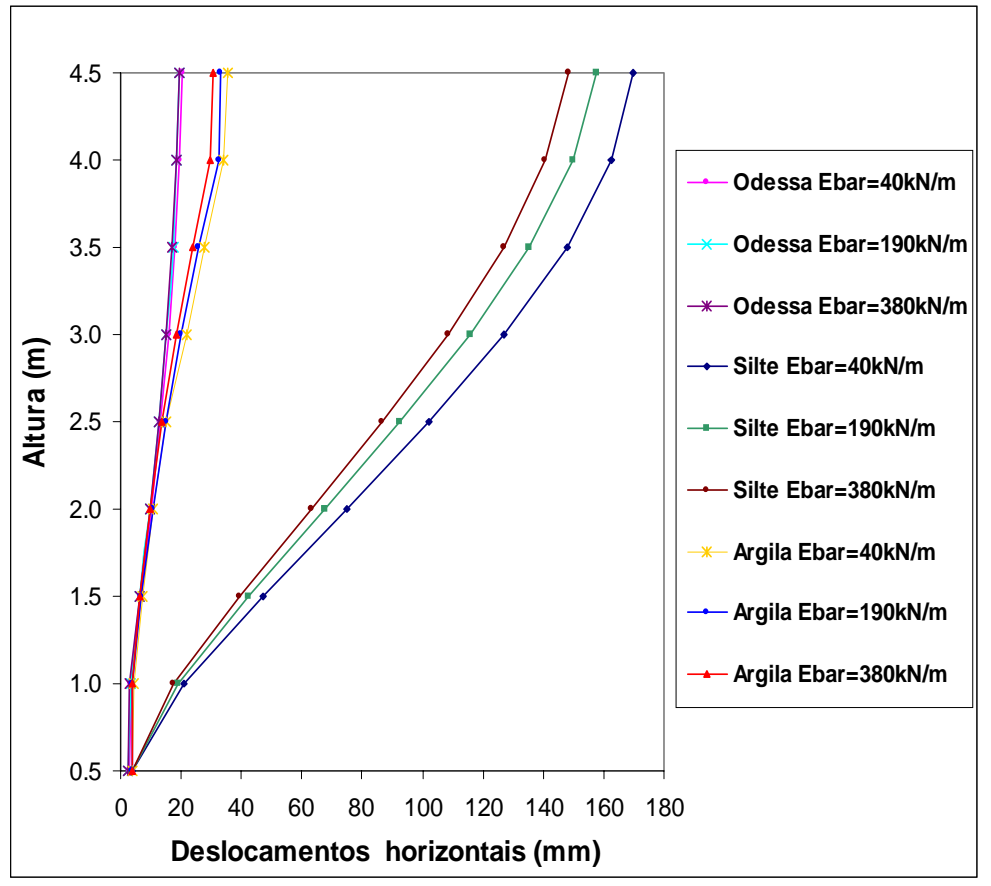

FIGURA 4.13 - Deslocamentos horizontais para alguns tipos de solos e inclusões.

Comparando-se o efeito do tipo de solo e da inclusão, conclui-se que o tipo de solo é o fator que mais influencia nos deslocamentos horizontais de uma estrutura de contenção reforçada com geossintético. As análises paramétricas realizadas por HELMANY et al. (1999) confirmaram esta conclusão.

\subsubsection{Efeito do tipo de arranjo}

Os três arranjos simulados estão esquematizados na Figura 4.14. O solo utilizado nestas simulações foi a areia de Nova Odessa e o geossintético empregado apresenta rigidez de $40 \mathrm{kN} / \mathrm{m}$. Os arranjos 1 e 2 apresentam espaçamentos verticais e comprimentos das inclusões constantes ao longo de toda a altura do muro. No arranjo 3 o espaçamento da metade superior é o dobro do da metade inferior.
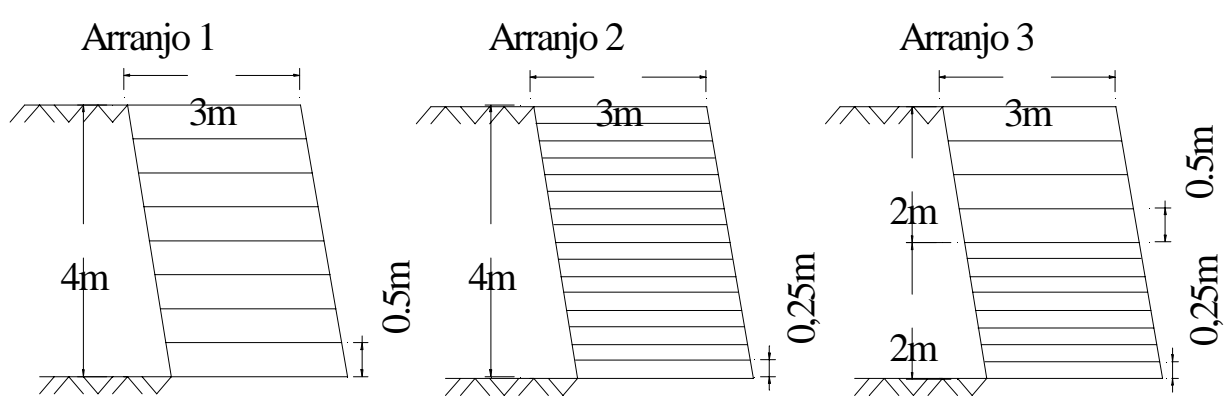

FIGURA 4.14 - Tipos de arranjos que serão analisados. 
As estruturas dispostas segundo os arranjos 1, 2 e 3 apresentaram deslocamentos horizontais máximos com cerca de $60 \mathrm{~mm}, 41 \mathrm{~mm}$ e $47 \mathrm{~mm}$, respectivamente (Figura 4.15). Os deslocamentos dos arranjos 2 e 3 são menores, porque possuem maior densidade de reforço, consequentemente, menores forças de tração serão mobilizadas em cada reforço.

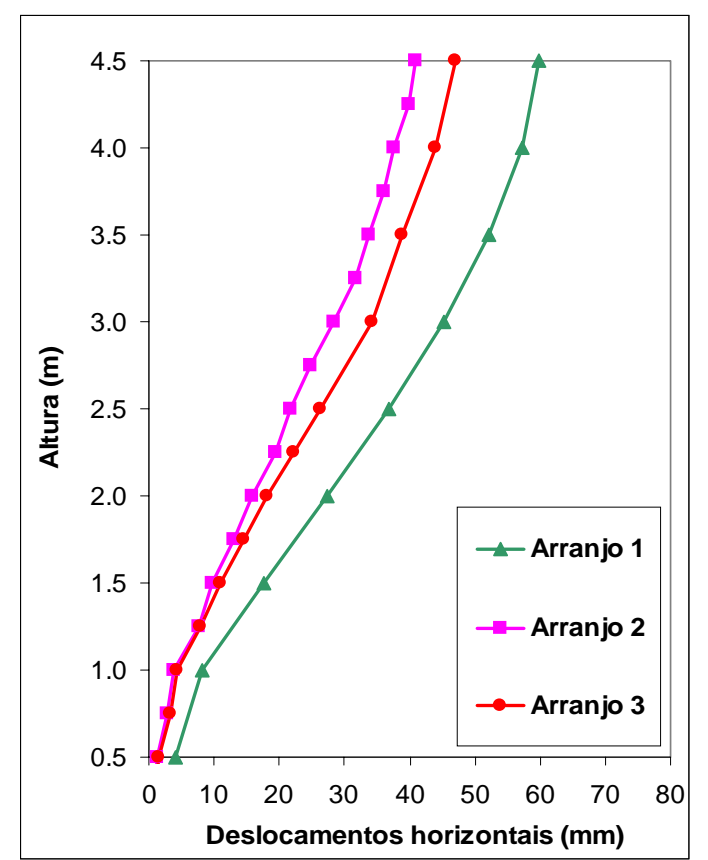

FIGURA 4.15 - Deslocamentos horizontais para diferentes arranjos.

O arranjo 3 apresentou deslocamento horizontal máximo $15 \%$ maior do que o arranjo 2. Ou seja, os deslocamentos permaneceram com a mesma ordem de grandeza, porém houve cerca de $25 \%$ de redução no volume de inclusão. Considerando que o deslocamento do arranjo 3 satisfaz os requisitos de utilização da estrutura, este arranjo pode ser considerado a melhor opção custo-benefício dentre as três analisadas.

\subsubsection{Forças de tração máximas nas inclusões}

Através das análises paramétricas foram calculados os valores das forças de tração máximas nas inclusões no maciço reforçado, para alguns tipos de solo e inclusões (Figura 4.16).

Quanto à influência dos tipos de solo, observa-se que os solos mais rígidos, como o de Nova Odessa, mobilizam menores forças de tração nas inclusões do que o 
silte e a argila, que são menos rígidos. Isto, como já mencionado, pode ser um indicativo de que estruturas de contenção executadas com maciços mais rígidos, por possuírem maior resistência ao cisalhamento, precisam mobilizar menores forças das inclusões para garantir o equilíbrio do sistema.

Com relação ao tipo de inclusão, nota-se que as mais rígidas mobilizam maiores forças de tração do que as menos rígidas. Isto se deve ao fato das inclusões mais rígidas precisarem de menores deslocamentos para atingirem maiores tensões de tração.

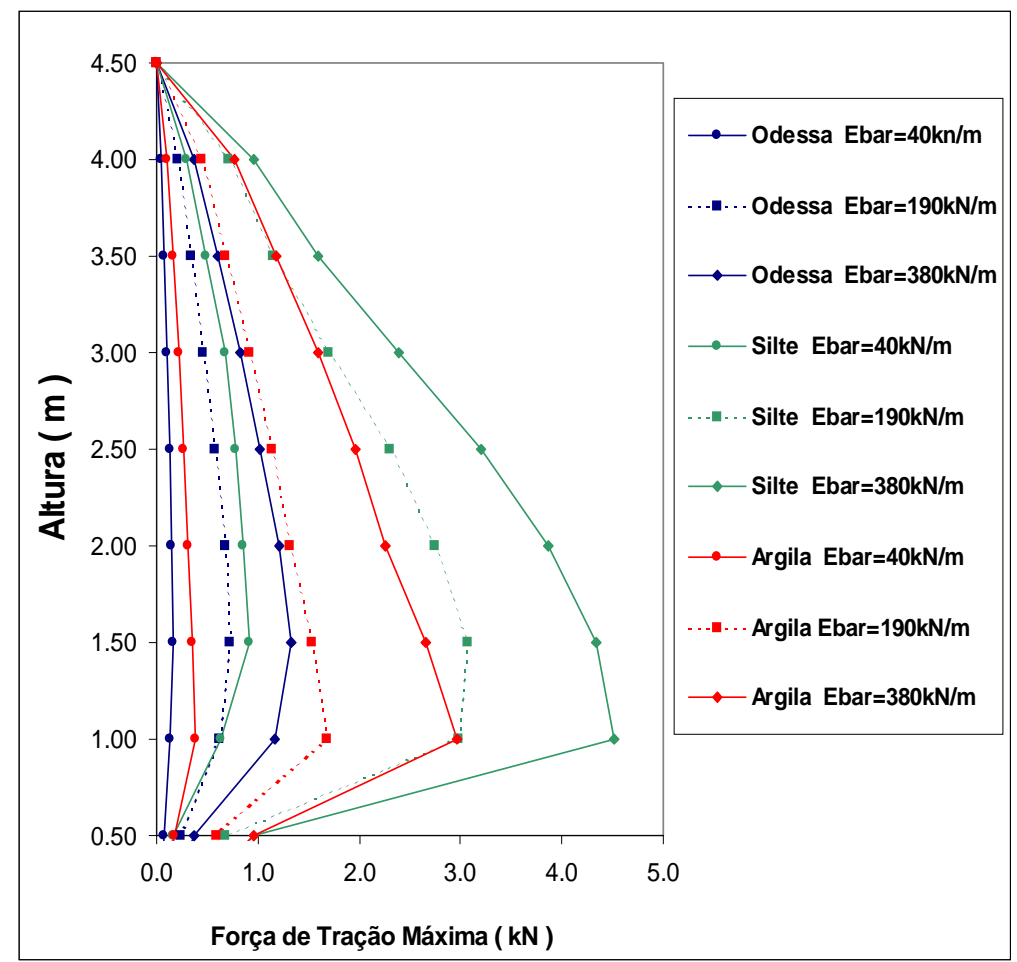

FIGURA 4.16 - Forças de tração máximas ao longo da altura da estrutura.

As análises convencionais admitem uma distribuição triangular das forças de tração nas inclusões ao longo do maciço reforçado. Vê-se que, à exceção de pontos próximos à base do muro em que as forças de tração sofre influência da fundação, esta hipótese se ajusta muito bem com os resultados da simulação. A redução das forças de tração na base da estrutura de contenção tem sido creditada à rugosidade da superfície de apoio. Este efeito tem sido observado por vários autores entre eles BATHURST et al. (1995), THAMM \& LESNIEWSKA (1990), SIMAC et al. (1990) em trabalhos experimentais e por ADIB et al. (1990), CHALATURNYK \& SCOTT (1990), ROWE \& HO (1992) que fizeram simulações numéricas. 


\subsubsection{Localização da superfície de ruptura}

É importante observar a influência dos tipos de solo e de inclusões na localização da superfície hipotética de ruptura (Figura 4.17). Nota-se que para solos e inclusões mais rígidas a superfície hipotética de ruptura se aproxima mais da face, enquanto para solos e inclusões menos rígidos ela se localiza mais para o interior do maciço. Além disto, estes resultados sugerem uma distribuição mais bilinear, concordante com o clássico mecanismo para inclusões metálicas utilizado pela terra armada.

ADIB et al. (1990) demonstraram, também, através de análises numéricas que a rigidez do reforço afeta a localização da superfície hipotética de ruptura. $O$ aumento da rigidez do reforço faz com que esta superfície fique mais próxima da face. ZORNBERG et al. (1998), no entanto, realizaram ensaios com modelos reduzidos em centrífuga variando a rigidez do solo e das inclusões e observaram que a localização das superfícies de ruptura são aproximadamente a mesma, independente dos casos estudados.
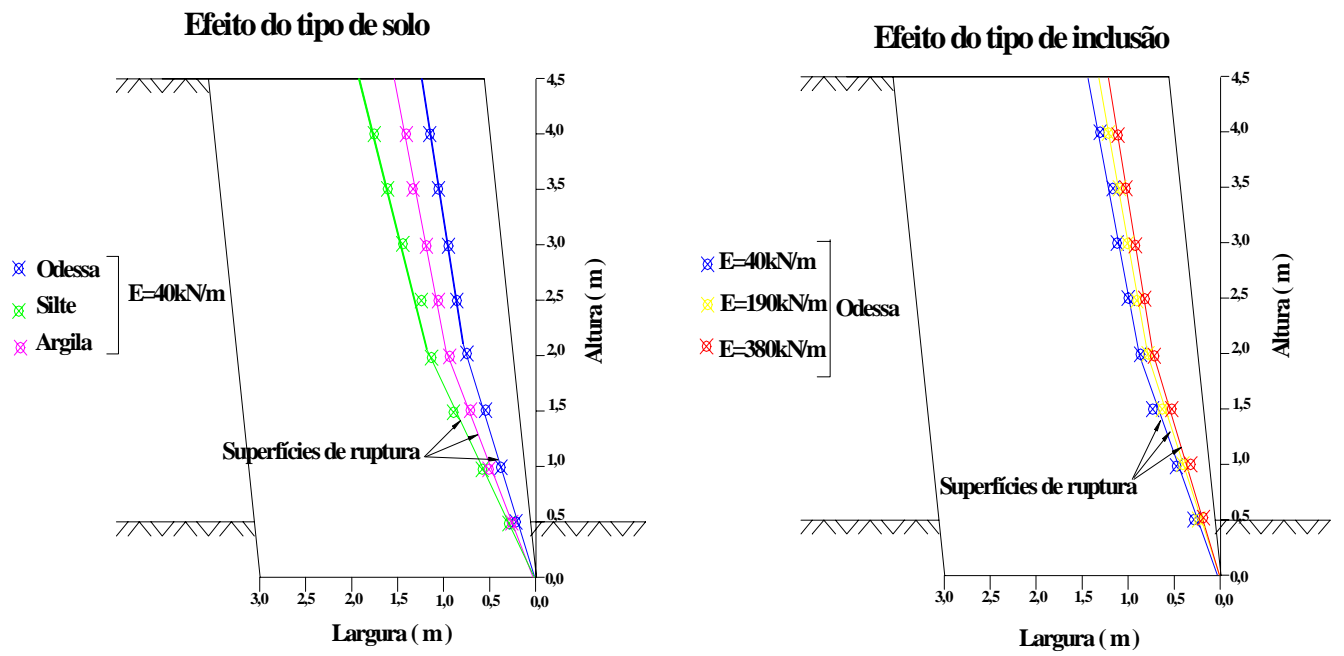

FIGURA 4.17 - Localizações das superfícies hipotéticas de ruptura para alguns tipos de solos e inclusões.

\subsection{Casos de obras instrumentadas}

É importante comparar os deslocamentos ocorridos no protótipo com os medidos em outras estruturas de contenção descritas na literatura. A Tabela 4.3 
apresenta deslocamentos registrados em algumas estruturas de contenção, juntamente com as características construtivas de cada uma. Os deslocamentos foram previstos segundo a metodologia descrita por CHRISTOPHER et al. (1990). Onde: $\delta$ é o deslocamento horizontal e H é a altura da estrutura.

TABELA 4.3 - Deslocamentos horizontais publicados na literatura.

\begin{tabular}{|c|c|c|c|c|c|c|c|c|}
\hline Autores & Inclusões & Solo & $\begin{array}{c}\text { Espaçament } \\
\text { o vertical } \\
\left(\mathbf{S}_{\mathbf{v}}\right) \\
\end{array}$ & $\begin{array}{l}\text { Tipo de } \\
\text { face }\end{array}$ & $\begin{array}{c}\text { H (altura } \\
\text { da } \\
\text { estrutura) }\end{array}$ & L/H & $\begin{array}{c}\delta / \mathrm{H} \\
\text { medido }\end{array}$ & $\begin{array}{c}\delta / H \\
\text { previsto }\end{array}$ \\
\hline $\begin{array}{c}\text { Pedroso } \\
\text { (2000) }\end{array}$ & $\begin{array}{l}\text { Geotêxtil } \\
\text { Não tecido }\end{array}$ & $\begin{array}{c}\text { Areia fina } \\
\phi=34^{\circ} \mathrm{c}=9,7 \mathrm{kPa} \\
\gamma=17,8 \mathrm{kN} / \mathrm{m}\end{array}$ & $\begin{array}{l}\text { Constante } \\
\mathrm{S}_{\mathrm{v}}=50 \mathrm{~cm}\end{array}$ & $\begin{array}{c}\text { Envelo- } \\
\text { pado }\end{array}$ & $4,00 \mathrm{~m}$ & 0,75 & $0,90 \%$ & $1,20 \%$ \\
\hline $\begin{array}{c}\text { Tsukada } \\
\text { et al. } \\
\text { (1998) } \\
\end{array}$ & $\begin{array}{c}\text { Geotêxtil } \\
\text { Tecido }\end{array}$ & $\begin{array}{c}\text { Arenoso } \\
\phi=29^{\circ}, c=0 \\
\gamma=18,6 \mathrm{kN} / \mathrm{m}^{3}\end{array}$ & $\begin{array}{c}\text { Constante } \\
50 \mathrm{~cm} \\
\end{array}$ & Alvenaria & $8,00 \mathrm{~m}$ & 0,75 & $0,90 \%$ & $1,24 \%$ \\
\hline $\begin{array}{c}\text { Ehrlich } \\
\text { et al. } \\
(1994) \\
\end{array}$ & $\begin{array}{l}\text { Geotêxtil } \\
\text { Não-tecido }\end{array}$ & $\begin{array}{l}\text { Argilo-arenoso } \\
\phi=33^{\circ} \mathrm{c}=50 \mathrm{kPa} \\
\gamma=15,6 \mathrm{kN} / \mathrm{m}^{3}\end{array}$ & $\begin{array}{l}\text { Constante } \\
30 \mathrm{~cm} \\
\end{array}$ & $\begin{array}{l}\text { Envelo- } \\
\text { pado }\end{array}$ & $4,00 \mathrm{~m}$ & 0,70 & $0,20 \%$ & $1,33 \%$ \\
\hline $\begin{array}{c}\text { Simac et } \\
\text { al. (1990) }\end{array}$ & Geogrelha & $\begin{array}{c}\text { Areia fina } \\
\phi=39^{\circ}, c=0 \\
\gamma=20,5 \mathrm{kN} / \mathrm{m}^{3}\end{array}$ & $\begin{array}{c}\text { Variável } \\
\mathrm{S}_{\mathrm{v}}=60 \mathrm{~cm} \mathrm{e} \\
\mathrm{S}_{\mathrm{v}}=80 \mathrm{~cm} \\
\end{array}$ & Alvenaria & $6,00 \mathrm{~m}$ & 0,72 & $0,60 \%$ & $1,31 \%$ \\
\hline $\begin{array}{l}\text { Holtz et } \\
\text { al. (1991) }\end{array}$ & $\begin{array}{l}\text { Geotêxtil } \\
\text { tecido } \\
\text { (4 tipos) }\end{array}$ & $\begin{array}{c}\text { Areia } \\
\phi=36^{\circ}, c=0 \\
\gamma=20,4 \mathrm{kN} / \mathrm{m}^{3}\end{array}$ & $\begin{array}{l}\text { Constante } \\
38 \mathrm{~cm} \\
\end{array}$ & $\begin{array}{c}\text { Envelo- } \\
\text { pado }\end{array}$ & $12,60 \mathrm{~m}$ & 0,77 & $0,60 \%$ & $1,03 \%$ \\
\hline $\begin{array}{c}\text { Marques } \\
\text { (1994) }\end{array}$ & $\begin{array}{c}\text { Geotêxtil } \\
\text { Não-tecido }\end{array}$ & $\begin{array}{c}\text { Arenoso } \\
\phi=37^{\circ}, c=8 \mathrm{kPa} \\
\gamma=17 \mathrm{kN} / \mathrm{m}^{3}\end{array}$ & $\begin{array}{l}\text { Constante } \\
\mathrm{S}_{\mathrm{v}}=55 \mathrm{~cm}\end{array}$ & Alvenaria & $2,00 \mathrm{~m}$ & 1,00 & $0,90 \%$ & $0,96 \%$ \\
\hline $\begin{array}{c}\text { Ribeiro } \\
\text { (1999) }\end{array}$ & $\begin{array}{c}\text { Geotêxtil } \\
\text { Não-tecido }\end{array}$ & $\begin{array}{c}\text { Areno-argiloso } \\
\phi=35^{\circ} \mathrm{c}=20 \mathrm{kPa} \\
\gamma=20 \mathrm{kN} / \mathrm{m}^{3}\end{array}$ & $\begin{array}{c}\text { Variável } \\
S_{v}=30 \mathrm{~cm} \mathrm{e} \\
S_{v}=60 \mathrm{~cm}\end{array}$ & $\begin{array}{l}\text { Concreto } \\
\text { Projetado }\end{array}$ & $7,00 \mathrm{~m}$ & 0,70 & $0,33 \%$ & $1,33 \%$ \\
\hline $\begin{array}{c}\text { Bathurst } \\
\text { et al. } \\
\text { (1995) }\end{array}$ & Geogrelha & $\begin{array}{c}\text { Areia Grossa } \\
\phi=53^{\circ}, \quad c=0 \\
\gamma=17,8 \mathrm{kN} / \mathrm{m}\end{array}$ & $\begin{array}{l}\text { Constante } \\
\mathrm{S}_{\mathrm{v}}=75 \mathrm{~cm}\end{array}$ & $\begin{array}{l}\text { Painel de } \\
\text { Concreto }\end{array}$ & $3,00 \mathrm{~m}$ & 1,00 & $0,40 \%$ & 0,96 \\
\hline
\end{tabular}

As Figuras 4.18 e 4.19 foram elaboradas a partir dos dados da Tabela 4.3. Pode ser observado, em ambas as figuras, que os pontos se localizaram abaixo da reta de $45^{\circ}$, demonstrando que as deformações previstas são sempre maiores que as medidas. Isto permite concluir que este método de previsão de deslocamentos mostrou-se conservador para os casos selecionados.

As estruturas construídas com geogrelhas, geotêxteis tecidos e geotêxteis não tecidos apresentaram deformações da ordem de 0,4; 0,6 e 0,9\%, respectivamente. Isto mostra que as estruturas construídas com geossintéticos mais rígidos, como 
geogrelhas e geotêxteis tecido, caracterizaram-se por deformações horizontais menores do que os geossintéticos menos rígidos, como os geotêxteis não tecidos (Figura 4.18)

As deformações horizontais máximas medidas no protótipo foram de $0,90 \%$. O mesmo nível de deformação obtido por MARQUES (1994) e por TSUKADA et al. (1998). Estes autores usaram solos não coesivos. No entanto, EHRLICH et al. (1994) e RIBEIRO et al. (1999) usaram solos coesivos e registraram deformações de cerca de $0,20 \%$ e $0,33 \%$, respectivamente, o que é um indicativo da grande influência do tipo de solo nos deslocamentos das estruturas de contenção (Figura 4.19).

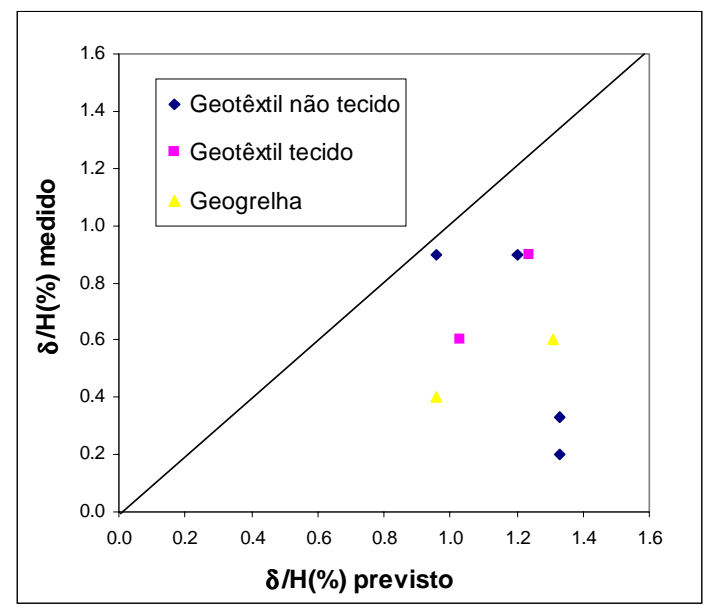

FIGURA 4.18 - Efeito do tipo de inclusão em obras instrumentadas.

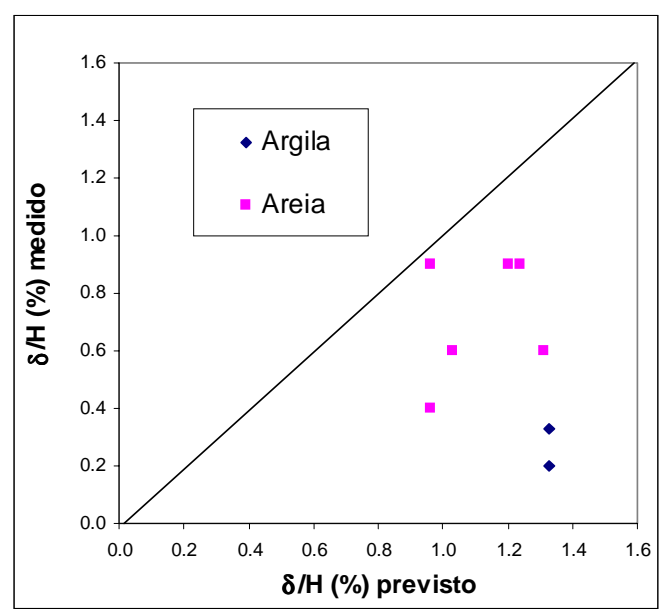

FIGURA - 4.19 - Efeito do tipo de solo em obras instrumentadas.

Comparando-se as análises paramétricas realizadas e os dados de obras instrumentadas observou-se uma boa concordância de resultados. As análises paramétricas mostram que para solos não coesivos o aumento da rigidez do solo provoca uma diminuição dos deslocamentos horizontais. Isto é confirmado pelos resultados de obras instrumentadas. Os solos coesivos possuem parâmetros K menores que os não coesivos, no entanto, apresentam deslocamentos menores que os solos não coesivos devido, possivelmente, à coesão. Estas observações estão concordantes com os resultados das análises paramétricas e com os resultados de obras instrumentadas. 


\section{CONCLUSÕES E RECOMENDAÇÕES PARA PESQUISAS FUTURAS}

\subsection{Conclusões}

Do exposto neste trabalho pode-se concluir com relação ao protótipo que:

a) Os deslocamentos horizontais medidos no protótipo estão coerentes com os resultados da simulação numérica e com os resultados de obras instrumentadas descritos na literatura. No entanto, foram registrados deslocamentos crescentes com o tempo após a construção do protótipo, indicando além de uma possível fluência do geotêxtil o efeito de cargas externas que foram aplicadas ao maciço reforçado. Este efeito se estabilizou após 120 dias.

b) Como esperado, os deslocamentos horizontais e verticais medidos próximo à face foram maiores que os medidos fora da face, indicando a formação de uma superfície hipotética de ruptura.

Os resultados obtidos das análises paramétricas permitem concluir que:

a) O tipo de solo é o fator que mais influencia na magnitude dos deslocamentos horizontais das estruturas reforçadas com geossintéticos. 
b) A influência da rigidez da inclusão é mais significativa em solos não coesivos, menos resistentes. $\mathrm{O}$ aumento da rigidez da inclusão, em estruturas de contenção executadas com solos pouco resistentes, resultará numa redução significativa dos deslocamentos horizontais. No entanto, o aumento da rigidez da inclusão, em estruturas executadas com solos resistentes, não resultará numa redução significativa dos deslocamentos horizontais;

c) Os arranjos mais eficientes são aqueles que garantem deslocamentos pequenos e uma boa economia de geotêxtil. Isto pode ser conseguido quando coloca-se um espaçamento vertical menor na parte inferior da estrutura de contenção e um espaçamento maior na parte superior;

d) O tipo de solo, a rigidez da inclusão e a fundação afetam os valores das forças de tração máximas mobilizadas nas inclusões ao longo da profundidade do maciço reforçado. Solos mais rígidos mobilizam menores forças de tração nas inclusões do que solos menos rígidos. As inclusões mais rígidas mobilizam maiores forças de tração do que inclusões menos rígidas. O tipo de solo é também o fator mais importante na mobilização das forças de tração máximas nas inclusões. Nas proximidades da fundação as forças de tração diminuem devido ao atrito entre o maciço reforçado e a fundação;

e) A localização da superfície hipotética de ruptura pode variar com o tipo de solo e inclusão. Para solos e inclusões mais rígidos a superfície hipotética de ruptura se aproxima da face, enquanto os solos e inclusões menos rígidos se localizam mais distantes da face. Além disto, os resultados sugerem uma distribuição bilinear, concordando com o clássico mecanismo para inclusões metálicas utilizado pela terra armada. 


\subsection{Recomendações para Pesquisas Futuras}

Para as pesquisas futuras que visarem dar continuação aos estudos de estruturas em solos reforçados são sugeridos alguns aspectos:

a) Observa-se a necessidade de ampliar o conhecimento do meio técnico a respeito da influência do tipo de solo nos deslocamentos horizontais e verticais, nas forças de tração mobilizadas nas inclusões, nas formas e localizações das superfícies hipotéticas de ruptura das estruturas reforçadas com geossintéticos. Isto poderia ser feito construindo e instrumentando mais protótipos, em escala real, executados com outros tipos de solo.

b) Seria de grande importância, realizar um maior número de simulações numéricas utilizando-se outros programas que corrigiriam, automaticamente, a malha de elementos finitos com o lançamento das camadas.

c) A fluência do geotêxtil e/ou do solo, nos deslocamentos horizontais e verticais das estruturas em solo reforçado, é um fator muito importante que deve ser melhor estudado.

d) Seria importante, também, aumentar a experiência a respeito do efeito da face nos deslocamentos, tensões e forças nas inclusões da estrutura em solo reforçado. 


\section{REFERÊNCIAS BIBLIOGRÁFICAS}

ADIB, M.; MITCHELL, J.K.; CHRISTOPHER, B. (1990). Finite element modelling of reinforced soil walls and embankments. Design and Performance of Earth retaining structures, Geotechnical Special Publication, ASCE, n. 25, p. 409-423.

AZEVEDO, R.F., ZORNBERG, J.G., NOGUEIRA, C.L. (1992). Utilização dos elementos finitos no cálculo de estruturas de solos reforçados. In: Seminário sobre aplicações de geossintéticos em geotecnia, Geossintéticos 92, Brasília, p.122-128.

BATHURST, R. J.; BENJAMIN, D.J.; JARRET, P.M. (1988). Laboratory study of geogrid reinforced soil walls. Geotechnical Special Publication, ASCE, n.18, p.178192.

BOLTON, M.D.; PANG, P.L.R. (1982). Collapse limit states of reinforced earth retaining walls. Geotechnique, v.32, n. 4, p 349-367.

BOSCARDIN, M.D.; SELIG, E.T.; LIN, R.; YANG, G. (1990). Hyperbolic Parameters for Compacted Soils. Journal of Geotechnical Engineering Division, ASCE, v. 116, n. 1, p. 88-104. 
BOULANGER, R. W.; BRAY, J.D.; CHEW, S.H.; SEED, R.B.; MITCHELL, J.K.; DUNCAN, J.M. (1991). A finite element analysis program for evaluation of soil structure interaction and compaction effects. Version 1.0. Report No. UCB/GT/9102, April, Department of Civil Engineering, University of California at Berkeley, $176 \mathrm{p}$.

BROMS, B. (1971). Lateral earth pressures due to compaction of cohesionless soils. In: Proceedings of the $4^{\text {th }}$ Conference on Soil Mechanics, Budapest, p.373-384

CAZUFFI et al. (1994). Outdoor and UV-B laboratory weqthering resistance of geosynthetics. In: Geotextiles, Geomembranes and Related Products, $5^{\text {th }}$. Prooceedings. Singapure. v.3, p. 1195-1198.

CHALATURNYK, R.J.; SCOTT, J.D. (1990). Stresses and deformations in a reinforced soil slope. Canadian Geotechnical Journal, v. 27, p. 224-232.

CHANG, J. C.; FORSYTH, R. F. (1977). Finite element analysis and design of reinforced earth wall. Journal of the Geotechnical Engineering Division, ASCE, v. 103, n. 7, p. 711-724.

CHRISTOPHER, B.R.; GILL, S.A.; GIROUD, J.P.; MITCHELL, J.; SCHLOSSER, F.; DUNNICLIFF, J. (1990). Design and construction guidelines for reinforced soil structures. Federal Highway Administration, U.S. Department of Transportation, Report No. FHWA-RD-89-043, 285p.

DUNCAN, J.M.; CHANG, C. S. (1970). Nonlinear analysis of stress and strain in soils. Journal of the Soil Mechanics and Foundation Division, v. 35, n.5, p. 10531068.

DUNCAN, J.M.; SEED, R.B. (1986). Compaction-induced earth pressures under $\mathrm{K}_{0^{-}}$ conditions. Journal of Geotechnical Engineering, ASCE, v. 112, n.1, p.1-22. 
EHRLICH, M.; MITCHELL, J.K. (1994). Working stress design method for reinforced soil walls. Journal of Geotechnical Engineering, ASCE, v.120,n.4, p. 625645.

EHRLICH, M.; VIANNA, A.J.D.; FUSARO, F. (1994). Comportamento de um muro de solo reforçado. In: X Congresso Brasileiro de Mecânica dos solos e Engenharia de Fundações, Foz do Iguaçu, v.3, p. 819-824.

GIAGHETI, H. L. (1987). Aplicabilidade de modelos elásticos para previsão do comportamento tensão-deformação de um solo compactado. São Carlos. 162p. Dissertação (Mestrado) - Escola de Engenharia de São Carlos, Universidade de São Paulo.

HELMANY, S.M.B.; REARDON, G.; WU, J.T.H. (1999). Effects of backfil on the performance of GRS retaining walls. Geotextiles and Geomembranes, v. 17, p. 1-16.

HO, S.K.; ROWE, R. K. (1996). Effect of wall geometry on the behaviour of reinforced soil walls. Geotextiles and Geomembranes, v. 14, p. 521-541.

HOLTZ; R.D.; ALLEN, T.M.; CHRISTOPHER, B.R. (1991). Displacement of a $12,6 \mathrm{~m}$ high geotextile-reinforced wall. In: Proceedings of the $10^{\text {th }}$ European Conference on Soil Mechanics and Foundation Engineering, Florence, p.725-728.

INGOLD, T.S. (1979). The effects of compaction on retaining walls. Geotechnique, v.29, n.3, p.265-285.

JABER, M. B. (1989). Behavior of reinforced soil walls in centrifuge tests, Ph. D. thesis, University of California at Berkeley 
JEWELL, R. A.; JONES, C. J. (1981). Reinforcement of clay soils and waste materials using grids. In: International Conference on Soil Mechanics and Foundation Enginnering, 10, Stockholm, Sweden, 1981, v. 2, p. 701-706.

JEWELL, R.A. (1991). Application of revised design charts for steep reinforced slopes. Geotextiles and Geomembranes, v. 10, p. 203-233.

JONES, C.J.F.P. (1990). Construction influences on the performance of reinforced soil structures. In: Performance of reinforced soil structures, p. 97-116.

KARPURAPU, R.; BATHURST, R.J. (1992). Numerical investigation of controlled yielding of soil-retaining wall structures. Geotextiles and Geomembranes, v. 11, p. 115-131.

KARPURAPU, R.; BATHURST, R.J. (1995). Behaviour of geoseosynthetic reinforced soil retaining walls using the finite element method. Computers and Geotechnics, n.17, p.279-299.

KOERNER, R. (1994). Designing with geosynthetics. Englewood Cliffs, New Jersey, Prentice Hall, $3^{\text {th }}$ Ed.

LANZ, D.; PALMEIRA, E.M. (1994). Distribuição de tensões e deformações em estruturas de arrimo reforçadas com geossintéticos. In: X Congresso Brasileiro de Mecânica dos solos e Engenharia de Fundações, Foz do Iguaçu, v.3, p. 833-840.

LESHCHINSKY, D.; BOEDEKER, R.H. (1989). Geosynthetic reinforced soil structures. Journal of the Geotechnical Engineering Division, v. 115, n.10, p.14591478.

LESCHINSKY, D.; PERRY, E.B. (1989). On the design of geosynthetic-reinforced walls. Geotextiles and Geomembranes, v.8, n.4, p. 311-323. 
LING, H.I.; TATSUOKA, F.;TATEYAMA, M. (1995). Simulating performance of GRS-RW by finite-element procedure. Journal of Geotechnical Engineering, v. 121, n. 4 , p. $330-340$.

MARQUES, G.L.O. (1994). Uso de geotêxteis em muros de contenção de pequeno porte. Viçosa. 126p. Dissertação (Mestrado) - Universidade Federal de Viçosa.

McGOWN, A.; ANDRAWES, K.Z.; MURRAY, R.T. (1988). Controlled yielding of the lateral boundaries of soil retaining structures. Geotechnical Special Publication, ASCE, v.18, p.193-210.

MITCHELL, J.K. (1981). Soil Inprovement: State of the Art. In: International Conference on Soil Mechanics and Foundation Engineering, Stockholm, Seweden, v. 4, p. 509-565.

MITCHELL, J.K.; VILLET, W.C.B. (1987). Reinforcement of earth slopes and embankments. National Cooperative Higway Research Program Report. n. 290

NAYLOR, D. J.; RICHARDS, H. (1978). Slipping strip analysis of reinforced earth. International Journal for Numerical and Analytical Methods in Geomechanics, v. 2, p. 343-366.

PORBAHA, A. (1998). Traces of slip surfaces in reinforced retaining structures. Soils and Foundations, v. 38, n. 1, p. 89-95.

RIBEIRO, T.S.M.T.; JUNIOR, M.C.V.; PIRES, J.V. (1999). Comportamento do aterro de solo reforçado da encosta do belvedere. In: IX Congresso Brasileiro de Geologia de Engenharia, São Pedro, 16p.

ROSCOE, K.H. (1970). The influence of strains in soil mechanics. Geotechnique, v. 20, n. 2, p. 129-170. 
ROWE, R.K; HO, S.K. (1992). Keynote Lecture: A review of the behaviour of reinforced soil walls. In: International Symposium on Earth Reinforcement Practice, Fukuoka, Balkema, v.2, p. 801-830.

ROWE, R.K.; HO, K.S. (1998). Horizontal deformation in reinforced soil walls. Canadian Geotechnical Journal, v. 35, p. 312-327.

SILVA, L.C.R. (1996). Análise do comportamento de muros reforçados em condições de trabalho. São Paulo. 202p. Dissertação (Mestrado) - Universidade de São Paulo.

SILVA, M.S. (1998). Análise pelo método dos elementos finitos de ensaios de muros de arrimo reforçados com geotêxteis. Viçosa, 93p. Dissertação (Mestrado). Universidade Federal de Viçosa.

SIMAC, M.R.; CHRISTOPHER, B.R.; BONCZKIEWICZ, C. (1990). Instrumented field performance of a $6 \mathrm{~m}$ geogrid soil wall. In: International Conference on Geotextiles, Geomembranes and Related Products, 4, The Hague, p. 53-59.

TATSUOKA, F.; TATEYAMA, M.; MURATA, O. (1989). Earth Retaining Wall With a Short Geotextile and a Rigid Facing. In: International Conference on Soil Mechanics and Foundation Engineering, 12, v. 2, p. 1311-1314.

TATSUOKA, F. (1992). Roles of facing rigidity in soil reinforcing. In: International Symposium on Earth Reinforcement Practice, Fukuoka, 1992. Balkema, v.2, p. 831870.

THAMM, B.R.; LESNIEWSKA, D. (1990). Full scale test of a geotextile reinforced soil wall. In: Performance of Reinforced Soil Structures, v.1, p. 340-341. 
TSUKADA, Y.; OCHIAI, Y.; MIYATAKI, H. (1998). Field performance test of a geosynthetic-reinforced soil wall with rigid facing. In: International Conference on Geosynthetics, 6, Atlanta, 1998, v.1, p. 577-580.

VILAR, O. M. (1979). Estudo da compressão unidirecional do sedimento moderno (solo superficial) da cidade de São Carlos. São Carlos. 110p. Dissertação (Mestrado) - Escola de Engenharia de São Carlos, Universidade de São Paulo.

ZORNBERG, J. G. (1994). Performance of geotextile reinforced soil structures. Ph.D. thesis, University of California at Berkeley, 504p.

ZORNBERG, J. G.; SITAR, N.; MITCHELL, J.K. (1998). Performance of geosynthetic reinforced slopes at failure. Journal of Geotechnical and Geoenvironmental Engineering, v. 124, n. 8, p. 670-683. 